\title{
Republic of Slovenia: 2011 Article IV Consultation-Staff Report; Public Information Notice on the Executive Board Discussion; Staff Statement; and Statement by the Executive Director for Slovenia
}

Under Article IV of the IMF's Articles of Agreement, the IMF holds bilateral discussions with members, usually every year. In the context of the 2011 Article IV consultation with Slovenia, the following documents have been released and are included in this package:

- $\quad$ The staff report for the 2011 Article IV consultation, prepared by a staff team of the IMF, following discussions that ended on March 21, 2011, with the officials of the Republic of Slovenia on economic developments and policies. Based on information available at the time of these discussions, the staff report was completed on May 4, 2011. The views expressed in the staff report are those of the staff team and do not necessarily reflect the views of the Executive Board of the IMF.

- $\quad$ A staff supplement of May 4, 2011, updating information on recent developments.

- $\quad$ A Public Information Notice (PIN) summarizing the views of the Executive Board as expressed during its May 20, 2011 discussion of the staff report that concluded the Article IV consultation.

- $\quad$ A staff statement of May 16, 2011, updating information on recent developments.

- $\quad$ A statement by the Executive Director for the Republic of Slovenia.

The policy of publication of staff reports and other documents allows for the deletion of market-sensitive information.

\author{
Copies of this report are available to the public from \\ International Monetary Fund $\bullet$ Publication Services \\ $70019^{\text {th }}$ Street, N.W. • Washington, D.C. 20431 \\ Telephone: (202) 623-7430 • Telefax: (202) 623-7201 \\ E-mail: publications@imf.org • Internet: http://www.imf.org
}

\section{International Monetary Fund Washington, D.C.}




\title{
INTERNATIONAL MONETARY FUND
}

\section{REPUBLIC OF SLOVENIA}

\section{Staff Report for the 2011 Article IV Consultation}

\author{
Prepared by the Staff Representatives for the 2011 Article IV Consultation with \\ the Republic of Slovenia
}

Approved by Juha Kähkönen and Jan Kees Martijn

May 4, 2011

\section{Executive Summary}

Background: After one of the largest GDP declines in the euro area, growth resumed only in Q2 2010 on the back of external demand. Lower potential output growth and weak domestic demand due to deleveraging are dampening growth prospects. Fiscal policy is tightening after a countercyclical stance, with the authorities committed to bringing fiscal deficit below 3 percent of GDP by 2013 mostly by freezing public wages and cutting investment. Pension reform was recently approved, but will be subjected to a referendum. Banks suffer from weak capitalization and deteriorating asset quality. Political support for reforms is weakening.

Challenges: (i) putting growth and public finances on a sustainable path; (ii) ensuring financial stability; and (iii) maintaining competitiveness.

Staff views: The broad fiscal targets are appropriate but 0.3 percent of GDP in additional fiscal measures per year in 2011-2013 will be needed to achieve them. Consolidation should rely more on durable measures. Pension reform is a critical step in the right direction but it is not enough to ensure fiscal sustainability. Banks should be further recapitalized and corporate governance strengthened, including through a larger role for the private sector. An exit strategy for the government's role as an investor in banks should be laid out. Wage growth should be restrained, labor markets should become more flexible, and products market reform is needed to attract FDI.

Authorities' views: The authorities agree with staff that fiscal consolidation including pension reform is key to ensure a sustainable recovery. The government considers that the recovery could be revived by stimulating credit expansion. The Bank of Slovenia emphasizes that banks' governance and capitalization should be enhanced, regardless of ownership. The authorities stressed also the importance of social consensus to implement reforms.

Mission team: Mr. Spilimbergo (Head), Ms. Mahieu, Mr. Simone (all EUR), and Mr. Blotevogel (MCD) visited Ljubljana March 9-21, 2011 and held discussions with the Mr. Križanič (Minister of Finance), Mr. Krajnec (Governor of the Bank of Slovenia) and other ministers, government officials and representatives of parliament, financial sector, labor, business, and media. Mr. Kavčič (Advisor to the Executive Director) attended also the meetings. Mr. Prader (Alternate Executive Director) attended the concluding meeting. 
Contents

Page

I. Context: From Sudden Stop to Difficult Deleveraging ................................................... 3

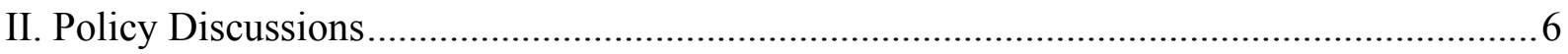

A. Outlook: Deleveraging and Lower Potential Growth are Contstraining the Recovery .. 6

B. Fiscal: The Challenges of Lasting Consolidation ............................... 8

C. The Financial Sector: State Involvement and Financial Stability ..................... 12

D. Structural Issues: Overdue Reforms to Boost Potential Output......................15

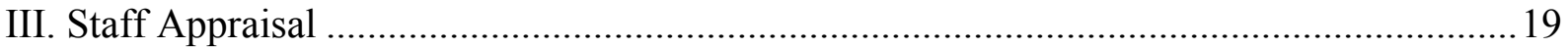

Boxes

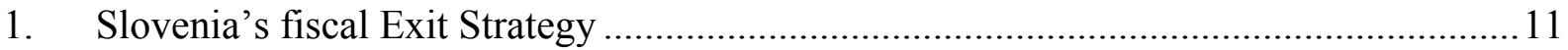

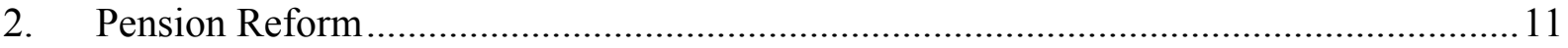

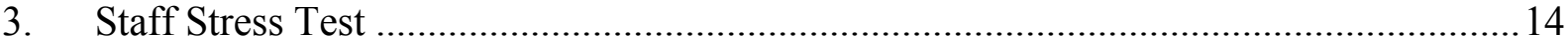

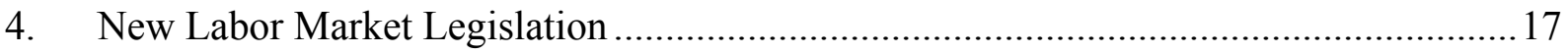

Figures

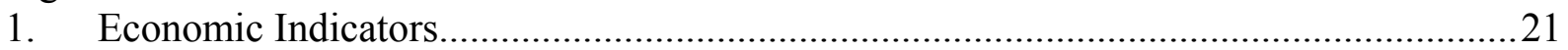

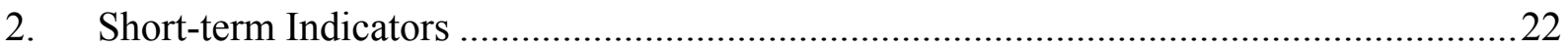

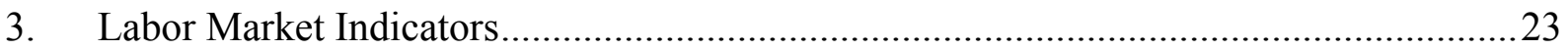

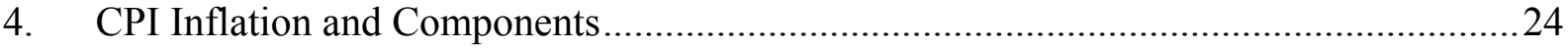

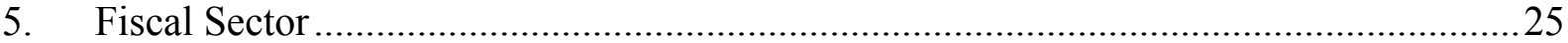

6. Public Debt Sustainability: Bound Tests .................................................................26

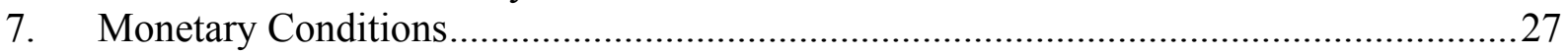

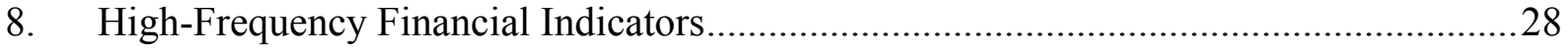

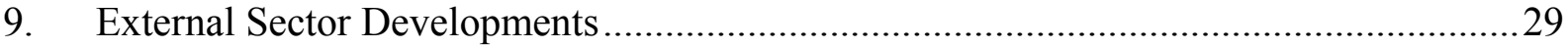

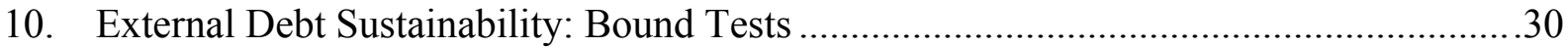

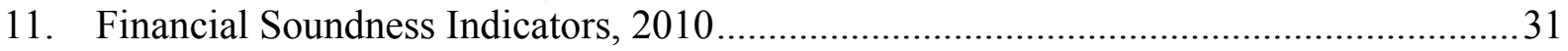

12. Bank Credit to Households and Nonfinancial Corporations in European Emerging

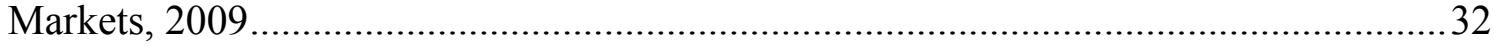

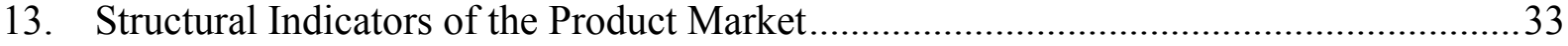

Tables

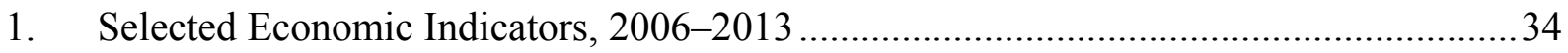

2. Consolidated General Government Operations (cash basis), 2006-2013 ..................... 35

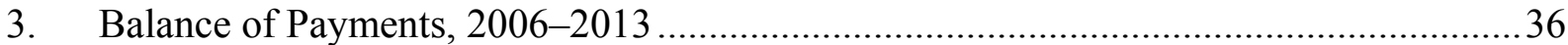

4. Slovenia Macroeconomic Framework, 2006-2015 ….................................................37

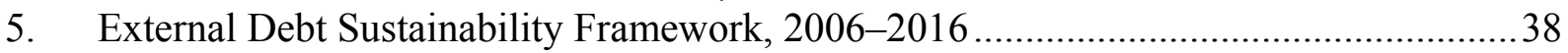

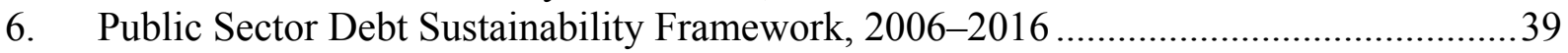

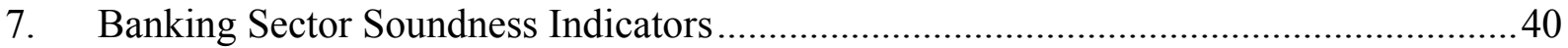

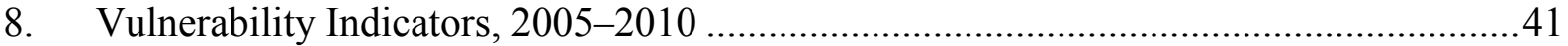




\section{ConteXt: From Sudden Stop to Difficult DeleVeraging}

1. Slovenia experienced one of the sharpest GDP declines in the euro area during the crisis. Real GDP declined over 10 percent from peak in Q3 2008 to trough in Q1 2010 owing to: a sharp decline in external demand affecting especially the manufacturing sector; a significant tightening in external credit conditions forcing banks to curtail domestic credit supply; and an abrupt end of a construction

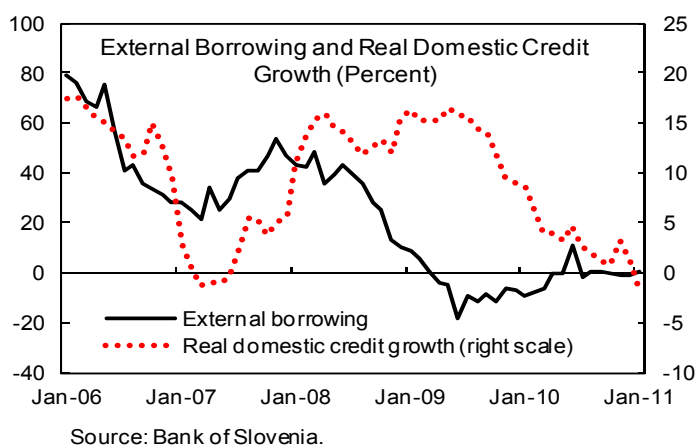
and housing price boom.
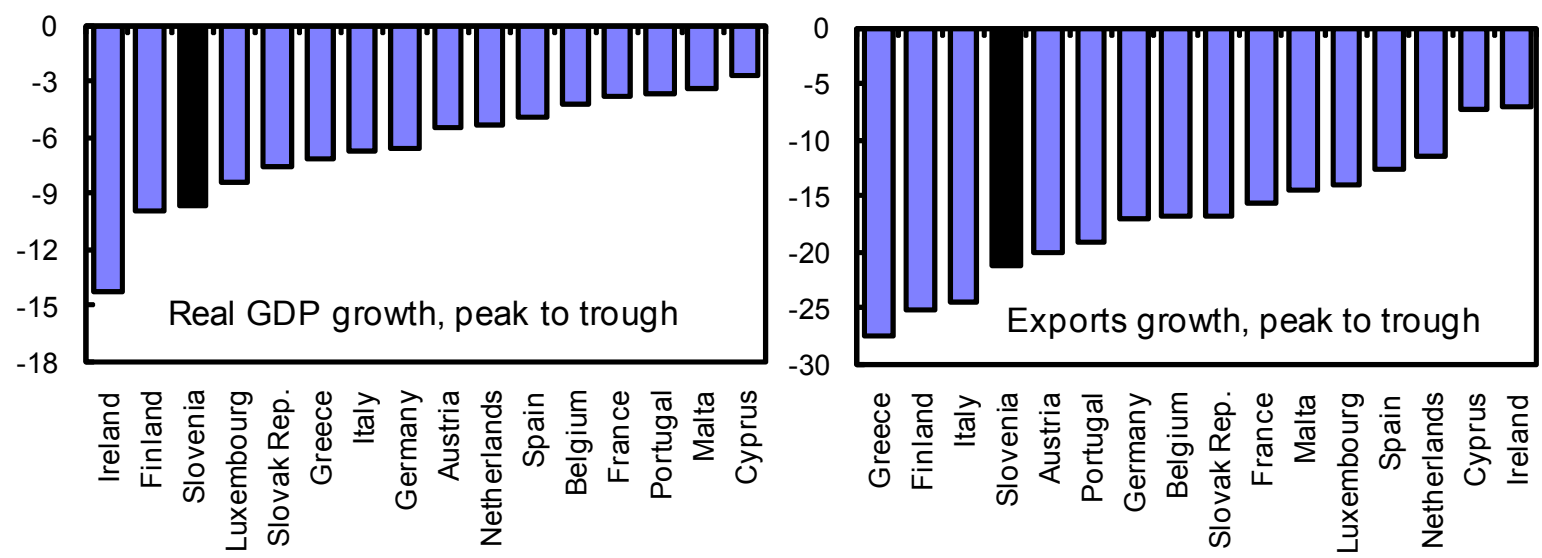

Source: Eurostat.

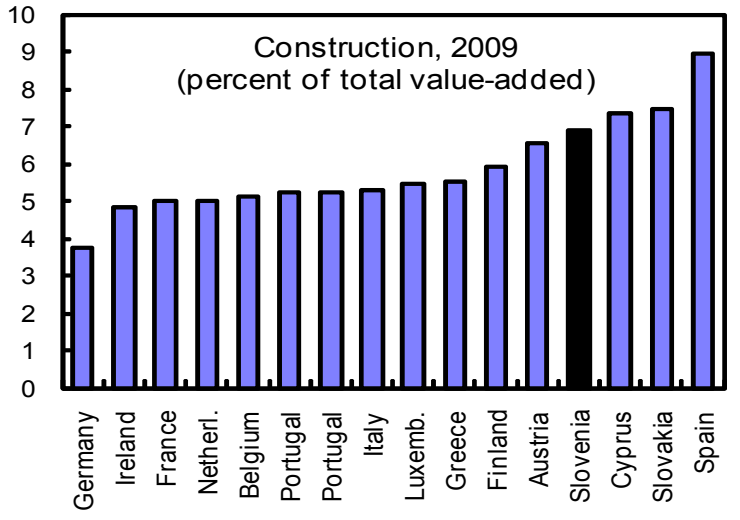

Source: Eurostat.

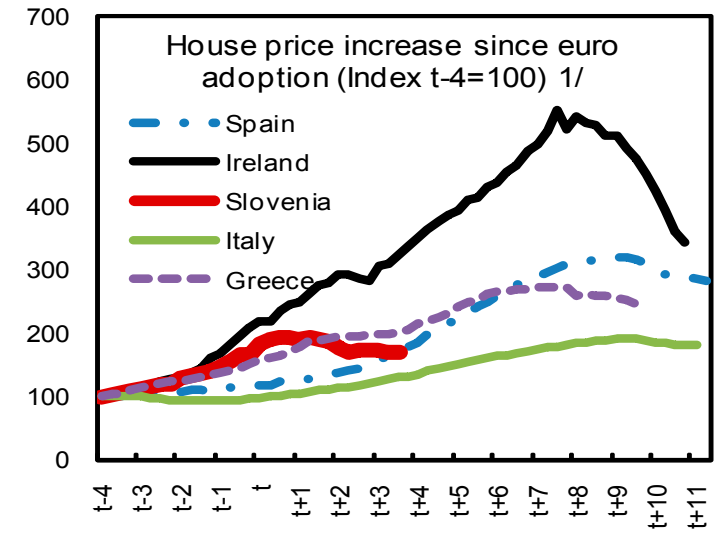

Source: IMF

$1 / \mathrm{t}$ is the euro adoption year in each country.

2. Economic growth has been slowly recovering on the back of external demand. Real GDP growth reached 1.2 percent in 2010. After declining in the first quarter of 2010, real GDP grew in the remaining three quarters, mainly driven by exports. However, domestic demand remains weak, with consumption only gaining 0.5 percent last year and investment 
flat. The highly leveraged construction sector is contracting while manufacturing is recovering. The average unemployment rate was 7.2 percent in 2010.
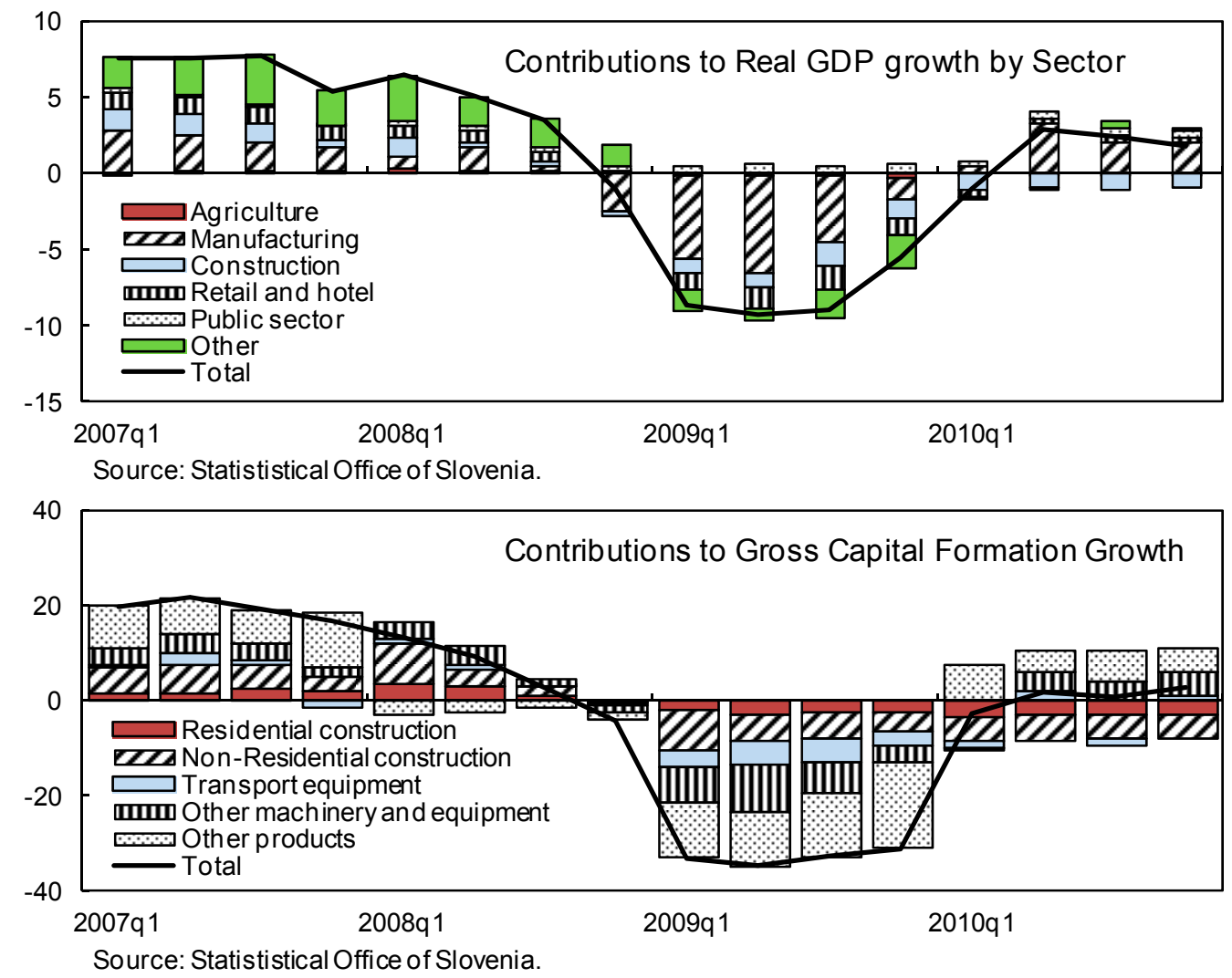

3. Weak domestic demand led to negative core inflation and greatly reduced the current account deficit. Average CPI inflation was 1.8 percent in 2010, mainly because of rising fuel and energy prices. The current account deficit shrank from 6.7 percentage points of GDP in 2008 to 1.2 in 2010, reflecting mainly the end of the construction boom.

\section{4. $\quad$ Fiscal policy turned countercyclical in} 2009. Automatic stabilizers were allowed to work and additional discretionary stimulus measures amounting to 1.8 percent of GDP in 2009, 0.2 in 2010, and 0.1 in 2011 were taken. Discretionary measures included subsidies to companies for shorter labor hours and R\&D, a corporate income tax rate reduction, and the elimination of the payroll tax. Most subsidies, except subsidies for temporarily

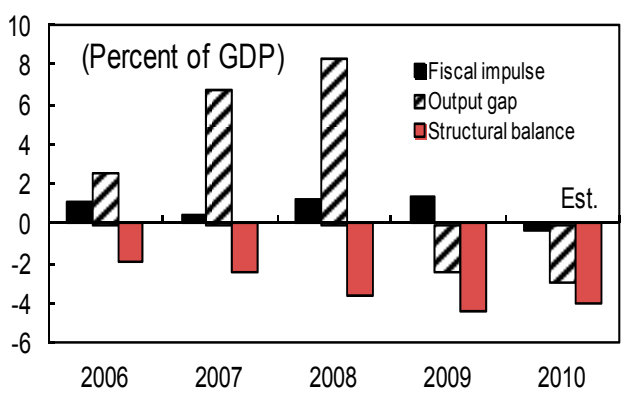
laid-off workers, were phased out by end-2010.

5. The general government deficit narrowed in 2010. After widening considerably during the crisis, the general government deficit declined to 5.2 percent in 2010. The main factors were one-off revenue gains, cuts in capital transfers, and containment of the wage 
bill. The structural balance also improved by 0.5 percent of GDP after reaching its lowest point in 2009 (-4.5 percent of GDP).

6. The crisis exposed vulnerabilities in the financial sector. The rapidly expanding credit growth financed with short-term external bank borrowing came to a sudden stop in 2008. During the crisis, the authorities supported bank liquidity by enhancing the deposit insurance scheme, placing government deposits with banks, and providing guarantees for banks' bond issuances. Banks also sought recourse to ECB funding. As a result, the funding profile of banks changed significantly.
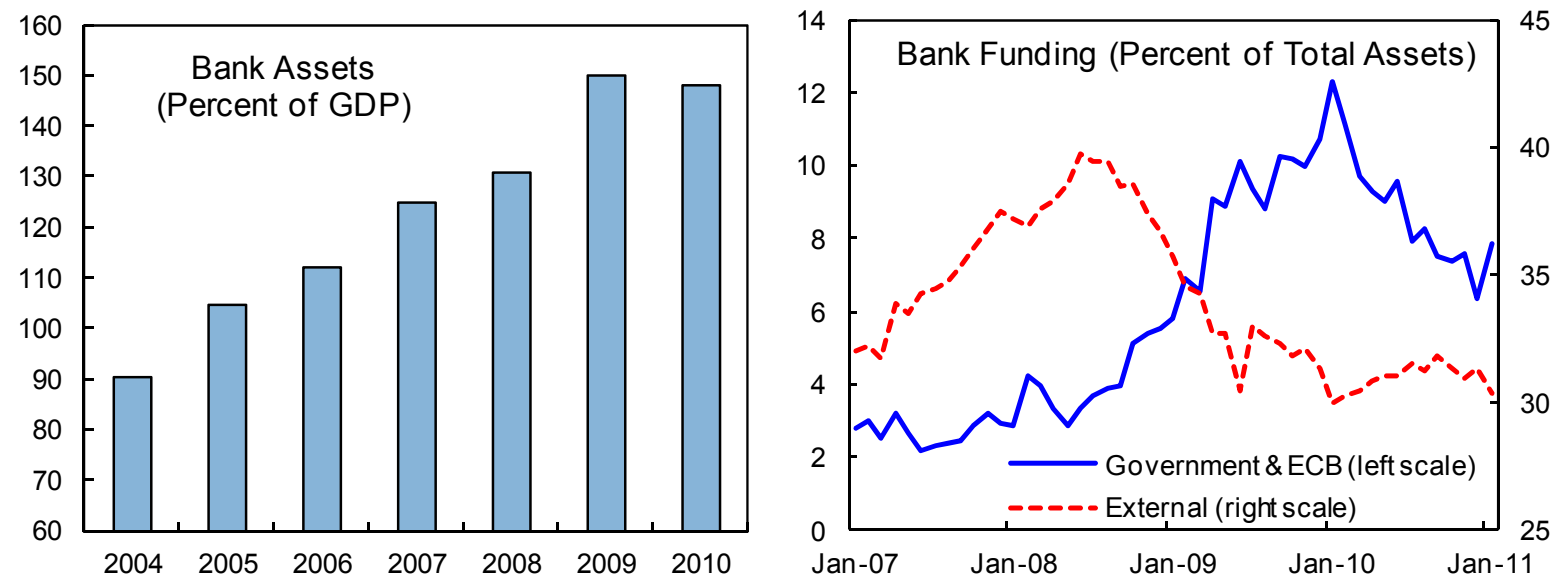

Sources: Bank of Slovenia; and European Central Bank.

7. Banks' profitability and asset quality deteriorated. Their aggregate profits turned negative in 2010 due to high loan losses. The share of non-performing loans reached 3.6 percent, up from 2.3 percent the year before. Loan concentration, particularly to highly-leveraged corporate borrowers, is high. Nova Ljubljanska Banka (NLB), Slovenia's biggest bank with a 28 percent market share by assets, barely passed the Council of European Banking Supervisors (CEBS) stress test in July 2010. Moody's downgraded

Slovenia's three largest banks in

September last year, while retaining

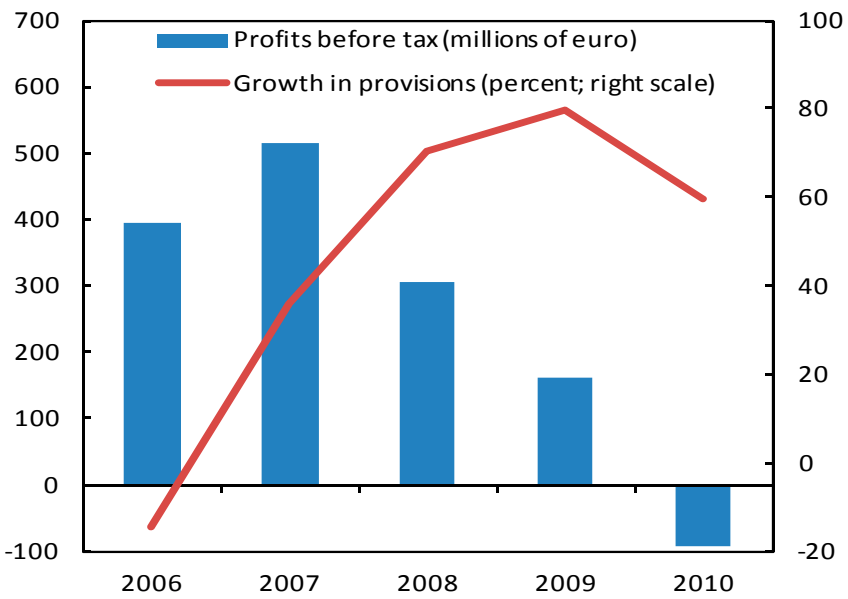
their negative outlooks.

8. The political context has not been favorable to the implementation of structural reforms. The political support for labor market and pension reforms is weak. Trade unions succeeded in holding a referendum on the recently approved revisions to pension and labor 
market legislations in spring (Boxes 2 and 4). Upcoming elections in 2012 are also likely to complicate reform implementation.

\section{Policy Discussions}

9. Policy discussions focused, for the short term, on the strength of the recovery in the context of deleveraging, bank vulnerabilities, and the fiscal exit strategy. For the medium term, the discussions were focused on pension reform and competitiveness.

\section{A. Outlook: Deleveraging and Lower Potential Growth Are Constraining the Recovery}

\section{Pervasive deleveraging will limit}

growth. Credit growth to the domestic privatesector fell to below 4 percent in 2010 from 33 in 2007, as banks tried to protect their capital positions and meet debt redemptions. The highly leveraged corporate sector has stopped borrowing, muting demand. Lending to households was the exception to the downward trend in 2010, mainly due to low initial debt levels and attempts by banks to shift risk away from construction companies.
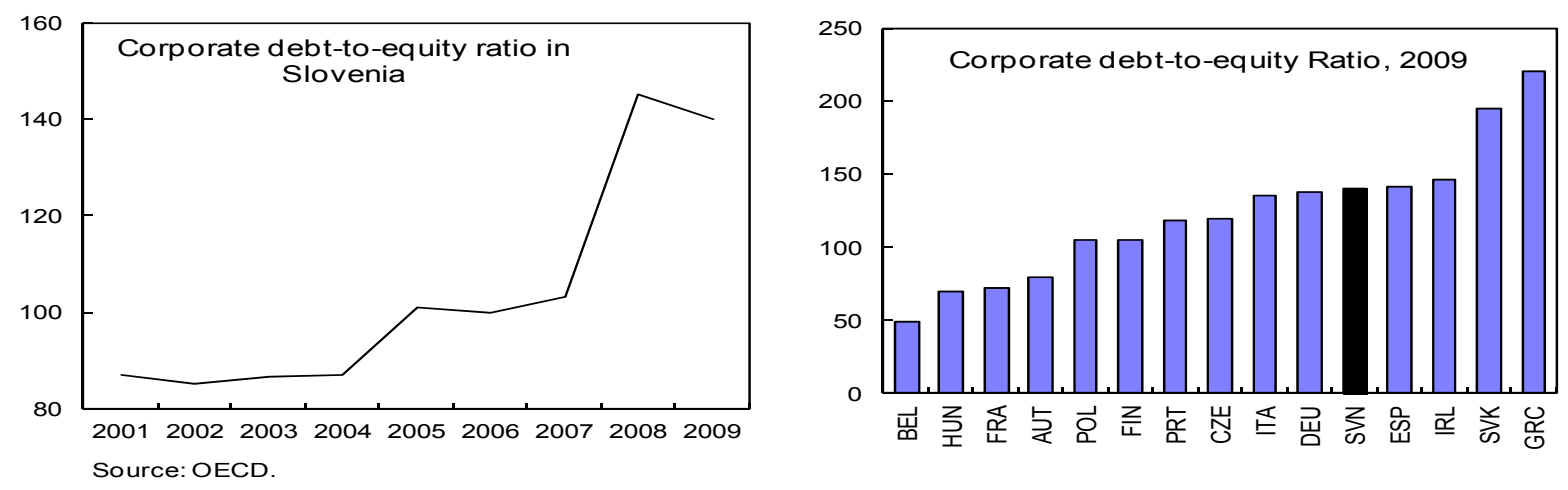

11. Supply factors are also constraining the recovery. Slovenia's GDP is already at 88 percent of the average euro area GDP, reducing the scope for further catching up. Moreover, post-crisis potential output growth estimates by the OECD, the European Commission, IMAD, and staff (see charts below) declined to a range of 1.3 to 2.5 percent from a pre-crisis range of 3 to 3.4, primarily on account of the lower gross capital formation. The output gap is projected to close gradually over the medium term. 


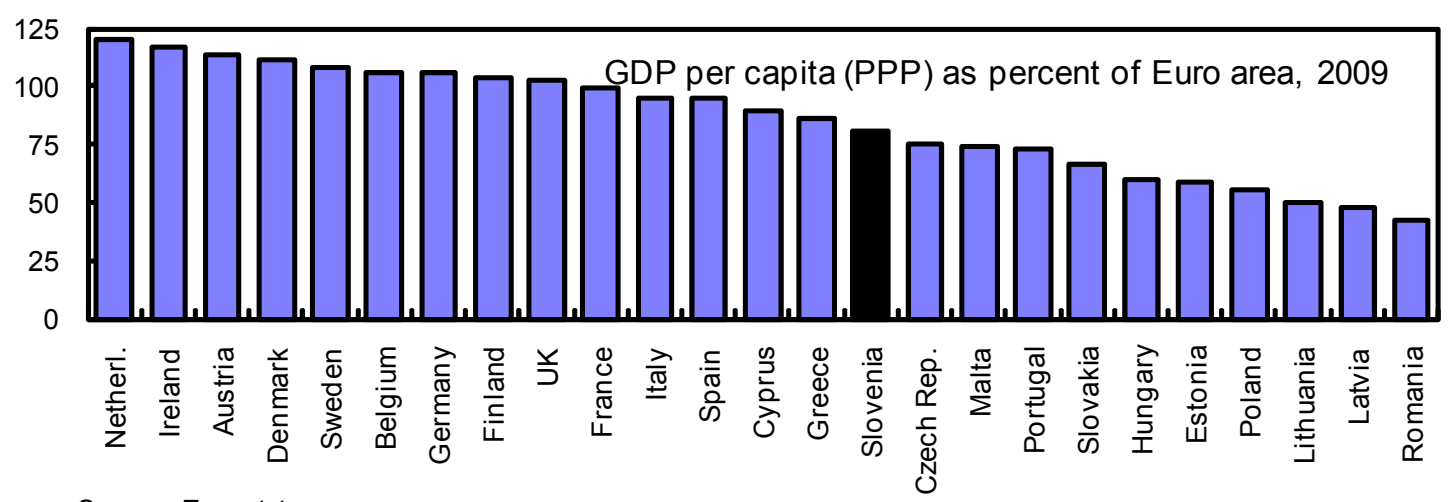

Source: Eurostat.
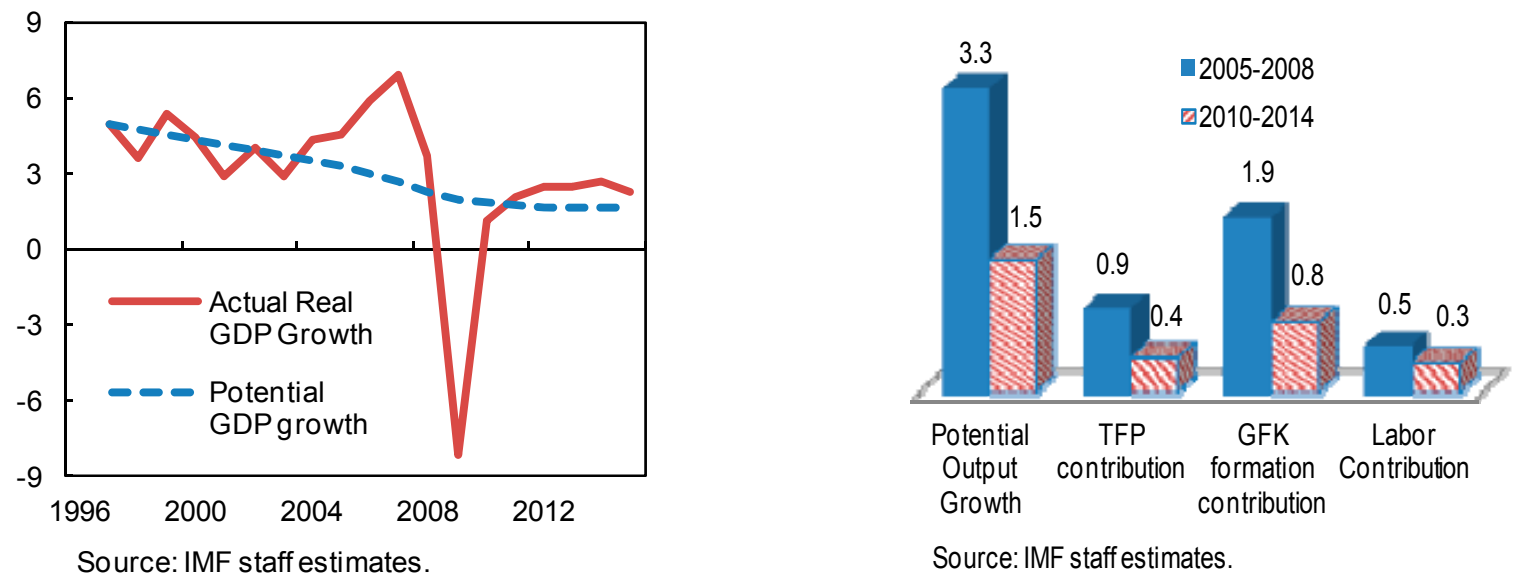

Source: IMF staff estimates.

12. GDP growth is projected at 2 percent in 2011 and 2.4 in 2012. The pick-up in growth reflects mainly a recovery in the manufacturing sector and inventory rebuilding. However, investment will likely be low due to deleveraging. High unemployment and fiscal retrenchment will weigh on consumption growth. Average inflation is projected to gradually pick up to 3.1 in 2012 on the back of high commodity prices. The current account deficit is expected to widen again as the economy recovers, but not as much as in pre-crisis times. The authorities broadly agreed with staff's forecasts.

\section{Spillovers from the European sovereign debt crisis have been contained so} far, but vulnerabilities remain. This resilience reflects Slovenia's moderate debt-to-GDP ratio, limited refinancing risk of public debt, and solid household balance sheets. However, the nearterm dependence of the recovery on external demand and significant contingent public liabilities from entitlement spending and banks

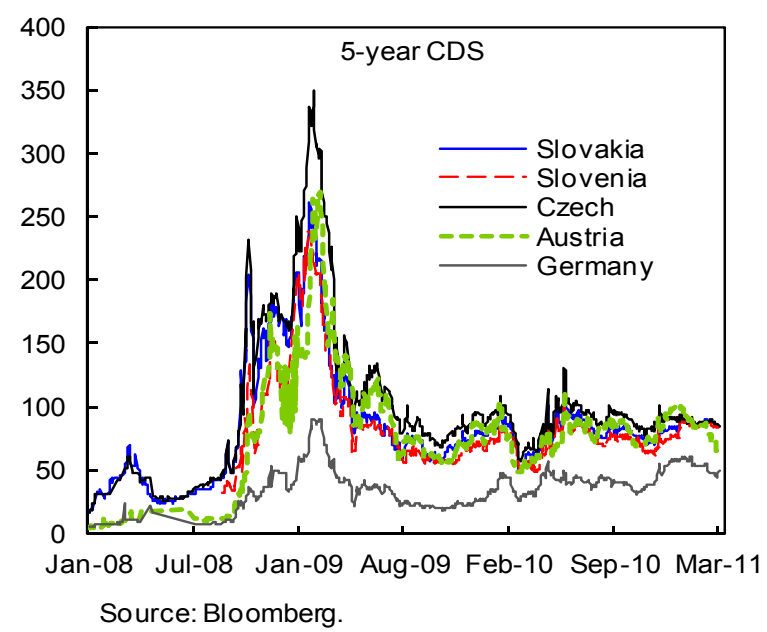


are ongoing risks. The postponement of pension and labor market reforms could also lead to further deterioration in competitiveness and potential output growth.

\section{B. Fiscal: The Challenges of Lasting Consolidation}

\section{The authorities' fiscal exit strategy envisions a gradual reduction of the general} government deficit to below 3 percent by 2013 in compliance with the EU's Excessive Deficit Procedure (EDP) (Box 1). Measures include freezes in basic wage, cuts in allowances, and reduction in public employment. Non-pension entitlement growth is expected to be contained by slowing down indexation. Structural fiscal reforms are also envisioned to support the consolidation.

15. Staff agreed with the contour of the authorities' exit strategy but pointed out that additional and durable measures are needed. While general government debt is likely to remain sustainable, fiscal consolidation is necessary in light of the uncertainty in financial markets and contingent liabilities. ${ }^{1}$ The government guaranteed $€ 2.2$ billion ( 6 percent of GDP) of banks' bonds during the crisis, which will mature next year, and may have to inject more capital into state banks, depending on market interest. However, staff's baseline scenario illustrates that measures envisaged so far fall short by 0.9 percent of GDP (in ESA95 terms) to reach the authorities' targets. The shortfall results from less optimistic assumptions on transfers and the wage bill. ${ }^{2}$ The authorities agreed with the need of a durable adjustment, underlining the role of pension and health care reforms. The pension reform recently approved by the parliament but subject to referendum is a step in the right direction but is insufficient in the long run (Box 2).

16. Staff and the authorities agreed on the composition and pace of adjustment. Consolidation should take place on the expenditure rather than the revenue side given an already high tax burden, especially on labor. To the extent that compliance with the EDP is restored by 2013 and borrowing constraints permitting, the focus should be on the quality of the adjustment measures.

\footnotetext{
${ }^{1}$ Debt sustainability analysis suggests that debt would remain sustainable and at or below 60 percent of GDP under a variety of scenarios with the exception of one with significantly lower growth. Standard \& Poor's put Slovenia on negative outlook on account of its seemingly weakened commitment to fiscal consolidation.

${ }^{2}$ The fiscal deficit could be higher by 0.7 percent of GDP in 2011 if Eurostat classifies the recently approved recapitalization of state banks as state aid for EDP compliance purposes. Eurostat's opinion would also determine the impact on the fiscal deficit of any additional recapitalization.
} 


\section{Staff proposed durable} expenditure measures. Suggestions included: preventing the policy adopted in 2008 to reduce wage disparities in the public sector from increasing the wage bill; rationalizing government employment; and reforms to strengthen the targeting of transfer programs and tighten eligibility. ${ }^{3}$ The authorities reiterated their commitment to consolidation. They agreed that additional measures over and above those announced would likely be needed to bring the general government deficit below 3 percent by 2013 .

\section{Staff indicated that the pension} reform goes in the right direction but is insufficient to ensure long-term fiscal sustainability. Slovenia is projected to have one of the largest pension expenditures in the EU by 2050 if no reform is implemented. This is due to a combination of rapid ageing, low effective retirement ages, and wage indexation of benefits. The pension reform would contain the increase

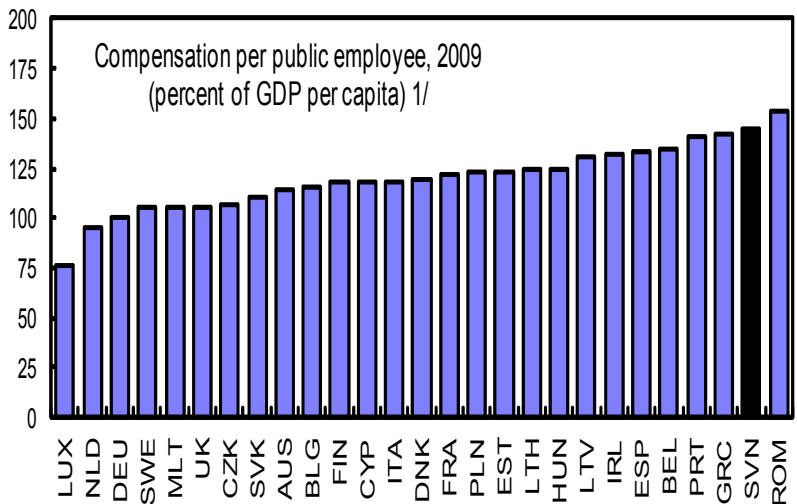

Sources: World Economic Outlook; Eurostat; and Statistical Office of the European Communities. $1 /$ Latest data available for Portugal and Romania, 2007 and 2008 respectively. to about 6 percent of GDP by 2060, but would still imply unsustainable transfers from the state budget. Staff recommended further reducing the replacement rate and increasing more rapidly the effective retirement age to 65 years by: (i) increasing the penalty for early retirement to 6-7 percent per year; (ii) moving indexation gradually towards price indexation; and (iii) automatically adjusting retirement age to life expectancy at retirement once the pensionable age reaches 65 for women and men. Finally, the private pillar should be expanded to compensate for the public benefit cuts while ensuring the portability of the

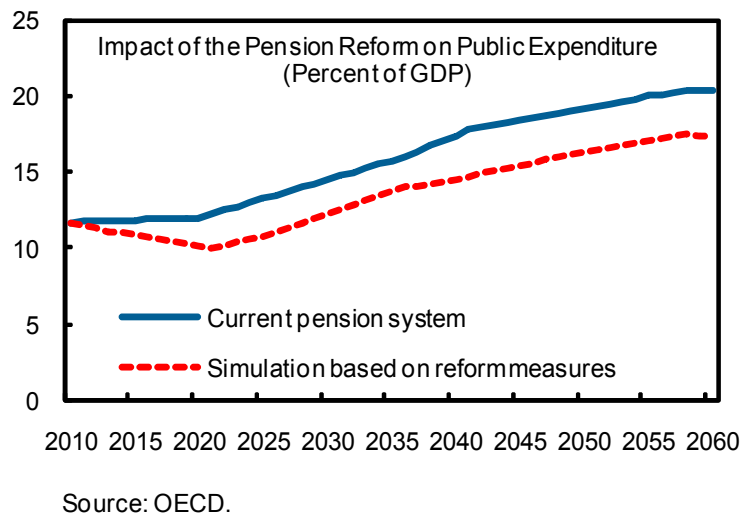

${ }^{3}$ Reducing government employment by 1 percent each year for two years as proposed in the 2009 stability program update could save 0.2 and 0.4 percent of GDP in 2011 and 2012 respectively. 
benefits. The authorities agreed with staff that additional measures beyond the current pension reform will be needed to ensure long-term sustainability and noted that the defined contribution private pension pillar is also being reformed (Box 2).

19. Public debt management has been broadly adequate. Long-term syndicated loans issued at fixed rates were used to pre-finance the deficit while limited quantities of short-term treasury bills were issued to manage treasury liquidity. Staff recommended that the authorities continue to pre-finance to hedge against refinancing risk.
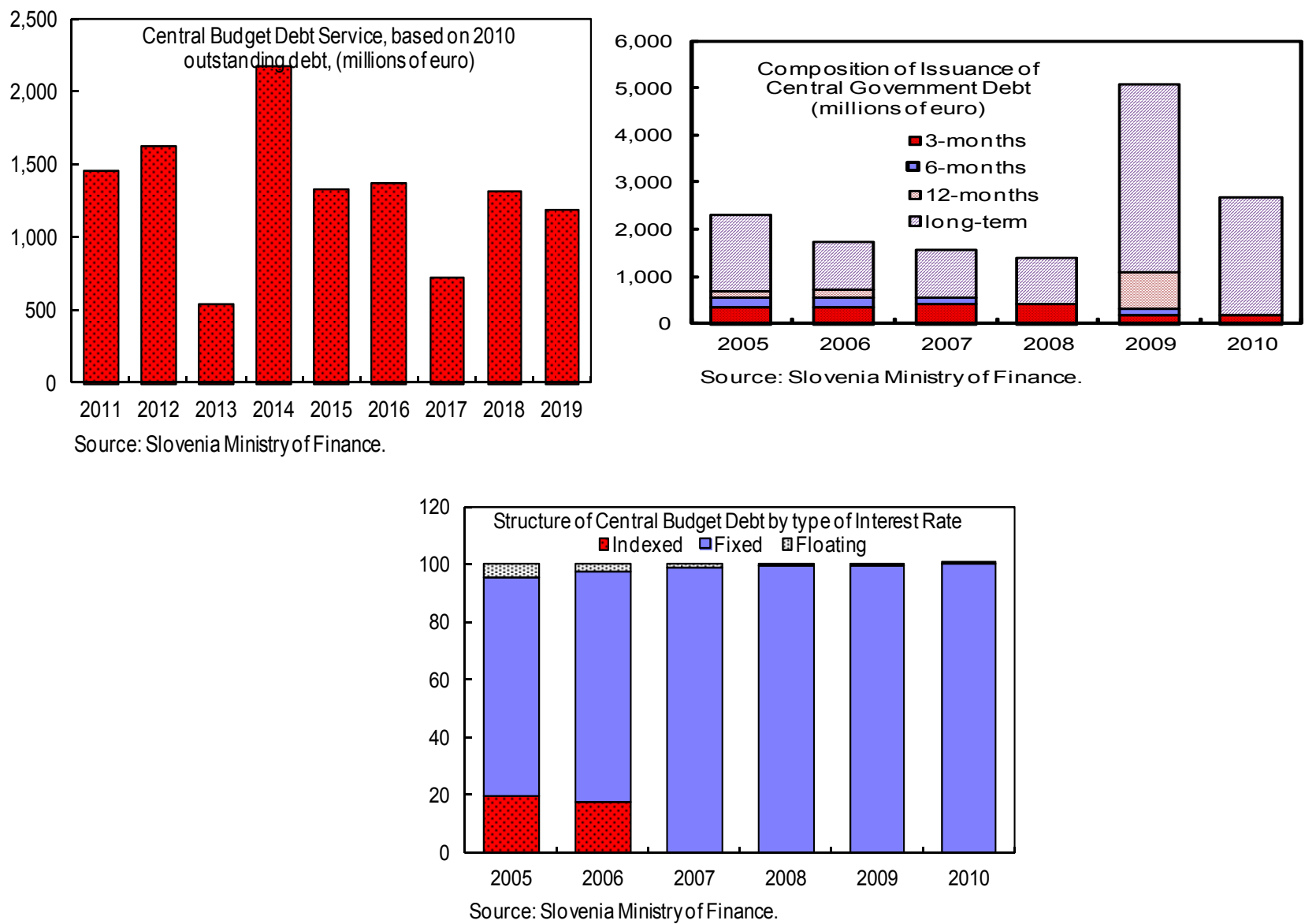


\section{Box 1. Slovenia's Fiscal Exit Strategy}

The authorities' exit strategy seeks to achieve near-term fiscal consolidation and address sustainability challenges arising from age-related spending. In addition to the withdrawal of the crisis-related discretionary measures, the plan includes:

- Expenditure-based fiscal consolidation. Key elements are rationalizing the wage bill, social benefits, and goods and services. Wage bill growth would be contained by the abrogation of regular performance bonuses until 2011, the postponement of the implementation of the wage disparity policy in the public sector, the non-indexation of wages to inflation in 2011 and 2012, and the reduction of public employment by 1 percent in 2011 and 2012. The growth of social benefits would be curtailed by using a less generous indexation. Goods and services would be rationalized by introducing a unified system of public procurement.

- $\quad$ Fiscal structural reforms. These include pension, health care and financial management reforms. Health care reform aims at increasing the use of generic drugs, tightening the eligibility for sick leave benefits, changing the ratio of health services and medicine covered by mandatory and voluntary health insurance, and widening the income base for the collection of health contributions. In the public financial management area, reforms include performance budgeting and changes to the Public Finance Law. The changes will introduce in the legislation a medium-term framework (MTF), institute a formula for computing the expenditure ceilings based on MTF ("fiscal rule"), set a debt ceiling of 45 percent of GDP, and 13 percent of GDP on government guarantees, and define the responsibilities and accountability structure for the recently created fiscal council.

\section{Box 2. Pension Reform}

The government approved a pension reform in November 2010 which will be challenged in a referendum in late spring. The main elements are the following:

- An increase in the full and minimum retirement ages. The statutory retirement age will be lifted to 65 and the minimum retirement age will be 60 . The gap between the retirement ages of men and women progressively disappears. The retirement age for workers with longer careers also increases to 60 for men and 58 for women.

- A gradual extension of the period for calculating the pension base from the 18 best consecutive years to 27 years. The extension will decrease the pension rating base by 12.1 percent for men and 10.5 percent for women. However, the replacement rate will be capped at 60 percent.

- A change in the indexation of pension benefits. Instead of only indexing to nominal wage growth, the new approach also links pension benefits to prices (40 percent weight until 2015; 30 percent thereafter).

- Changes in the incentive system. Individuals who are eligible for a pension, but continue to work full time, will be able to claim 20 percent of their pension entitlement. The permanent penalty for early retirement will be increased to 0.3 percent per month before the age of 65 .

- Additional incentives to work past the pension eligibility age. Partial retirement will be extended, allowing for greater flexibility in combining work and pension benefits.

- Financial incentives for employers to employ older workers. Employers will pay 30 percent lower social security contributions for workers above the age of 60 . Hiring workers with long careers over the transitional period until 2017 results in a 50 percent reduction in social security contributions for employers.

- Introduction of portfolio choices for workers opting to participate in the voluntary occupation scheme and a revised minimum return guarantee. 


\section{The Financial Sector: State Involvement and Financial Stability}

20. Banks are coping with declining profitability. The deterioration in banks' asset

quality, evidenced by rising arrears, provisions, and non-performing loans, will moderate only slowly under staff's baseline scenario. Provisions are expected to continue to act as a drag on banks' profits. This limits the scope for retained earnings to boost capital in the near term.

21. The highly indebted corporate sector is driving loan losses. The debt-to-equity ratio in the non-financial corporate sector jumped to 140 percent in 2009, up from 90 percent in 2000. Leverage is also high compared to other euro area members. Borrowing by construction, real estate and leveraged holding companies grew particularly fast, with these sectors accounting for a quarter of all corporate lending at the end of 2010. Given the unfavorable environment for these sectors, banks are likely to realize further losses on the associated exposures. The authorities are considering a tax on banks' assets to incentivize lending to the corporate sector. While appreciating the need to ensure adequate credit supply for credit-worthy companies, staff noted that a tax penalizing banks for scaling back exposures to risky borrowers would distort banks' risk management. But staff saw some merit in having a systemic approach to the management and selling of stakes in non-financial companies that banks seized as collateral following bankruptcies. This solution should aim at making banks' portfolio more transparent and accelerating the restructuring of companies if necessary. However, the approach chosen should have no fiscal implications.

\section{The recent pickup in mortgage lending warrants careful monitoring. While} households remain less indebted than in other EU countries, their debt-to-GDP and debt-to-income ratios have deteriorated relatively quickly since the EU accession in 2004. The near-term dangers of imbalances in the housing market are limited by relatively stringent limits on loan-to-value and debt servicing-to-income ratios. But given the risks posed by large stocks of unsold apartments and rising interest rates, with most loans contracted at variable interest rates, the authorities agreed with staff that lending to households should be monitored carefully. The Bank of Slovenia (BoS) indicated their willingness to tighten prudential regulation further if necessary.

23. Banks' funding is set to become more expensive. Acute liquidity pressures are absent, but at 146 percent, banks' domestic loan-to-deposit ratio is high, indicating significant refinancing needs of foreign liabilities. With borrowings from the ECB and the government recently scaled back and foreign funding restricted, banks shrunk their total assets in 2010. Given the limited scale of the local deposit market and continued strains in international wholesale markets, funding costs are bound to increase when banks' lending activities will resume across the board, with negative effects for net interest margins. 


\section{Under Basel III, banks will have} to strengthen their capital ratios.

Slovenian banks are thinly capitalized. The introduction of Basel III will exacerbate this problem, though less than in other countries thanks to more limited use of hybrid capital and tighter supervisory requirements. Preliminary estimates by the BoS found that Tier 1 capital ratios would fall by at least 0.7 percentage points on average, assuming that Basel III rules take effect immediately. Staff's stress test also indicates a need to raise additional capital, which would allow banks to maintain prudent buffers even in a severe adverse scenario. The BoS broadly agreed with the results, but emphasized that stress tests are sensitive to the severity of the assumptions used (Box 3 ).

25. Strengthening capital buffers is key for financial stability. Even in the absence of shocks, additional capital is desirable to bring capital adequacy to more prudent levels, bolster confidence, and create new lending capacity. The two largest banks are currently raising capital from the government and markets but the amounts are probably insufficient to meet current market standards of capitalization. Staff encouraged the authorities to pave the way for a greater role of private investors. This can be achieved by laying out an exit strategy for the government as investor in banks, strengthening governance, disposing non-strategic assets, and removing doubts about asset quality through strict capital and provisioning requirements. Raising additional capital would ease the need to shrink domestic lending in a difficult time, moderating the fallout from large-scale bankruptcies in the construction sector. The authorities agreed with staff about the importance of adequate capitalization. They have started to examine options for further recapitalization, including through partial divestment. 


\section{Box 3. Staff Stress Test}

Staff conducted a stress test to assess the resilience of Slovenia's two largest banks in an adverse scenario. The methodology is based on the background analysis carried out for the April 2011 Global Financial Stability Report, with some inputs taken from the EU stress tests organized by CEBS in July 2010. The adverse scenario covers the financial years 2011 and 2012 and features three shocks: (i) $a$ loan loss shock; (ii) a sovereign shock reducing the value of banks' sovereign bond holdings; and (iii) $a$ Slovenia-specific funding shock squeezing net interest margins. Staff's test is on balance more severe than CEBS' exercise. To illustrate, staff's two standard deviation shock to loan loss rates gives annual provisions of 2.9 percent of gross loans for NLB, compared to 2 percent in the CEBS test from last year. The staff test's main assumptions are that balance sheets remain constant and that net non-interest income equals the average of 2008/09. The results reflect already announced recapitalizations at the end of March and are summarized in the following table:

\begin{tabular}{lr}
\hline \multicolumn{2}{c}{$\begin{array}{c}\text { Capital needs in addition to already announced } \\
\text { recapitalizations to meet Tier 1 targets } \\
\text { (in } € \text { million) }\end{array}$} \\
\hline Net income after shocks & -490 \\
in percent of current risk-weighted assets & $2.3 \%$ \\
Capital needed for Tier 1 to reach 6\% & 50 \\
in percent of current Tier 1 & $4 \%$ \\
in percent of 2010 GDP & $0.1 \%$ \\
Capital needed for Tier 1 to reach 8\% & 420 \\
in percent of current Tier 1 & $30 \%$ \\
in percent of 2010 GDP & $1.2 \%$ \\
Capital needed for Tier 1 to reach 10\% & 840 \\
in percent of current Tier 1 & $61 \%$ \\
in percent of 2010 GDP & $2.3 \%$ \\
\hline
\end{tabular}

These results need to be interpreted with caution. The exercise is stylized, and does not take banks' possible mitigation measures into account. The results are particularly sensitive to changes in the loan loss shock. That said, the test shows that the banks could benefit from raising additional capital to bolster confidence in their ability to withstand harsh, but low-probability, events. 


\section{Structural Issues: Overdue Reforms to Boost Potential Output}

26. While the real effective exchange rate is broadly in line with fundamentals, the authorities agreed that maintaining competitiveness will be crucial. The crisis induced a sharp correction of current account imbalances, but indicators of price and cost competitiveness further deteriorated since then (see charts). Slovenia's world market share in labor-intensive products has declined, unlike many of its neighbors. Given the large share of labor-intensive products in

Equilibrium exchange rate estimates using CGER methodology (percent) $1 /$

\begin{tabular}{lc}
\hline Macroeconomic balance & 1.5 \\
Reduced-form equilibrium exchange rate 2/ & -12 \\
External sustainability & 1.0 \\
\hline 1/ Positive numbers indicate that REER is above equilibrium. \\
Estimations based on fall WEO data except updated Slovenian CA projection. \\
2/ The sharp appreciation of the REER forecasted by the model is entirely \\
due to a strong trend in relative productivity of the tradable sector
\end{tabular}

Slovenian exports, worsened cost competitiveness, if not addressed, will constrain export growth.

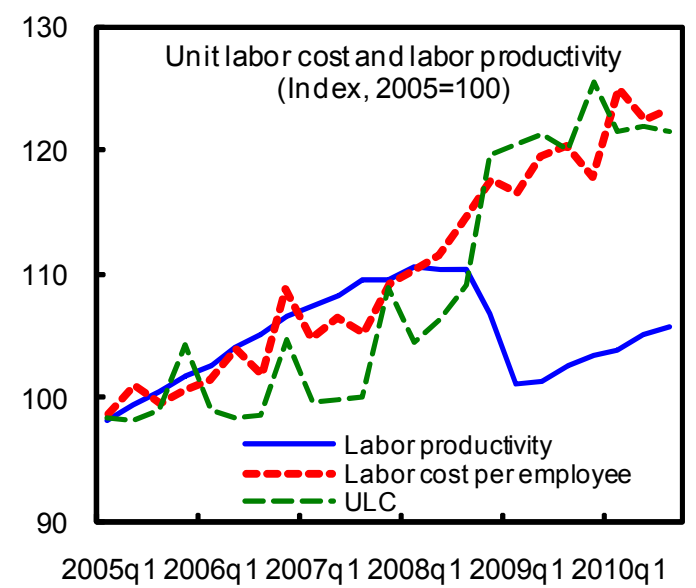

27. The crisis threatens to have a durable dampening impact on employment.

Subsidies for full-time working hours and temporary laid-off workers mitigated the increase in unemployment, although the return of foreign workers to their home countries may also have helped. Unemployment compares favorably to other euro area countries. However, the many job losses in the construction sector are probably permanent. 

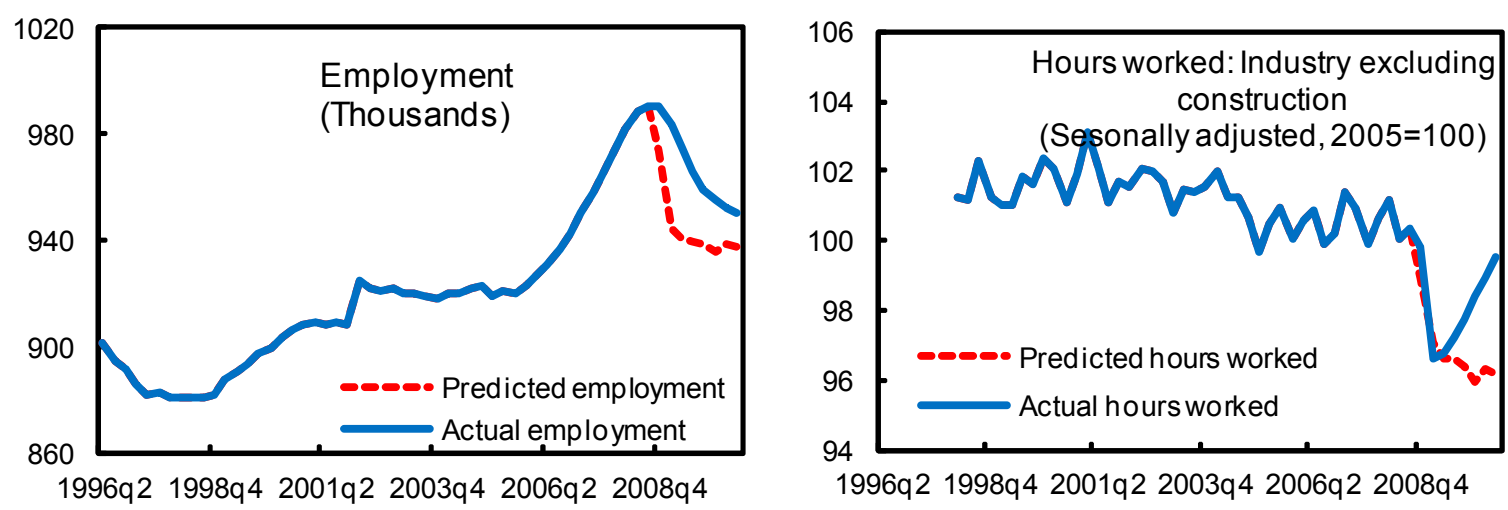

Sources: Statistical Office of Slovenia; and IMF staff calculations.

The predicted paths are based on a reg ression of total employment (left panel) or hours worked in industry exclud ing construction (right panel) on contemporaneous real GDP g rowth (left panel) or on valued-added excluding construction (right panel) during 2000q 1-2008-q3. The estimated coefficients are used to predict the employment/hours worked path from $2008 \mathrm{q} 4$ onwards.

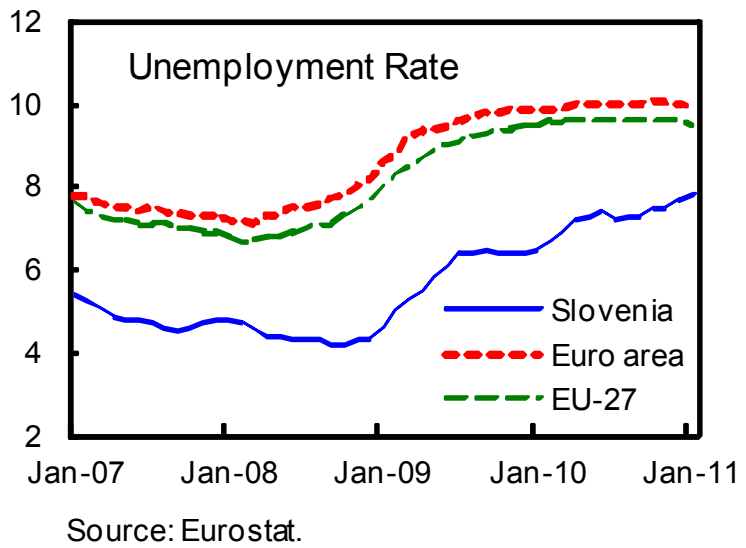

28. Labor market flexibility should therefore be increased. The Mini-Jobs Act regulating student work (Box 4) and the pension reform could contribute to increasing employment. In addition, staff advocated reducing regular workers' employment protection, which remains among the highest in OECD countries. In particular, staff recommended rapid enactment of the envisaged reduction in notice periods and severance payments as this would help avoid increasing labor market dualism and foster FDI inflows. The authorities share staff's assessment but pointed to the need to reach a social consensus. 


\section{Box 4: New Labor Market Legislation}

The Slovenian labor market suffers from low participation of older workers; low employment rate of the young; and a dual labor market. Permanent contracts impose a high cost on firms due to the obligation of paying high social security contributions, long notice periods for dismissal, high severance payment, and restrictions on dismissals. The student job status did not carry many of these restrictions, and was therefore misused as a substitute for standard employment.
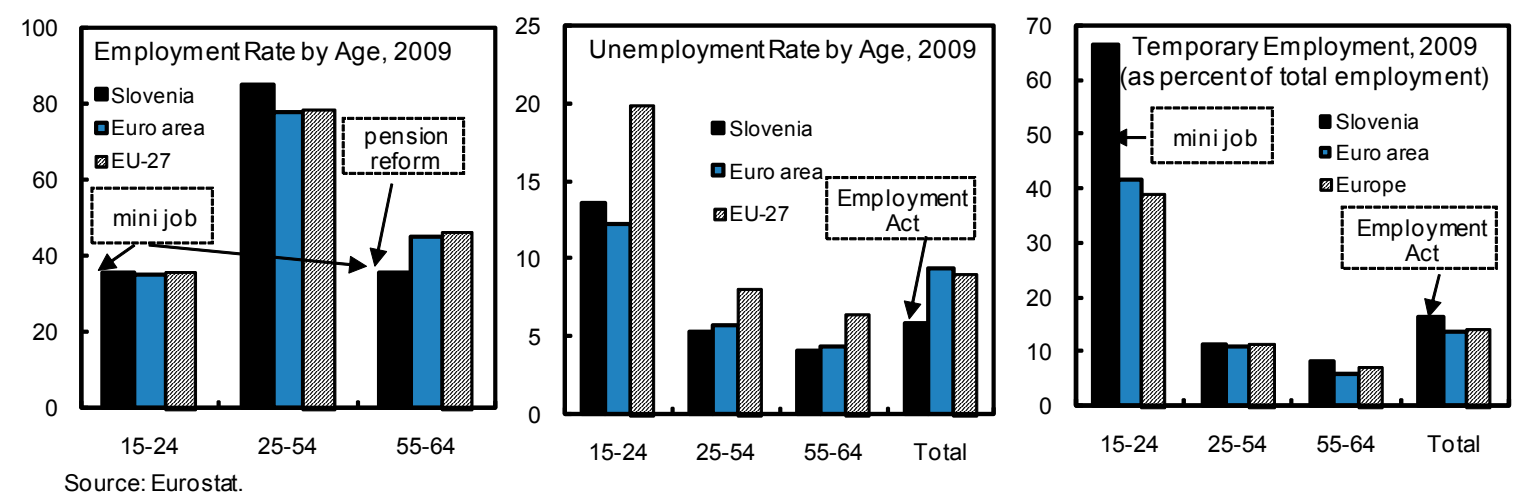

The government has adopted two new legislative measures mainly aimed at reducing the segmentation of the labor market, while increasing social protection of the young:

The Act on Mini Jobs improves the regulation of student work by restricting its possible use and increasing social security and pension contributions. The Act also expands the pool of potential users to pensioners and unemployed. The Act has been adopted in the Parliament but could be repealed in a referendum.

The new draft Labor Market Regulation Act primarily aims at increasing young workers' social protection by extending unemployment benefits to workers employed for nine months during the previous 24 months. The Act also increases unemployment benefits to an 80 percent replacement rate during the first three months.

In order to increase labor market flexibility, changes to the Employment Act are envisaged to shorten the notice periods for dismissals of workers and reduce the severance payments.

\section{Staff indicated that the increase in minimum wage implemented in $\mathbf{2 0 1 0}$ will have adverse effects on competitiveness and employment. At about 50 percent of the} average wage, the minimum wage was already higher than in most EU countries. The 23 percent increase prevented wages to fully respond to the downturn. It hurt employment in labor intensive sectors and put upward pressure on the general wage level, exacerbating already high unit labor cost compared to regional peers. The increase is also likely to reduce incentives for workers to increase their human capital by compressing the wage differential between unskilled and specialized low-skilled workers. The authorities stressed that the increase responded to a request of social partners and has so far not had significant impact on employment, although they recognized that it resulted in wage compression and could have negative effects on competitiveness. Staff suggested that eliminating the mandatory wage 
supplement for years of service could foster employment, particularly of older workers. Consideration should be also given to avoid any further indexation of the minimum wage.
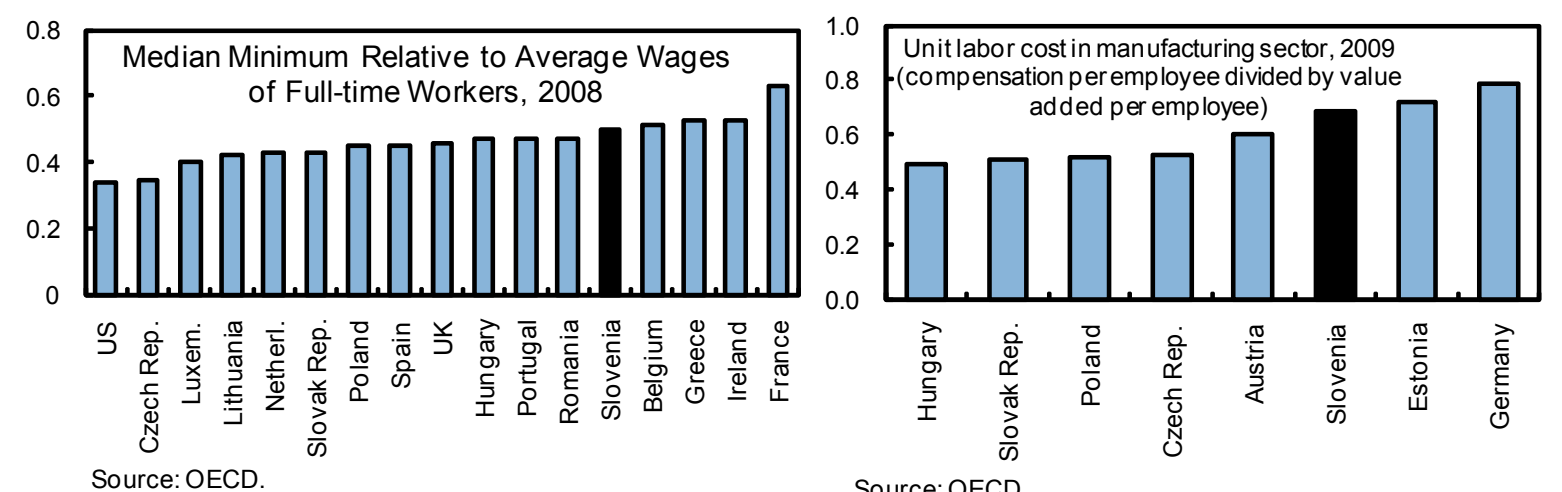

30. Improvement in the business environment would enhance FDI attractiveness

and boost productivity. Slovenia ranks relatively low in indices of competitiveness and ease of doing business. FDI inflows have therefore been weak, notably in manufacturing and network industries. In the last two years, the authorities have adopted several measures to improve business environment, including the creation of one-stop shops for establishing new companies. Further initiatives are currently contemplated to reduce administrative burden, facilitate procedures to obtain construction permits, accelerate bankruptcy procedures, and introduce a cap on social security contributions, compensating any potential revenue loss. Staff supported these initiatives as they could help enhance Slovenia's attractiveness as a destination for FDI.
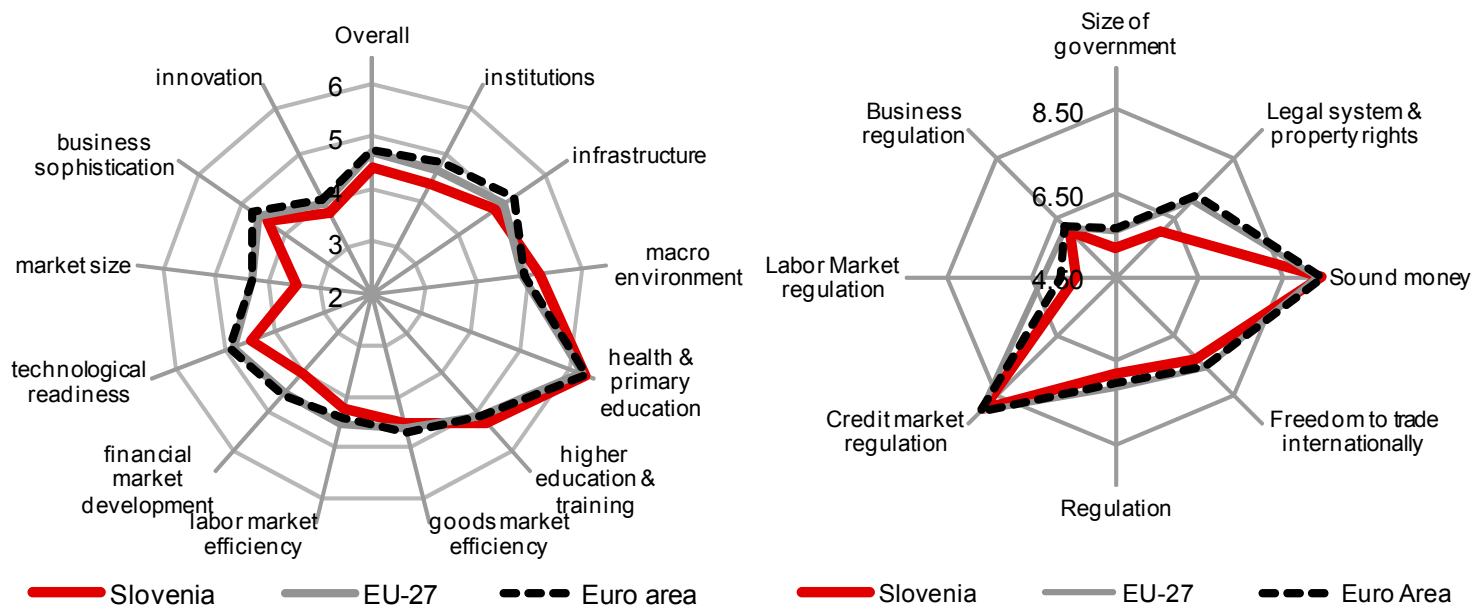

Sources: Global competitiveness Report 2010-2011, World Economic Forum; and Economic Freedom of the World: 2010 Report, Fraser Institute. A higher value indicates a better perfo mance. 


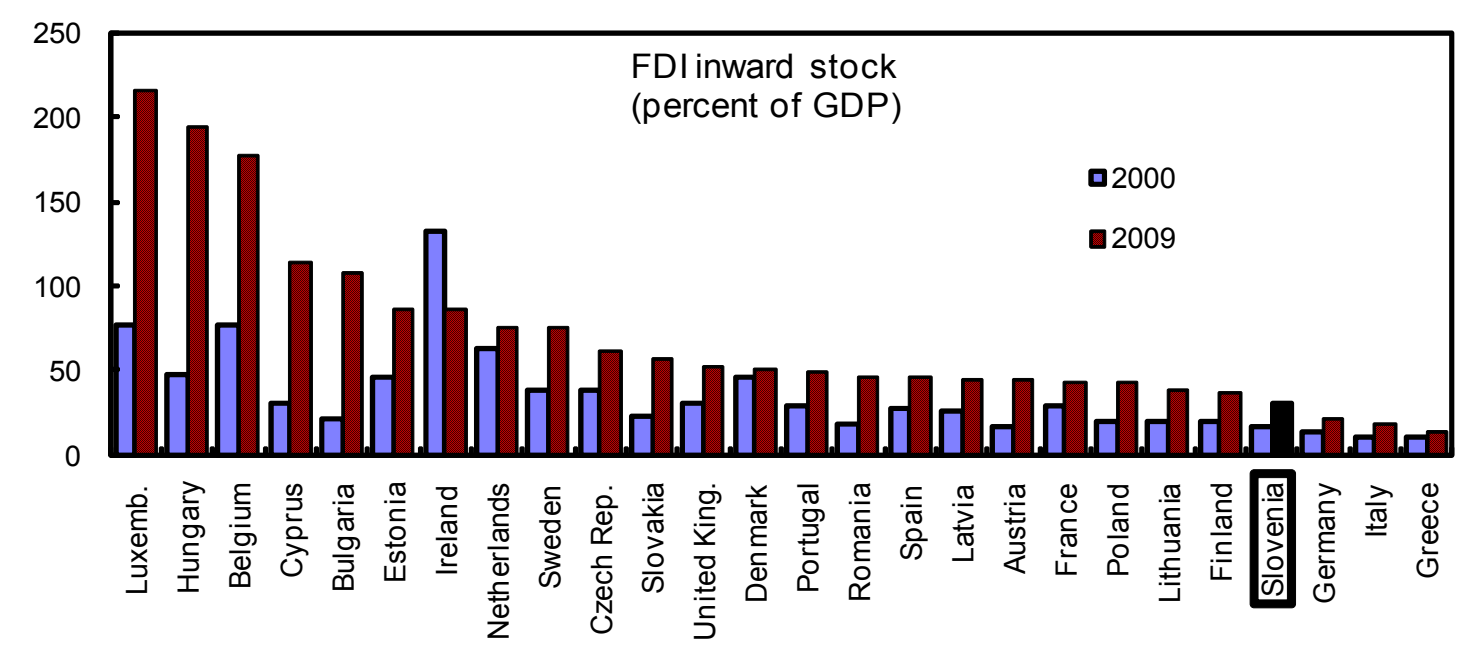

So urce: UNCTAD, FDI/TNC database.

\section{Staff APPRAisal}

31. The global crisis exacerbated the Slovenian economy's previous imbalances in the fiscal, financial, and real sectors. Easy external financing conditions and expansionary fiscal policy before the crisis led to a credit boom, rising debt in the corporate sector, and increasing wages. The global financial crisis and the sharp fall in external demand brought the domestic boom to an abrupt end. The legacy of the boom-bust cycle is an over-indebted corporate sector and weaker banks. This cycle also contributed to current large fiscal deficits, higher unemployment, and deteriorated competitiveness. Also, high pre-crisis growth led to unfounded expectations that Slovenia could grow out of its structural problems, leading to postponement of long-overdue reforms. Policy makers and social partners should recognize that structural reforms are needed for potential output growth to return to pre-crisis levels.

\section{Fiscal consolidation targets are appropriate but the measures announced so far} are insufficient to achieve these goals. In light of the uncertainty in financial markets and contingent liabilities, the planned consolidation is necessary. The authorities are committed to the consolidation path. However, additional measures over and above those announced so far are needed to sustainably bring the general government deficit below 3 percent by 2013 . Measures are mostly temporary and largely rely on extending policies introduced in 2011.

33. Durable consolidation measures should be specified and implemented. The policy of removing disparities in public sector wages should not increase the general government wage bill, and social programs should be better targeted and their eligibility criteria tightened. The government should also reduce public sector employment by 1 percent per year in 2011 and 2012 as planned in the stability program. The rise in the minimum wage that was already implemented last year may put pressure on the public wage bill when the temporary containment measures are lifted; lasting consolidation measures should be introduced to offset this effect if it materializes. 
34. The pension reform approved by the parliament is a step in the right direction but is insufficient in the long run. Slovenia is projected to have one of the largest pension expenditures in the EU by 2050. By increasing retirement age and lowering the replacement rate, the pension reform will improve fiscal sustainability. However, projections suggest that transfers from the state budget to the pension fund would remain very large even after the pension reform. Additional measures will need to be implemented going forward to ensure sustainability, including: a more rapid increase in the effective retirement age to 65 years of age for both men and women; moving indexation gradually towards full price indexation; and automatically indexing the retirement age to life expectancy at retirement once an effective retirement age of 65 has been attained. In case of rejection of the pension reform in the referendum, temporary measures such as a freeze in pensions until a new pension reform is approved, will be needed.

35. Banks need to be further capitalized. Publicly announced recapitalizations for the systemic banks are a good start, but probably insufficient. The authorities should further tighten capital requirements and stand ready to inject public funds if private investors are not forthcoming. Higher capitalization will keep the banks' franchise value and contain the cost of borrowing.

36. Banks' governance should be improved, including by broadening the investor base. Expanding ownership to include private and foreign investors will help address long-standing governance and risk management weaknesses by reducing possible state interference in credit allocation. The authorities should set out clear divestment strategies and commit to their implementation.

37. Lending practices should not be distorted but monitored carefully. The proposal to tax banks' balance sheet to incentivize borrowing to the over-indebted corporate sector is distortive, and should not be implemented. Given ongoing risks to house prices and the prospect of rising interest rates, the authorities should take care to prevent recent surges in mortgage lending from creating new imbalances. The authorities' willingness to tighten prudential regulations if necessary is welcome.

38. Structural reforms in the labor and product markets are critical to boost potential growth, which has been lagging after the crisis. Labor market restrictionsespecially for dismissals - should be loosened. This, together with accelerating privatization and measures to enhance competition in product and financial markets, will help foster FDI inflows. Cancelling any remaining indexation of the minimum wage and eliminating the mandatory wage supplement for years of service would better align wage and productivity growth, helping avoiding a further degradation in unit labor cost.

39. It is proposed that the next Article IV consultation be held on the usual 24month cycle. 
Figure 1. Slovenia: Economic Indicators

After being hit by the crisis in 2009 , the economy is slowly recovering.

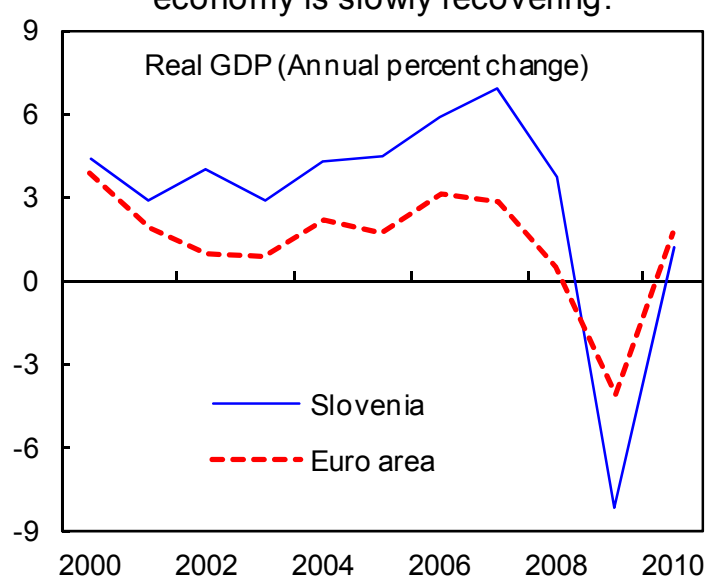

Net foreign demand has been the main factor driving the incipient recovery.

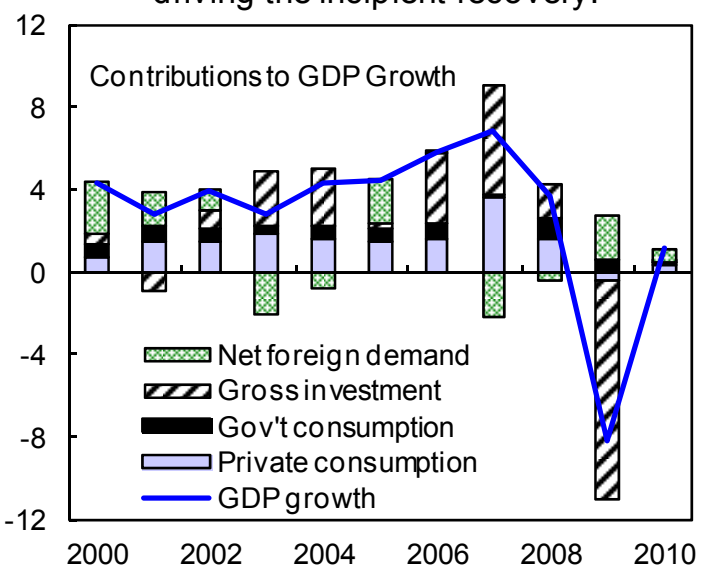

The weak domestic demand has helped CPI inflation to converge back to Euro area levels.

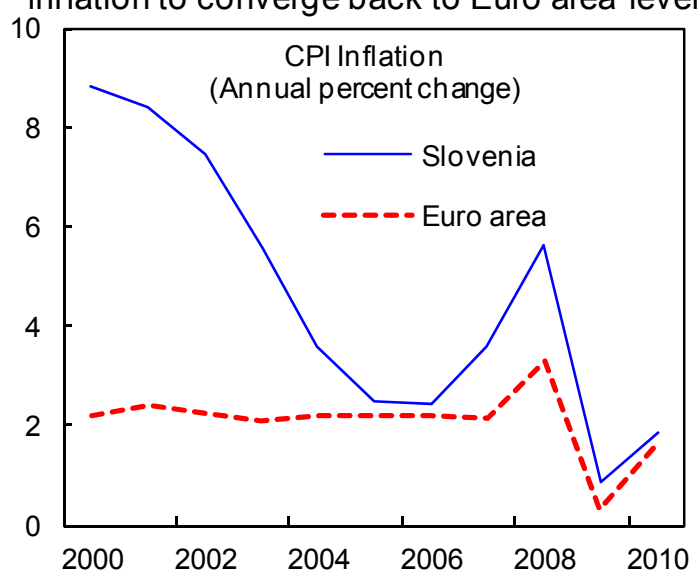

The output gap has remained negative as in the rest of the euro area.

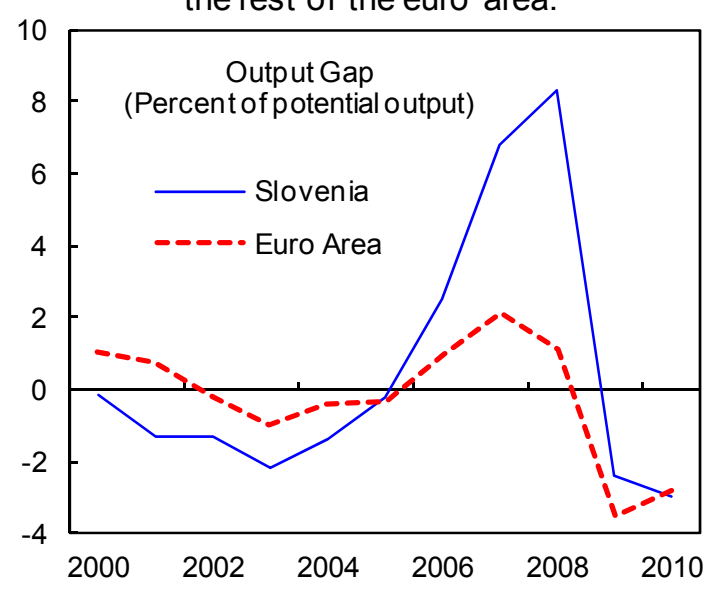

Permitting a recovery of the

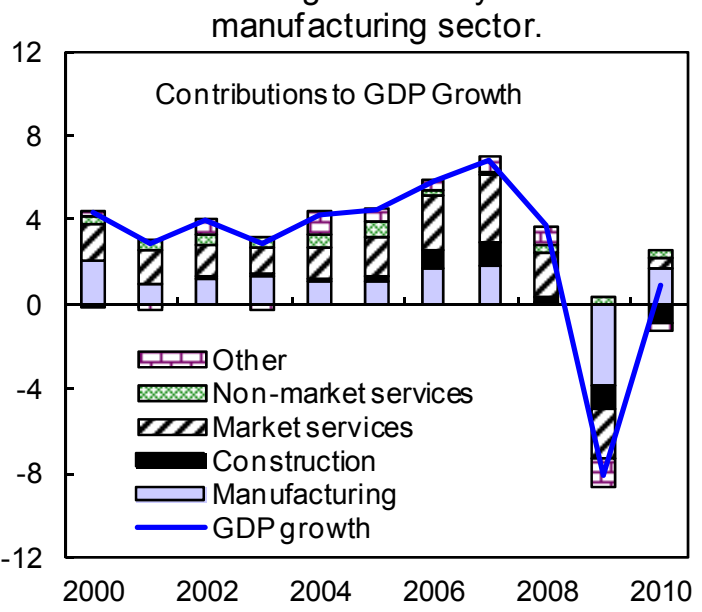

The deficit has narrowed in 2010 but weak

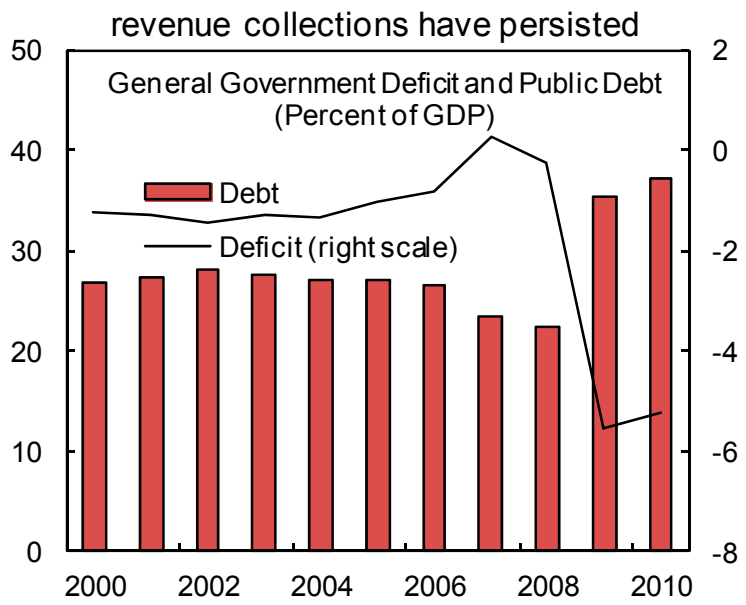

Sources: Bank of Slovenia; Ministry of Finance; Statistical Office; and IMF staff projections. 
Figure 2. Slovenia: Short-term Indicators (Year-on-year percent change, seasonally adjusted, unless otherwise indicated)

With some exceptions, confidence indicators have started to improve.

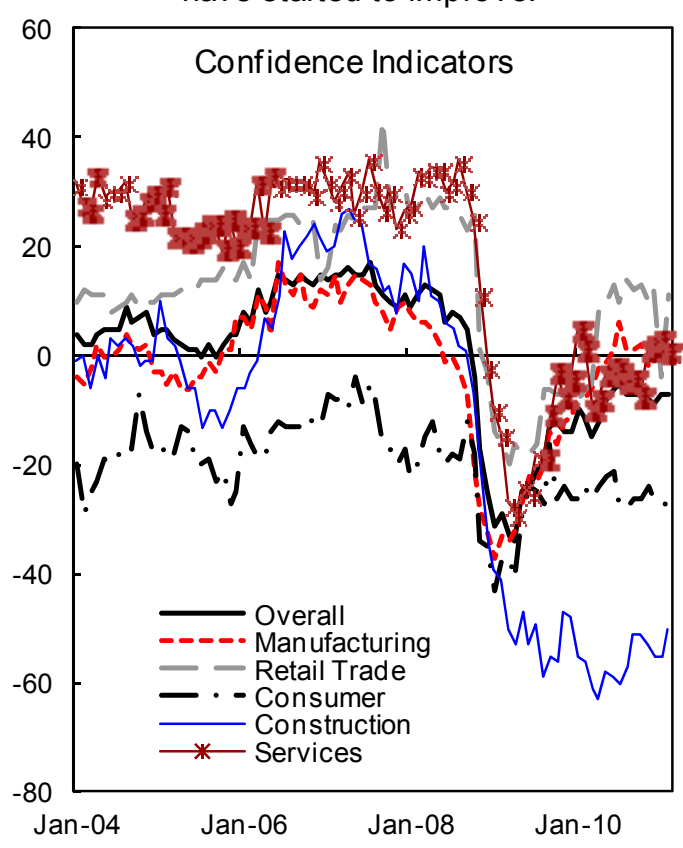

...and capacity utilization is increasing...

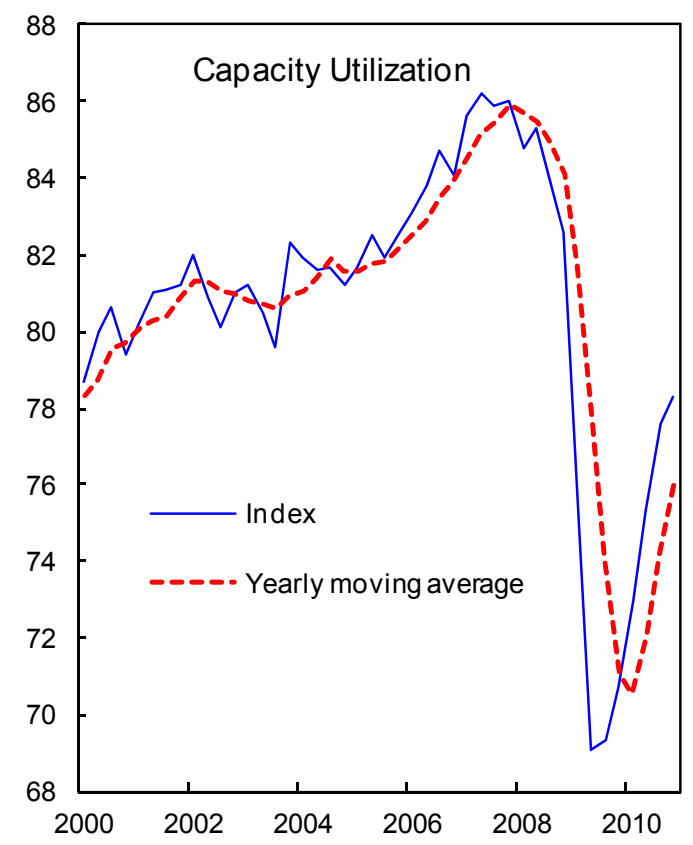

Industrial production is recovering...

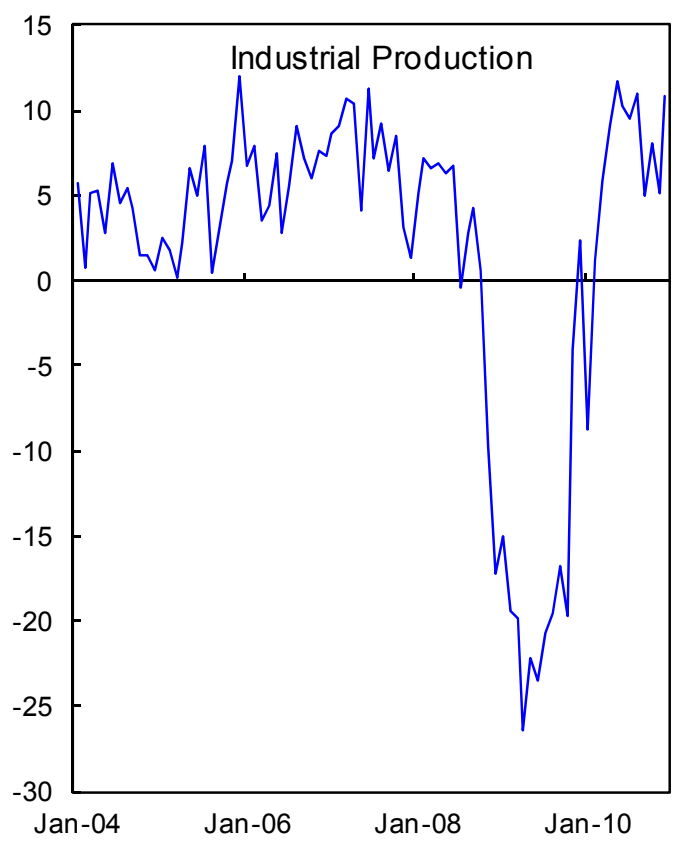

...reflecing the recovery in external demand.

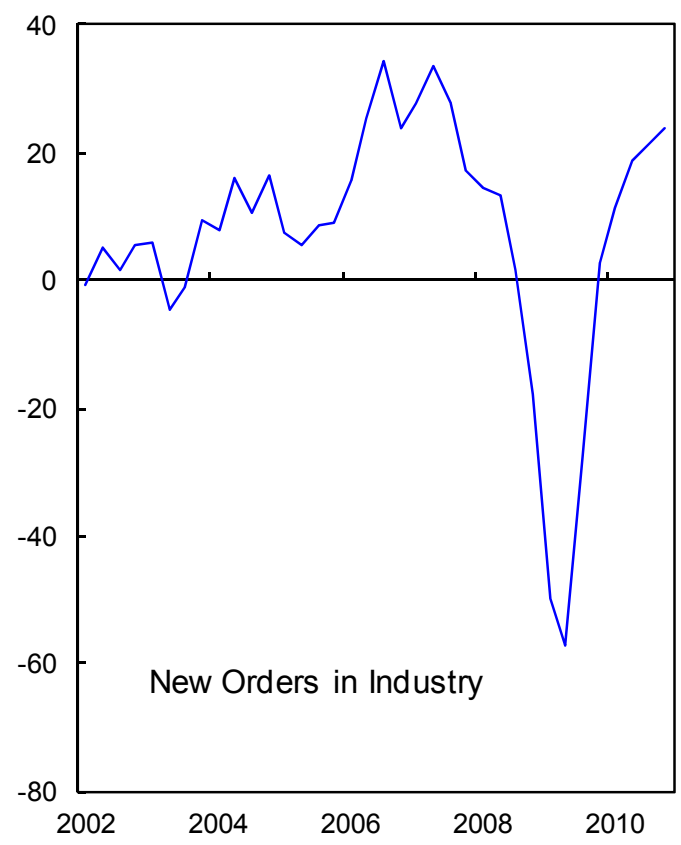

Sources: Statistical Office of the Republic of Slovenia; Euro pean Commission; and IMF staff estimates. 
Figure 3. Slovenia: Labor Market Indicators

Employment growth has sharply fallen since mid-2008 and remains depressed.

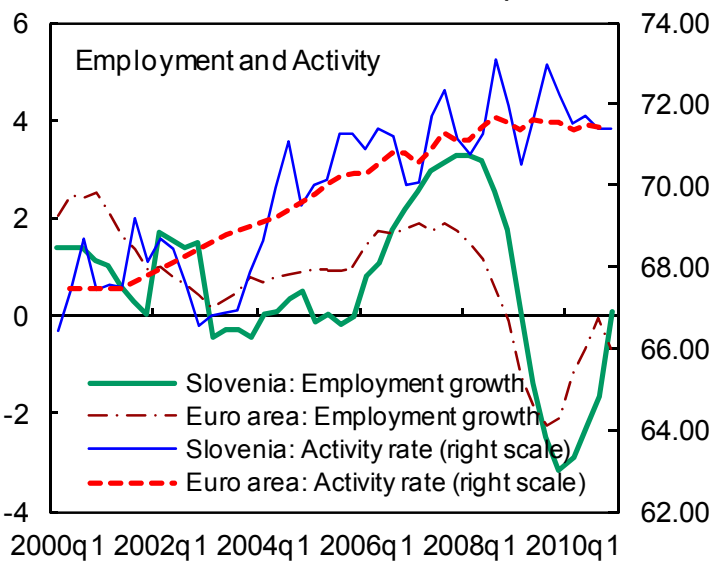

Unemployment has sharply increased.

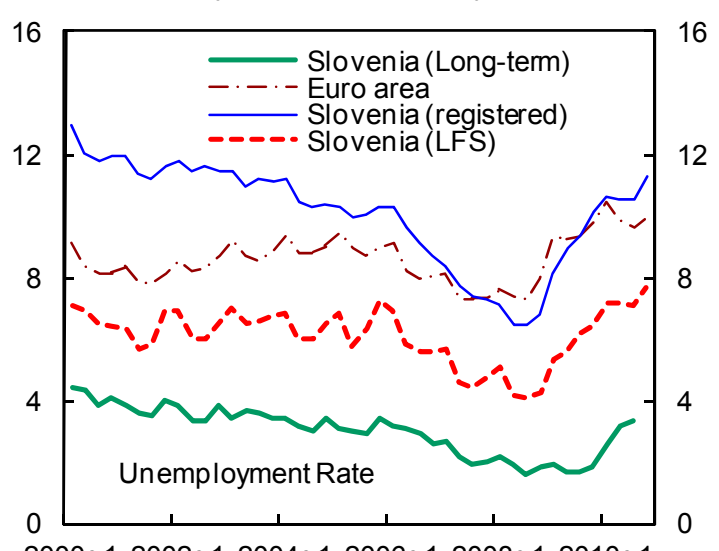

2000q1 2002q1 2004q1 2006q1 2008q1 2010q1

Labor productivity growth has fallen in most sectors, but particularly in manufacturing.

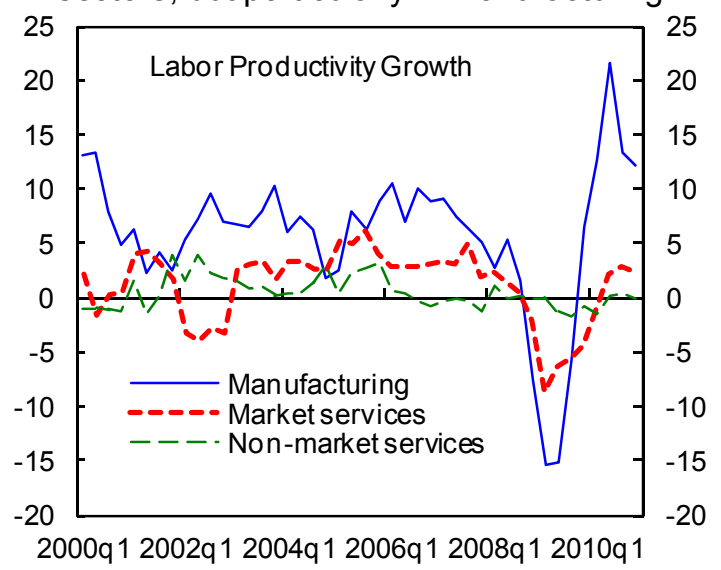

Employment in manufacturing has been particularly affected.

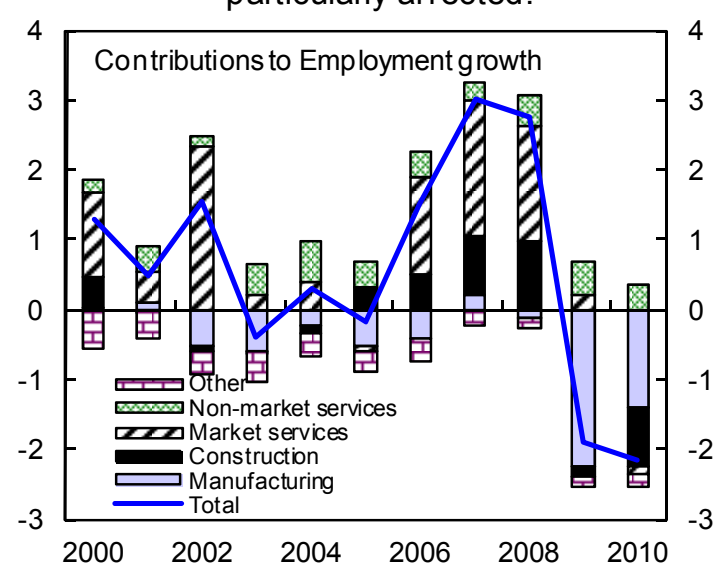

Nominal wages reacted with a lag and modestly to the fall in productivity, worsening

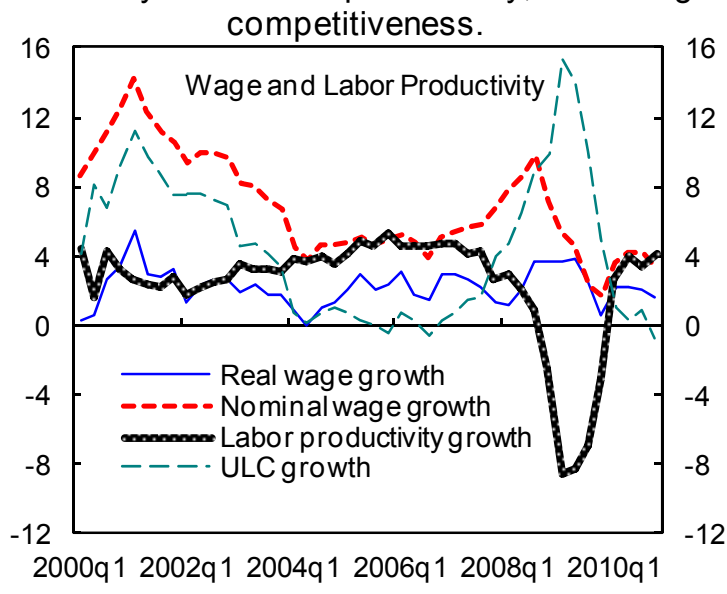

The increase in minimum wage led to a sharp increase in real manufacturing wage growth.

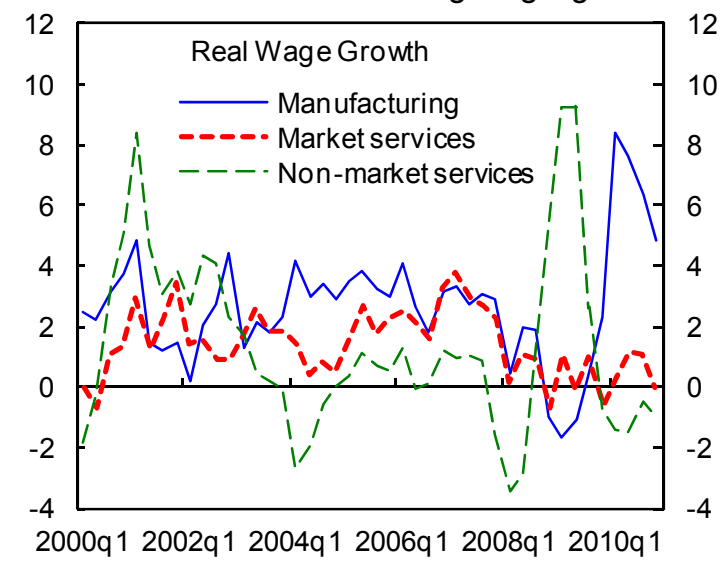

Sources: Statistical Office of the Republic of Slovenia; Eurostat; WEO; and IMF staff estimates. 


\section{Figure 4. Slovenia: CPI Inflation and Components (Year-on-year percent change)}

The pre-crisis inflation differential with the Euro area has been eliminated.

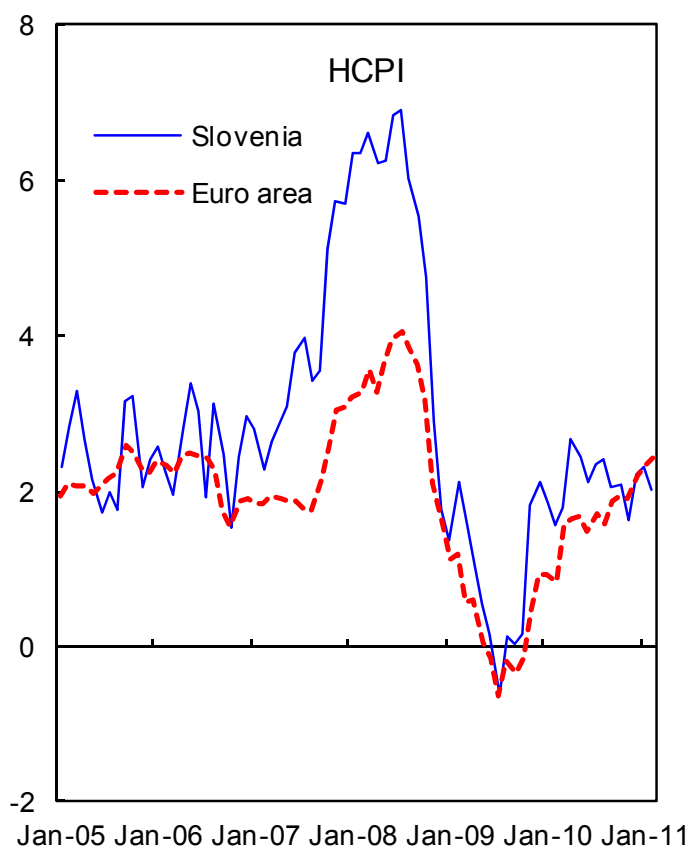

Increasing fuel,energy, and food prices contributed to the observed inflation in 2010 ...

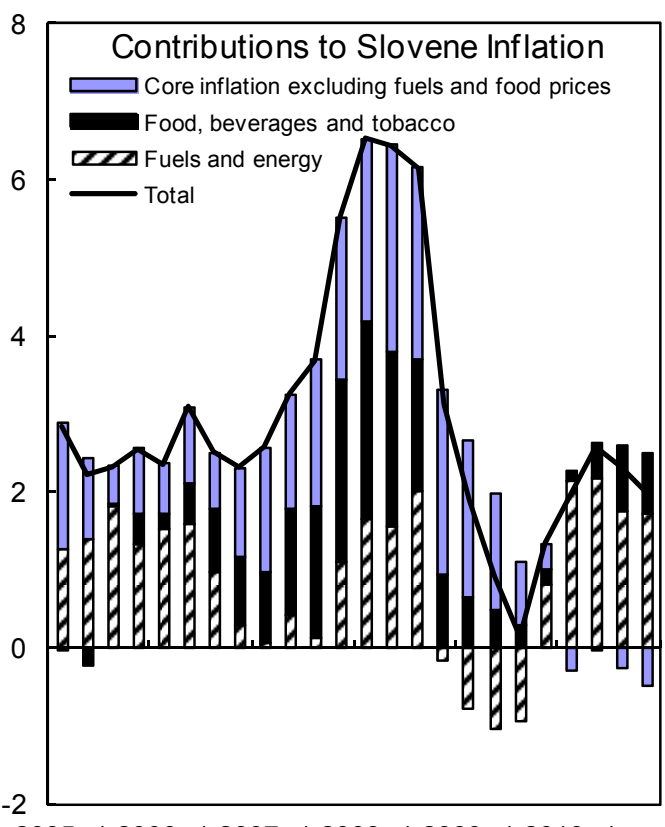

$2005 q 12006 q 1$ 2007q 1 2008q 1 2009q 1 2010q 1 due to a sharp decline in core inflation generated by weak domestic demand.

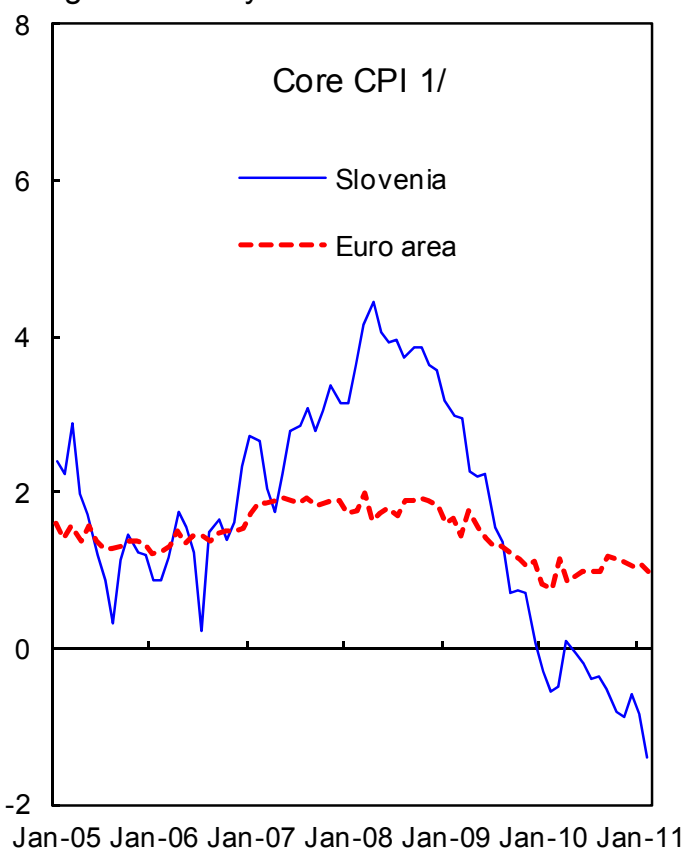

...given Slovenia's inflation high sensitivity to commodity price shocks.

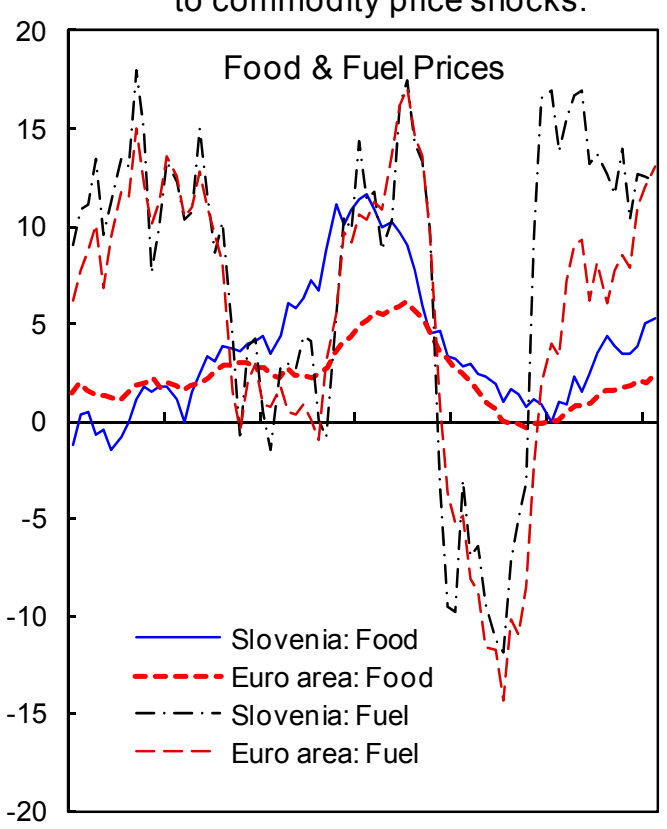

Jan-05 Jan-06 Jan-07 Jan-08 Jan-09 Jan-10 Jan-11

Sources: Eurostat; and IMF staff estimates.

1 / Core CPI is defined as total HCPI excluding energy, food, alcohol, and to bacco. 
Figure 5. Slovenia: Fiscal Sector (Percent of GDP)

The deficit widened in 2009 owing to automatic stabilizers and a discretionary stimulus package.

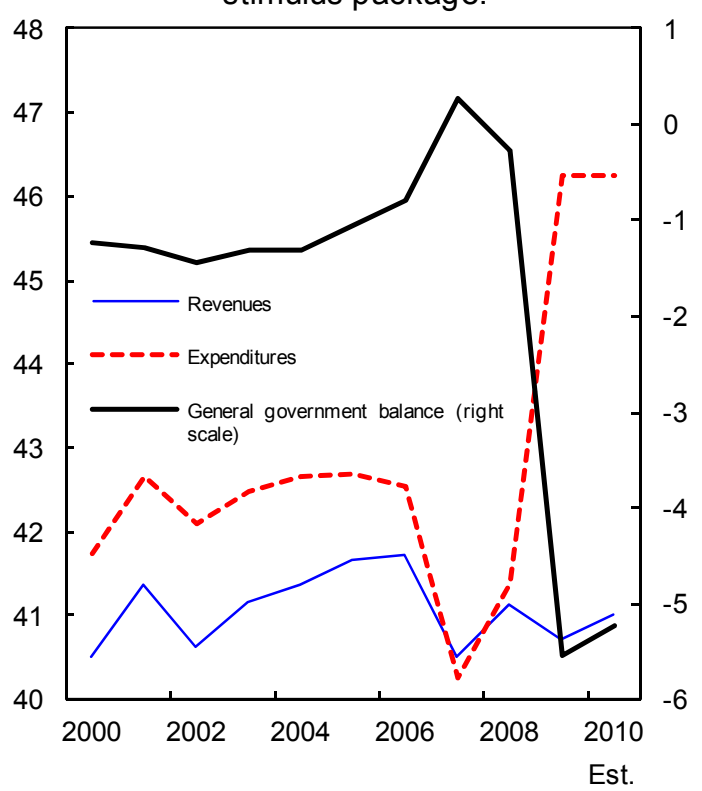

...and increased subsidies, while the wages, pensions and transfers dynamics are worrisome.

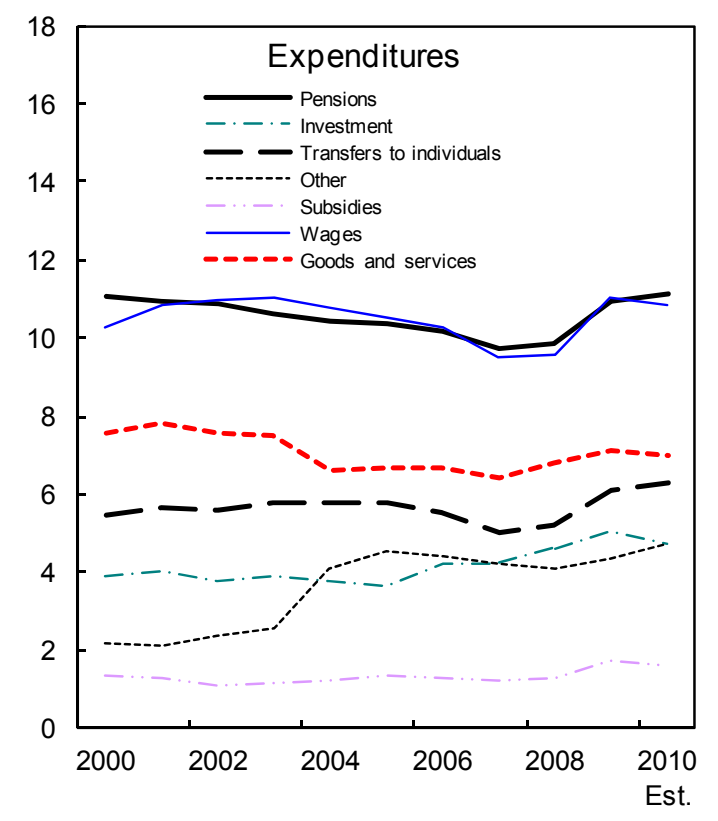

The discretionary stimulus package included a continuation of ongoing reduction in labor taxes...

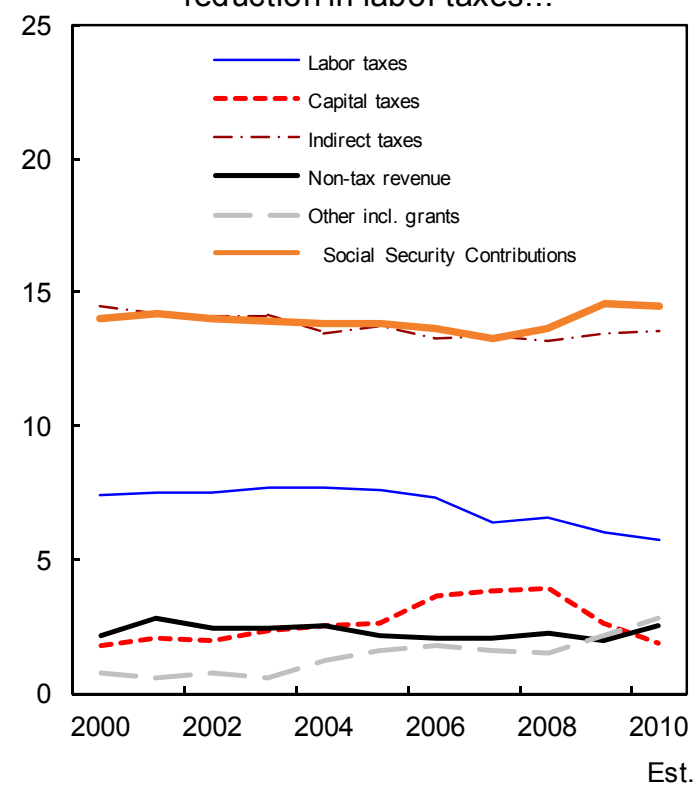

The fiscal impulse helped soften the drop in aggregate demand in 2009 and has been scaled back in 2010.

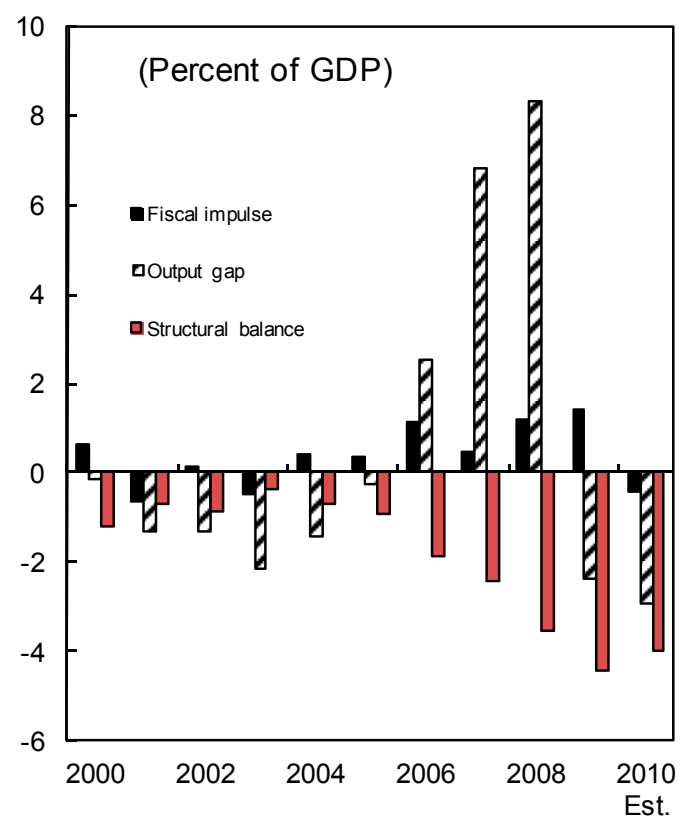

Sources: Ministry of Finance of the Republic of Slovenia; and IMF staff estimates. 
Figure 6. Slovenia: Public Debt Sustainability: Bound Tests 1/ (Public debt in percent of GDP)
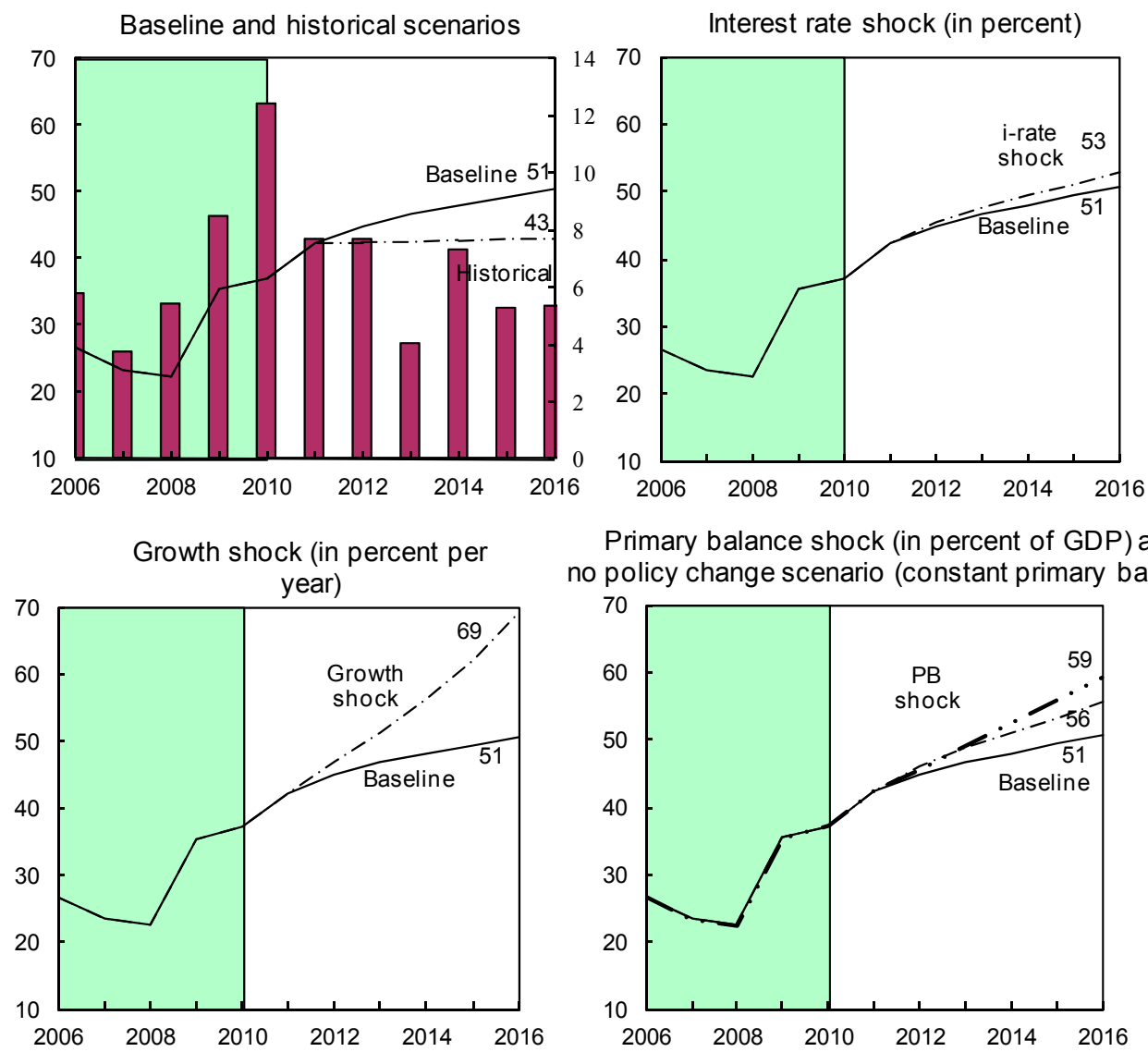

Primary balance shock (in percent of GDP) and no policy change scenario (constant primary balance)

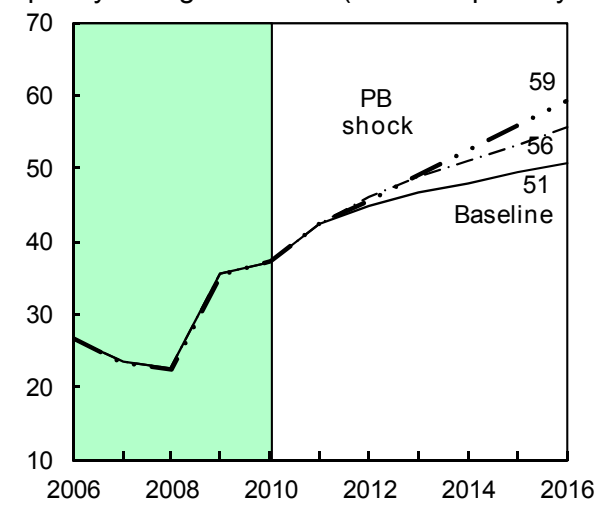

Combined shock 2/

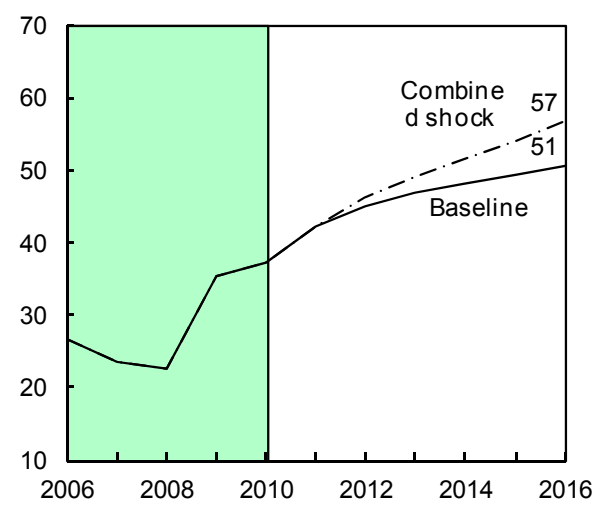

Real depreciation and contingent liabilities shocks 3/

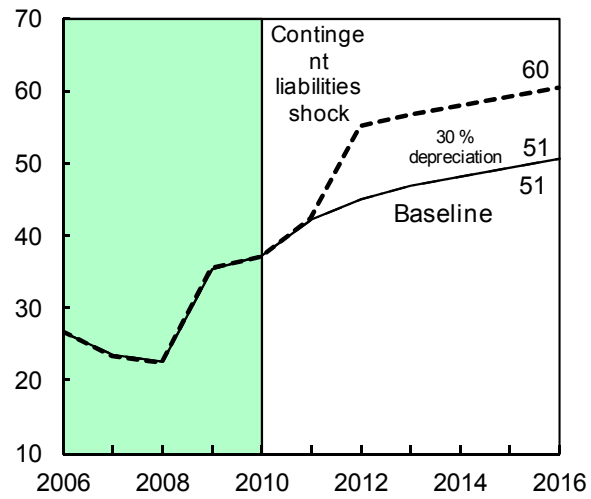

Sources: Intemational Monetary Fund, country desk data, and staff estimates.

$1 /$ Shaded areas rep resent actual data. Individual shocks are permanent one-half standard deviation shocks.

Figures in the boxes represent average p rojections for the respective variables in the baseline and scenario being presented. Ten-year historical average for the variable is al so shown.

2/ Permanent $1 / 4$ standard deviation shocks ap plied to real interest rate, growth rate, and primary balance.

$3 /$ One-time real depreciation of 30 percent and 10 percent of GDP shock to contingent liabilities occur in 2010 ,

with real depreciation defined as nominal depreciation (measured by percentage fall in dollar value of local currency) minus domestic inflation (based on GDP deflator). 


\section{Figure 7. Slovenia: Monetary Conditions \\ (Percent, unless otherwise indicated)}

The sharp fall in inflation has only partially been reflected in real interest rates...

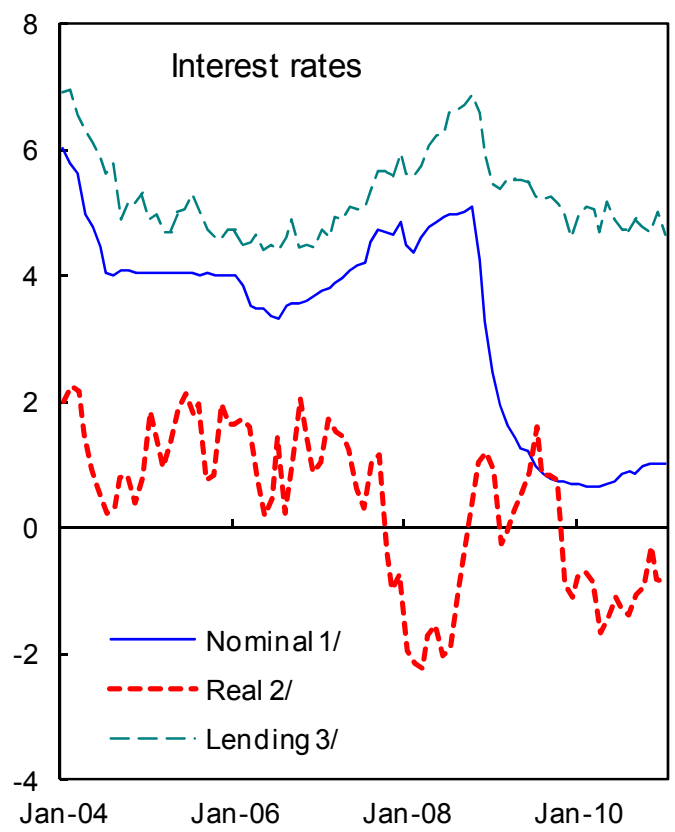

...while reversing part of the real exchange rate appreciation pre-crisis.

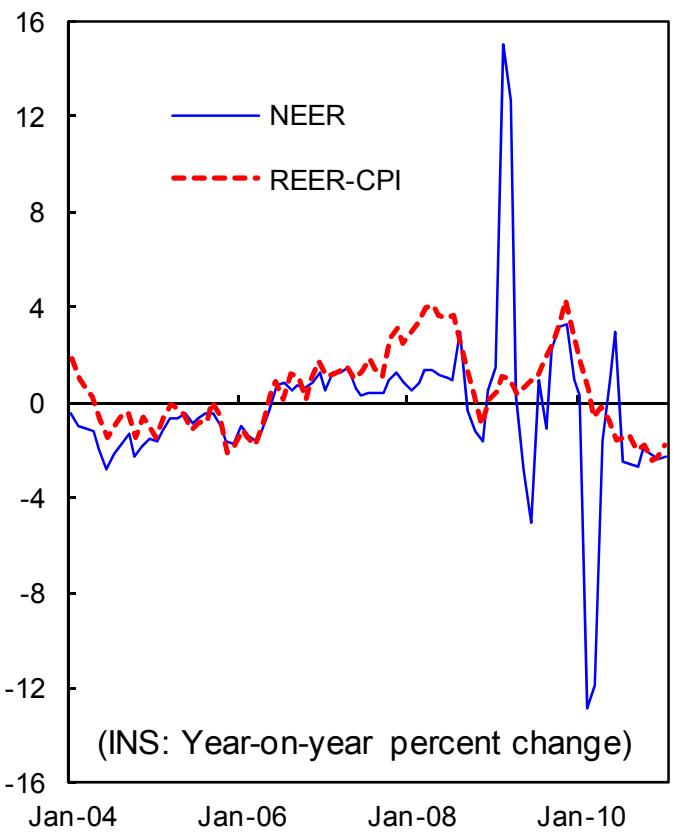

Credit growth to the private sector has collapsed and remains limited.

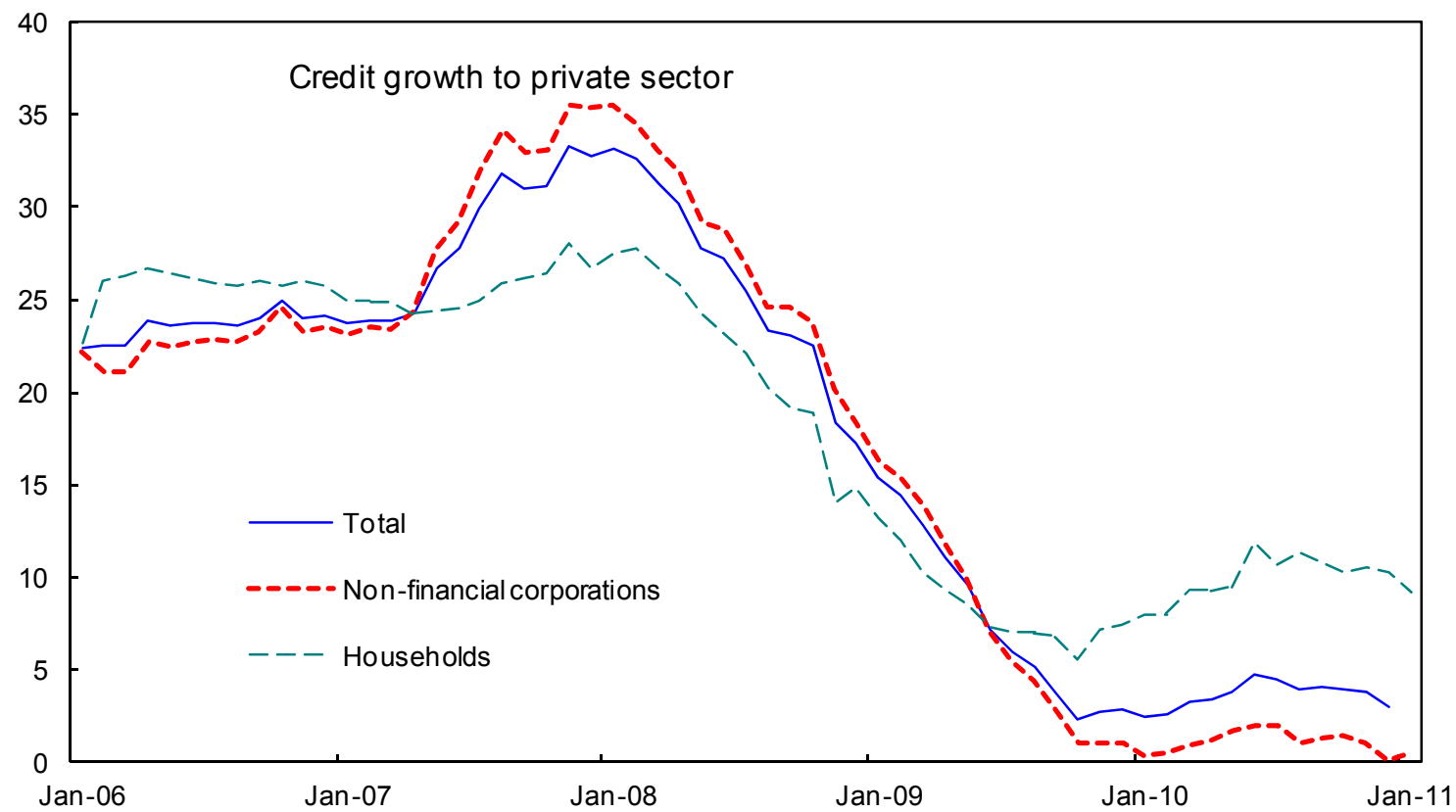

Sources: Bank of Slovenia; and IMF staff estimates. $1 /$ SITIBOR / EURIBOR 3 month interest rate.

2/ Nominal 3-month interest rate deflated by HCPI year-on-year percent change.

$3 /$ Floating and up to 1 year initial rate fixation on loans over 1 million euro. 
Figure 8. Slovenia: High-Frequency Financial Indicators 1/

Banking shares failed to recover...

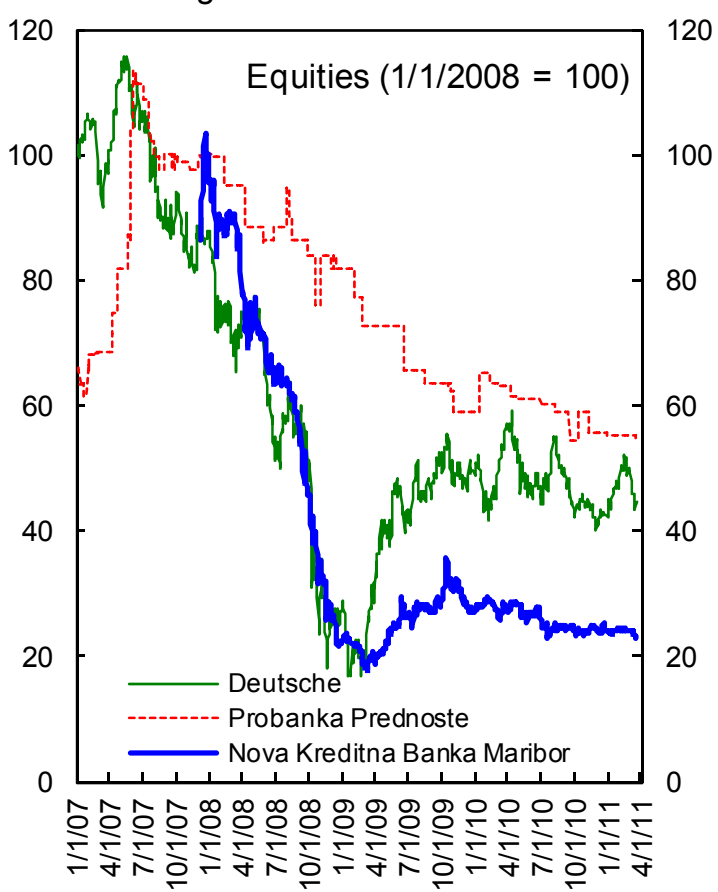

Interest rates remain low...

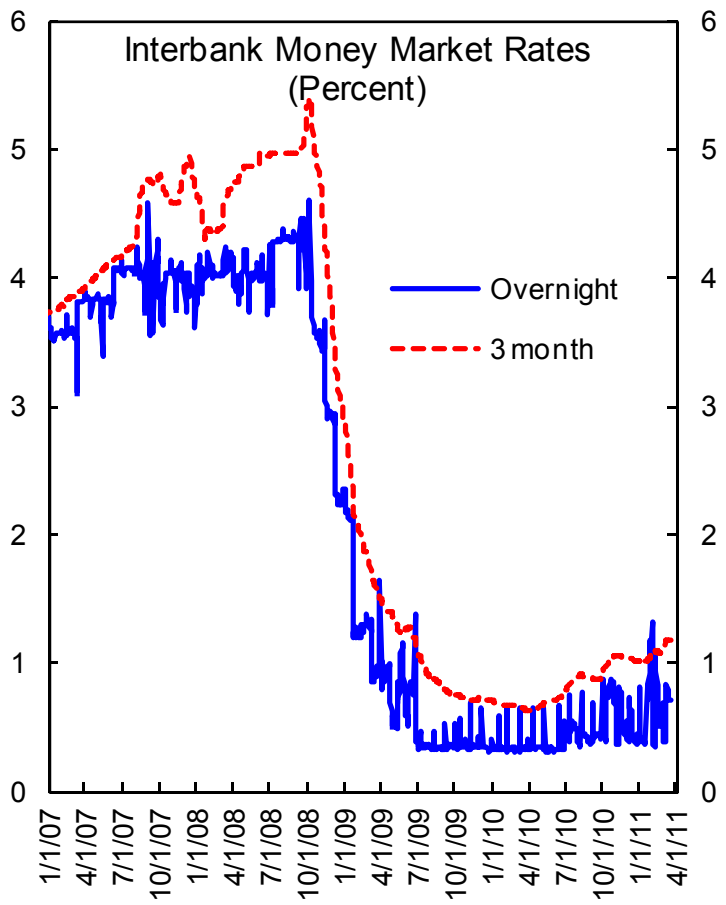

... as did the broad stock index.

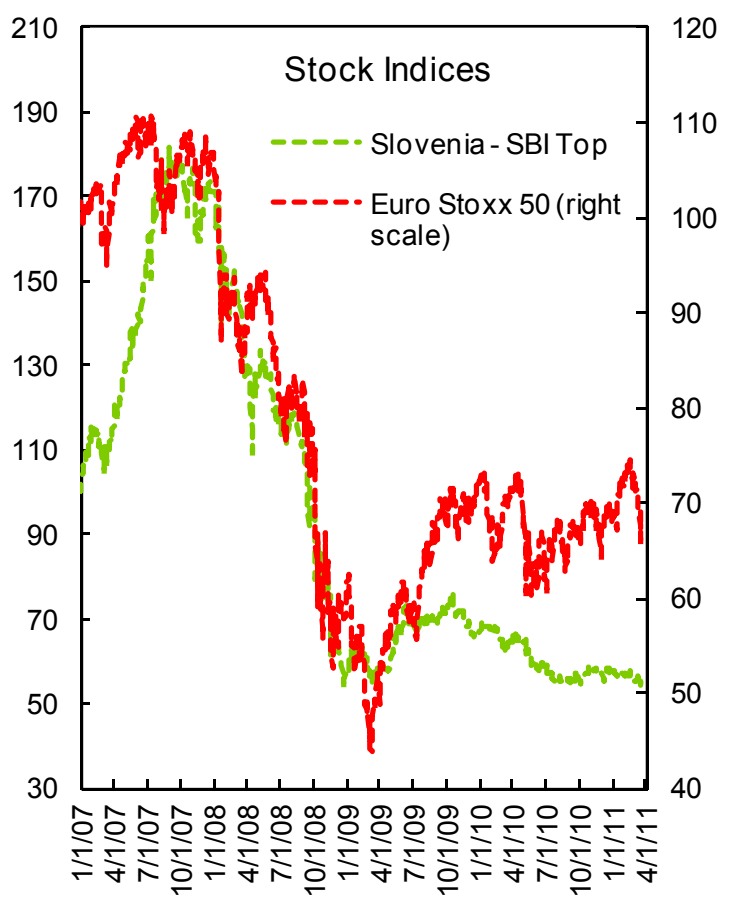

120

110

100

90

80

70

60

50

40

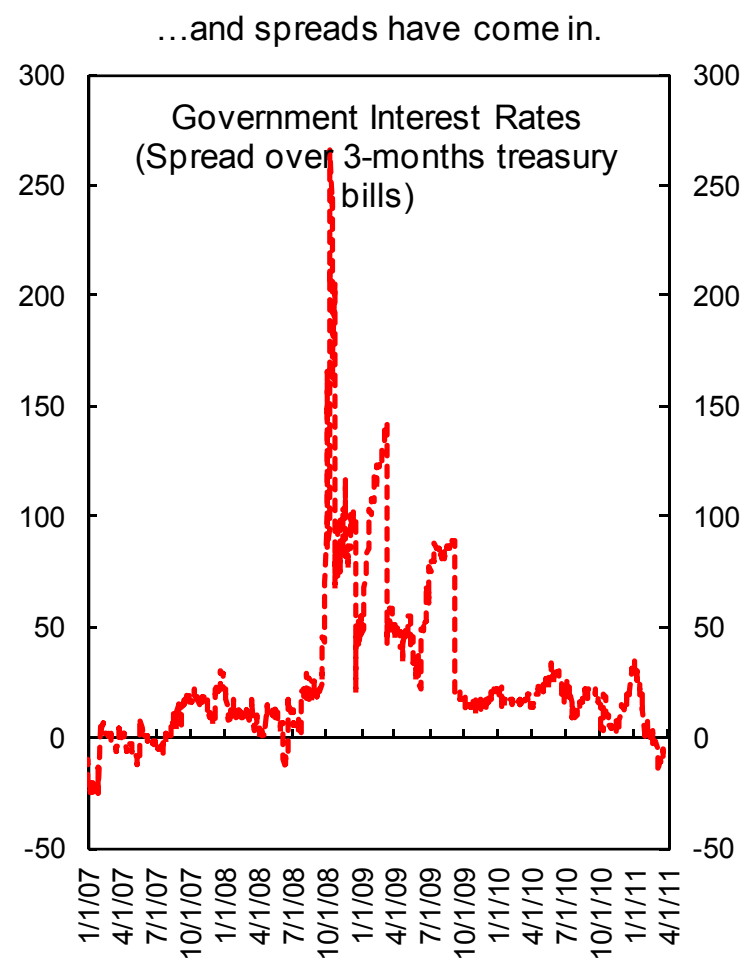

Sources: Thomson Financial/DataStream; and Bloomberg 1/The latest observation is as of March 21, 2011. 
Figure 9. Slovenia: External Sector Developments

The trade and current account deficits have narrowed substantially during the crisis.

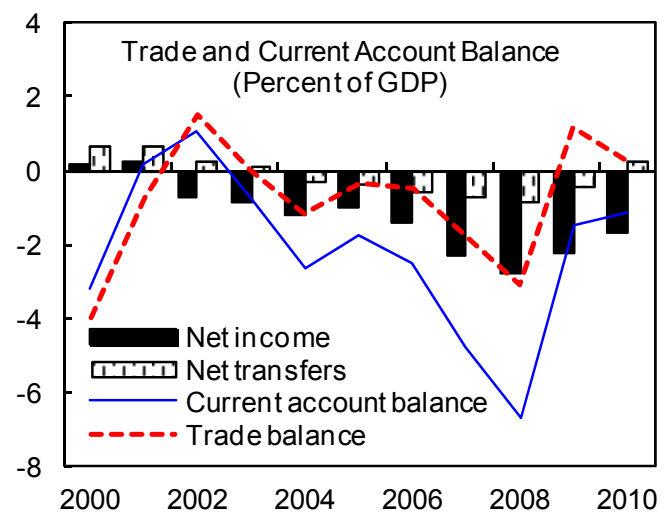

Despite some crisis-related improvement..

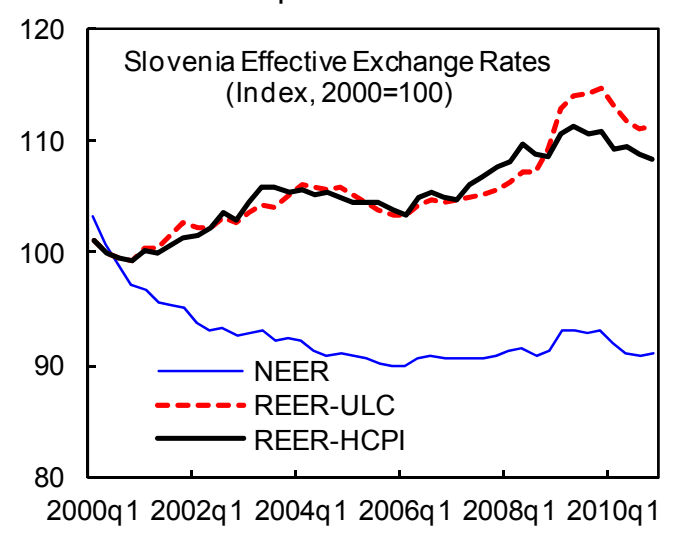

Market shares have been broadly constant.

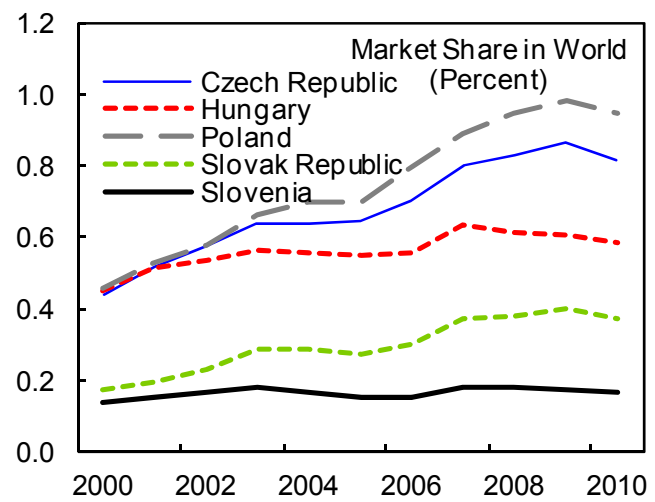

As goods imports declined more than goods exports.

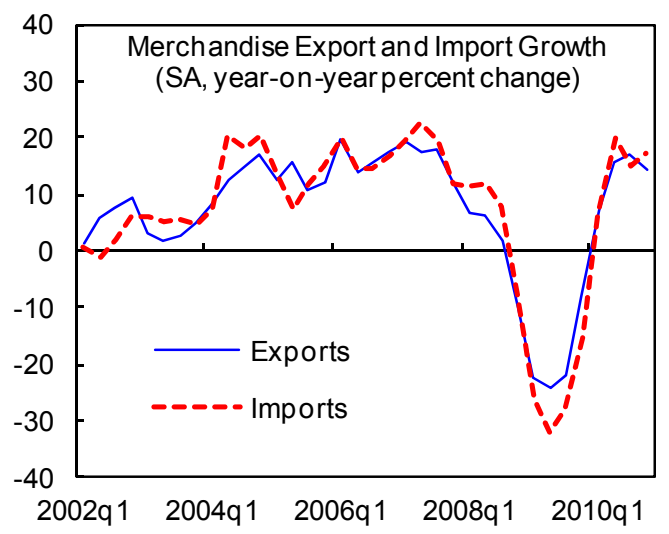

...Slovenia's cost competitiveness deteriorated much more than in main trading

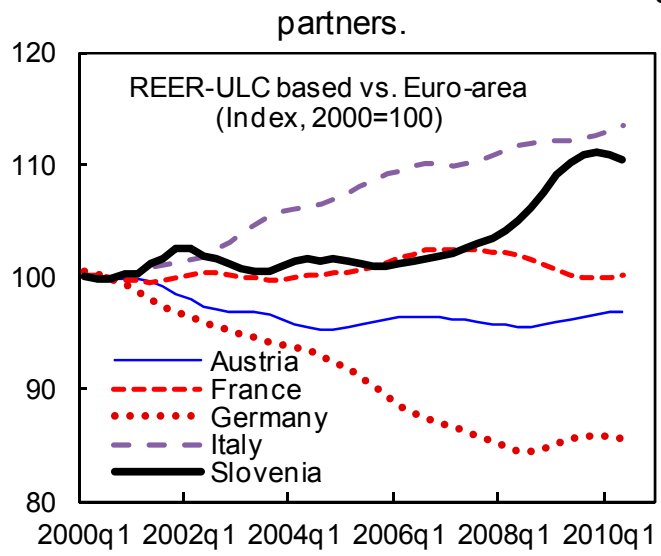

The large current account deficit reduction mirrored a reversal in cross-border lending flows.

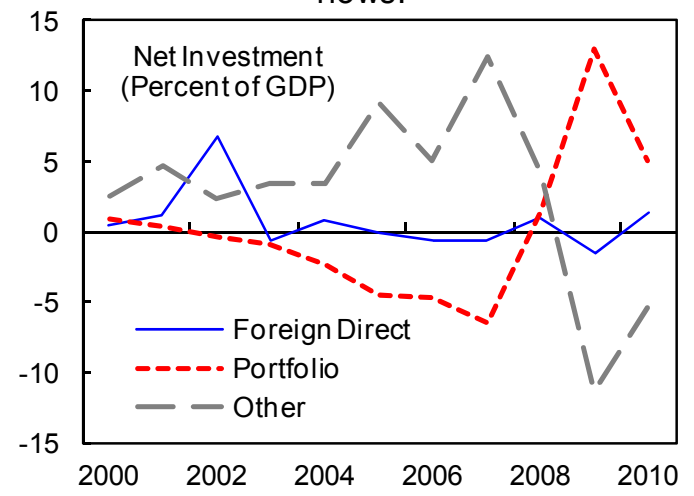

Sources: Bank of Slovenia; European Central Bank; Direction of Trade Statistics; and IMF staff estimates. 
Figure 10. Slovenia: External Debt Sustainability: Bound Tests 1/ (External debt in percent of GDP)
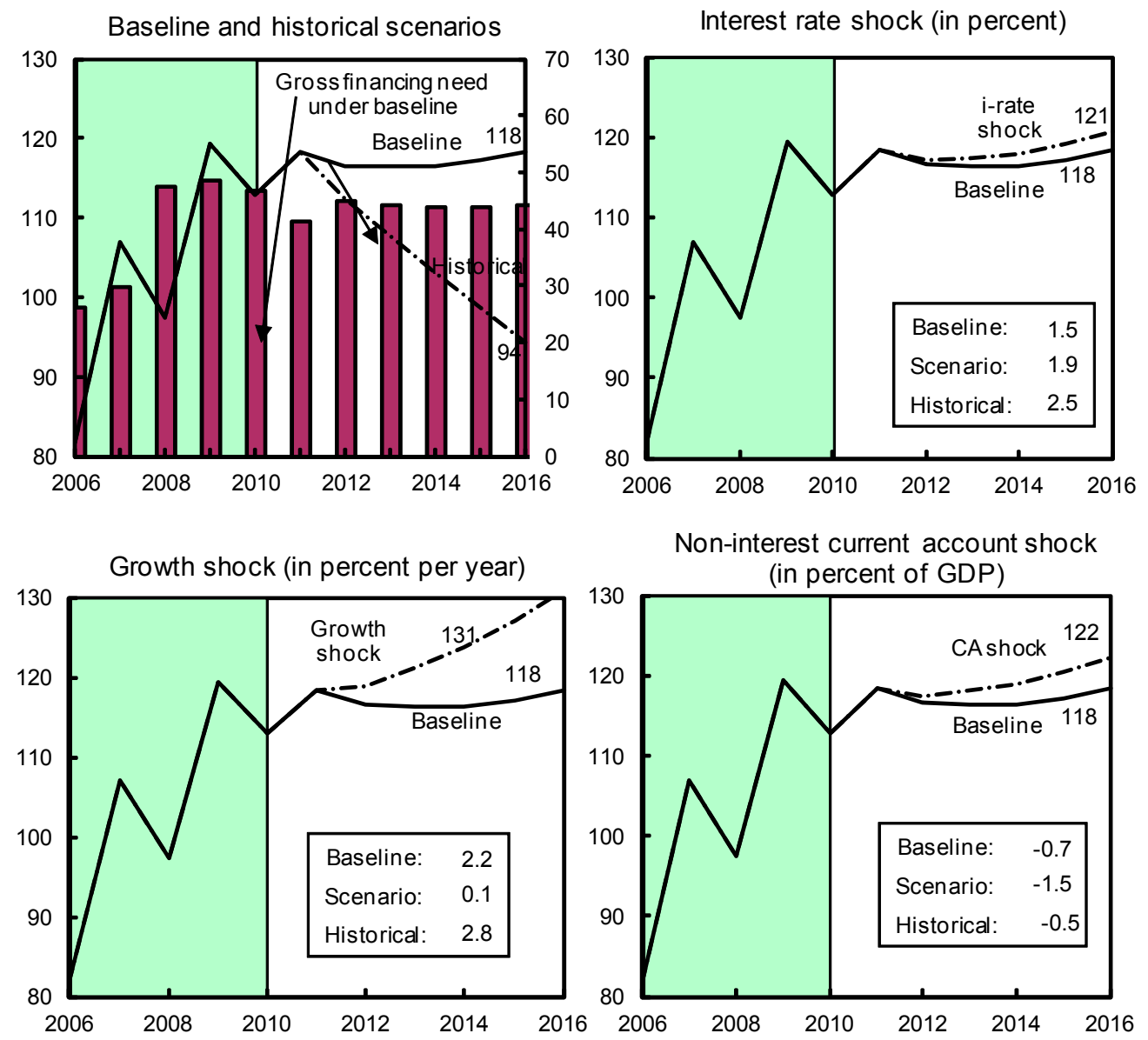

Non-interest current account shock

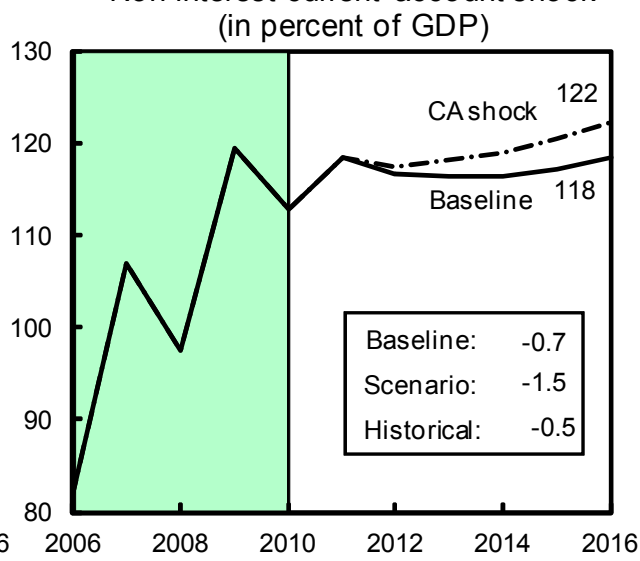

Combined shock 2/
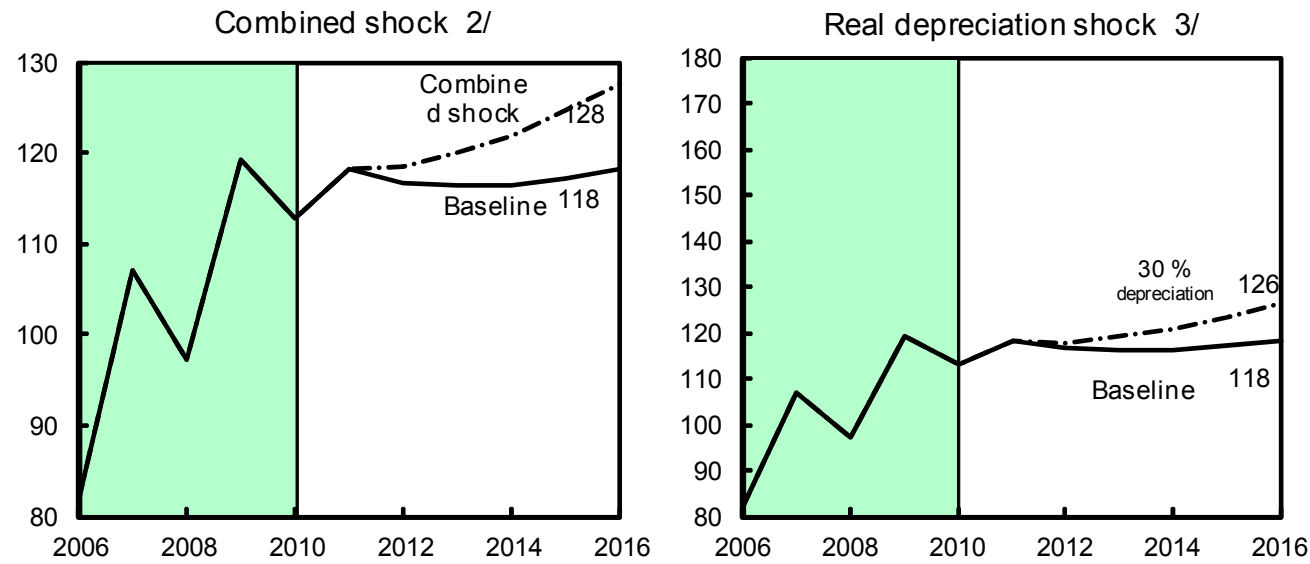

Sources: International Monetary Fund, Country desk data, and IMF staff estimates.

$1 /$ Shaded areas represent actual data. Individual shocks are permanent one-half standard deviation shocks. Figures in the boxes representaverage projections for the respective variables in the baseline and scenario being presented. Ten-year historical average for the variable is also shown. $2 /$ Permanent $1 / 4$ standard deviation shocks applied to real interest rate, growth rate, and current accountbalance.

3/One-time real depreciation of 30 percent occurs in 2010. 
Figure 11. Slovenia: Financial Soundness Indicators, 2010 1/

(Percent)

Banks are thinly capitalized as can be seen by low tier-1 ratios ...
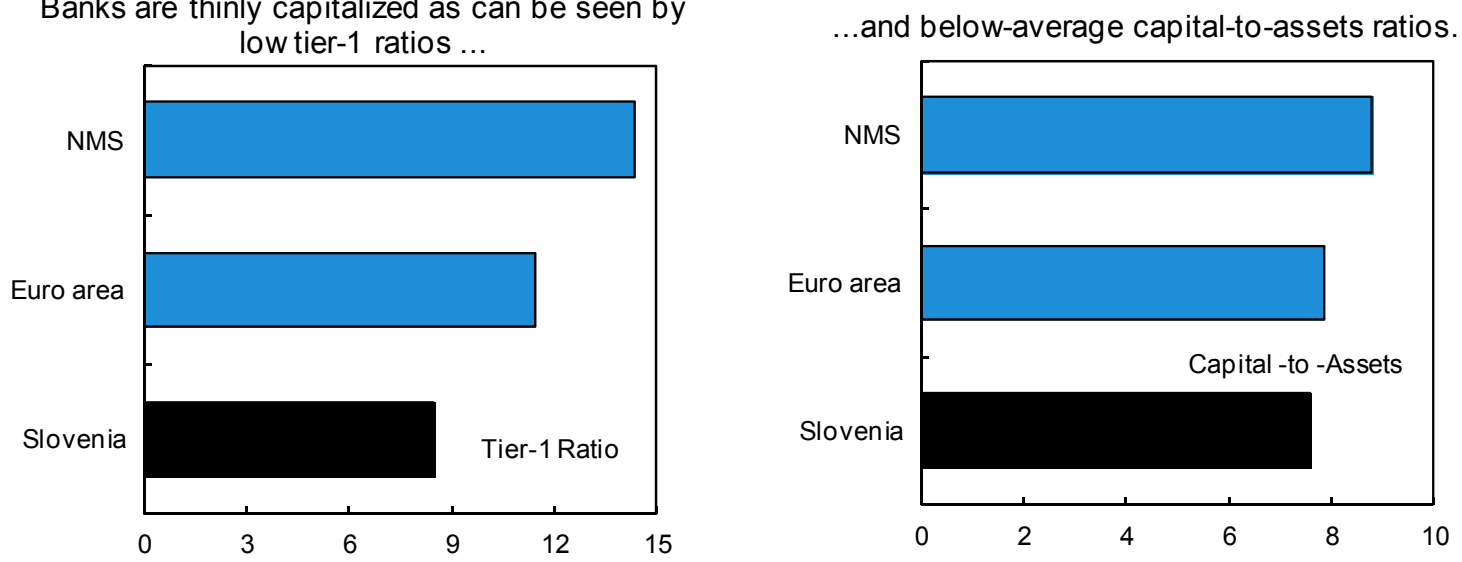

Non-performing loans remain relatively low, but have increased rapidly.

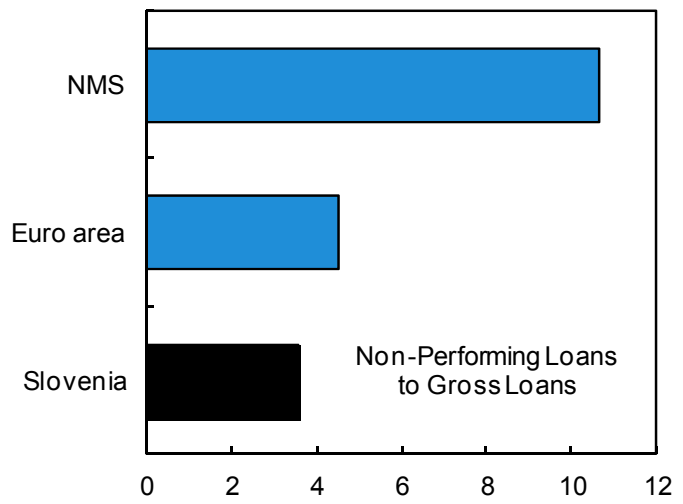

Return on assets is depressed following the end of the credit boom...

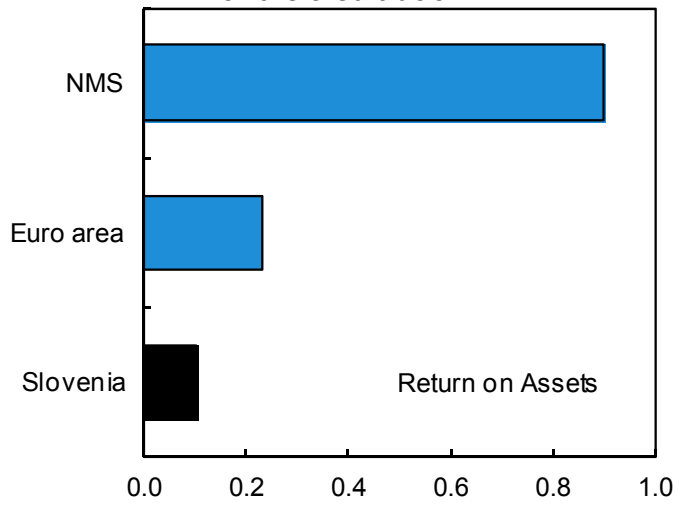

Sources: European Central Bank: IMF, Global Financial Stability Report; and Bank of Slovenia. 1/NMS includes: Czech Republic, Estonia, Hungary, Latvia, Lithuania, Poland, and Slovak Republic. 
Figure 12. Bank Credit to Households and Nonfinancial Corporations in European Emerging Markets, 2009

Bank credit to non-financial corporates is high relative to Slovenia's level income...

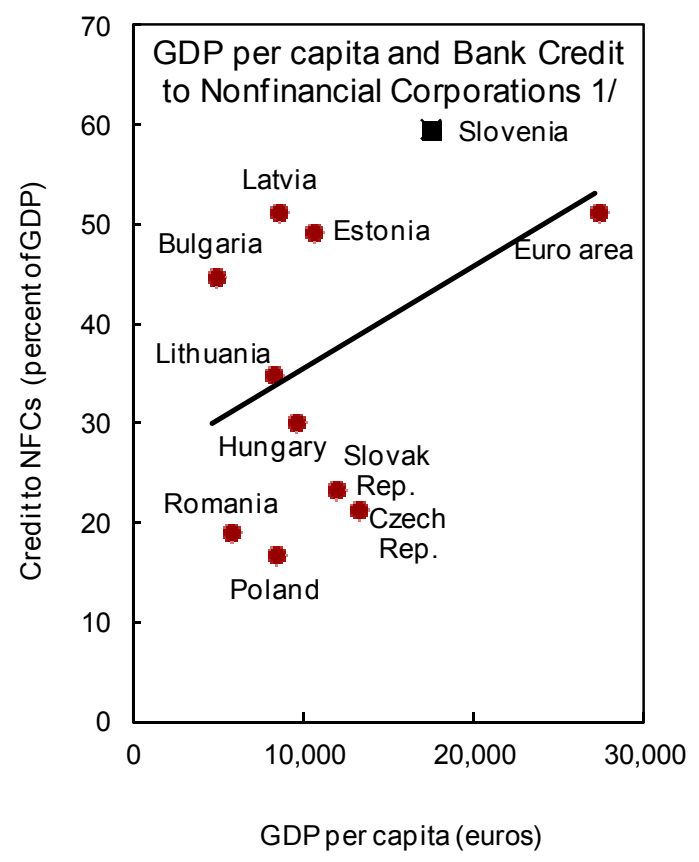

Bank credit is the only significant source of external financing for non-financial corporates...

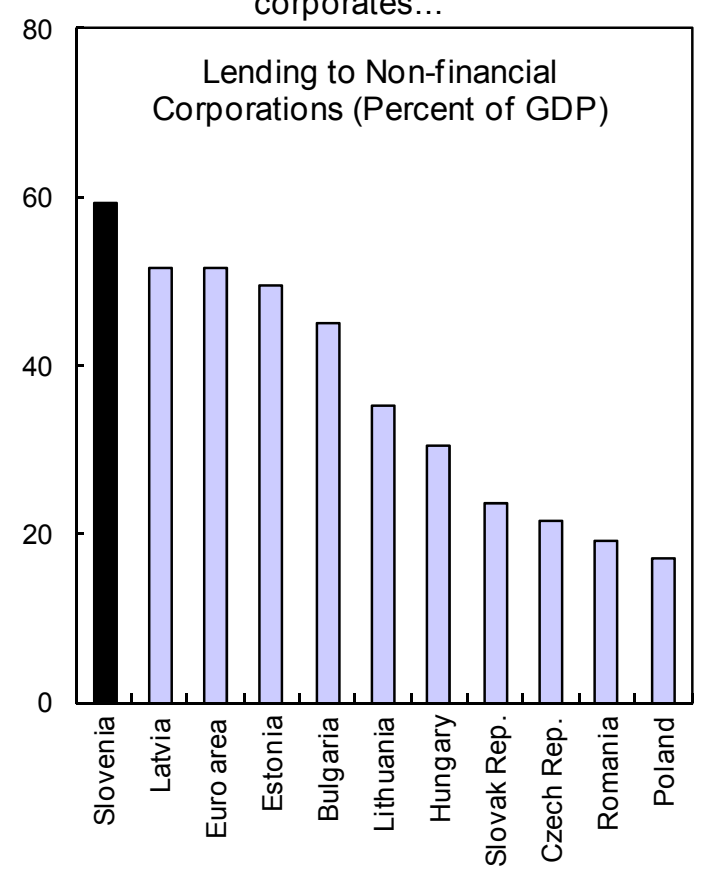

...while houshold credit is lower than income alone would suggest.

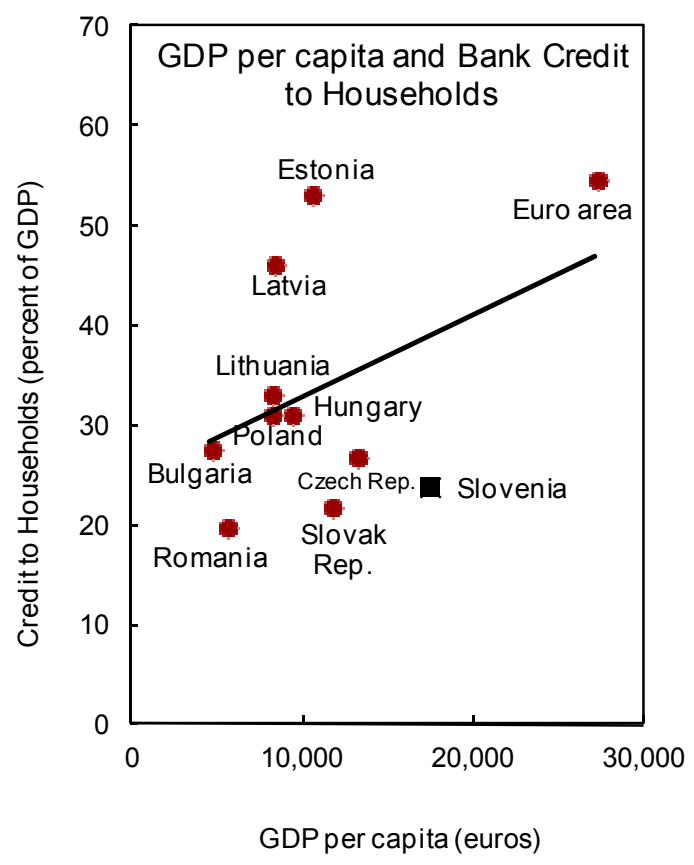

...but households do not overly rely on borrowing from banks.

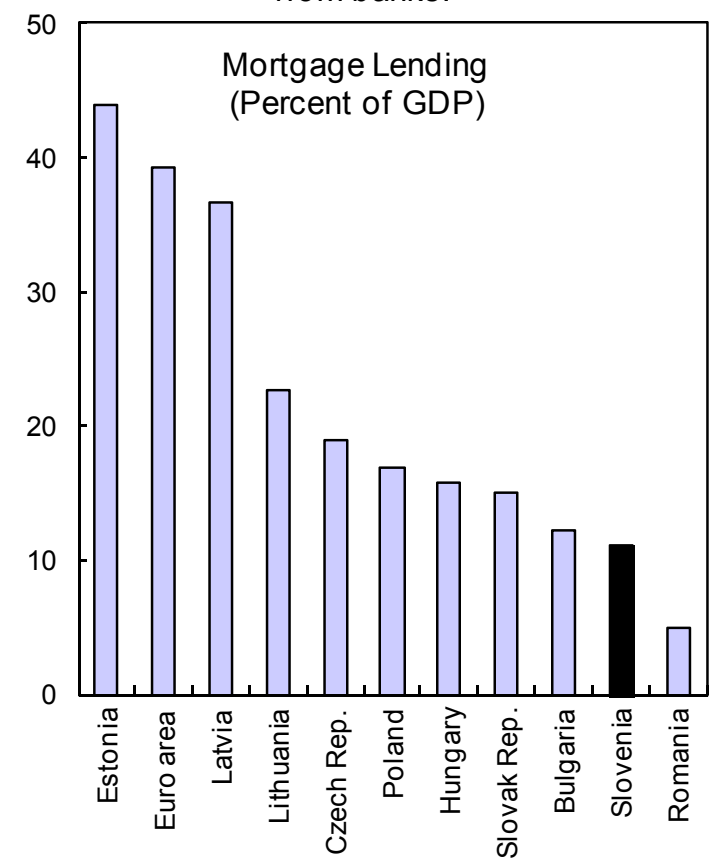

Sources: Eurostat; European Central Bank; and IMF staff estimates. 
Figure 13. Structural Indicators of the Product Market

Foreign direct investment into Slovenia has been very limited.

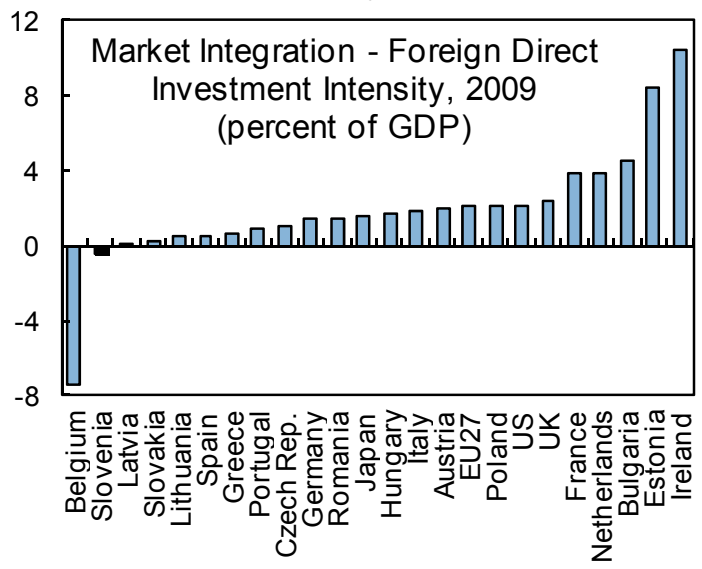

Slovenia ranks low among EU countries on global competitiveness Index.

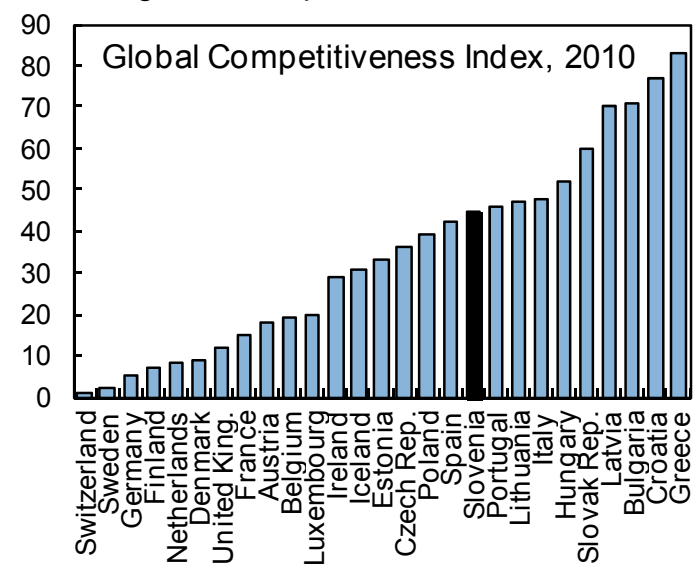

Partly as a result of these factors, Slovenia has been lagging in technological upgrading.

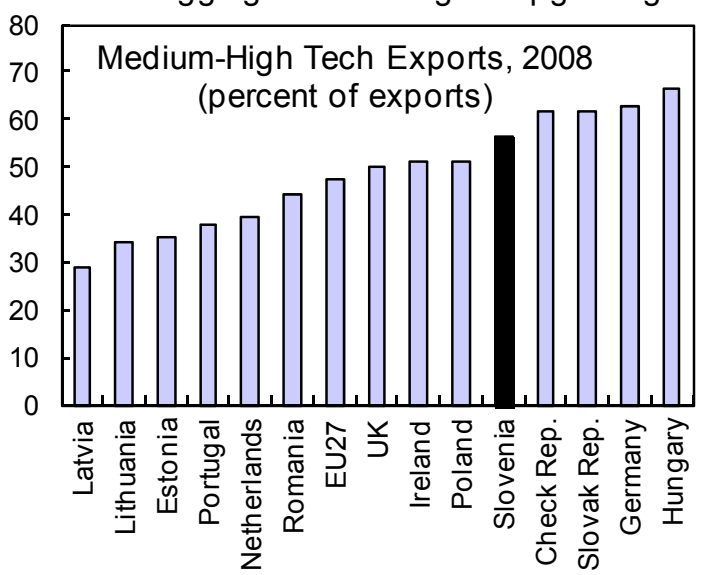

Product market regulations are more restrictive than in most of EU countries.

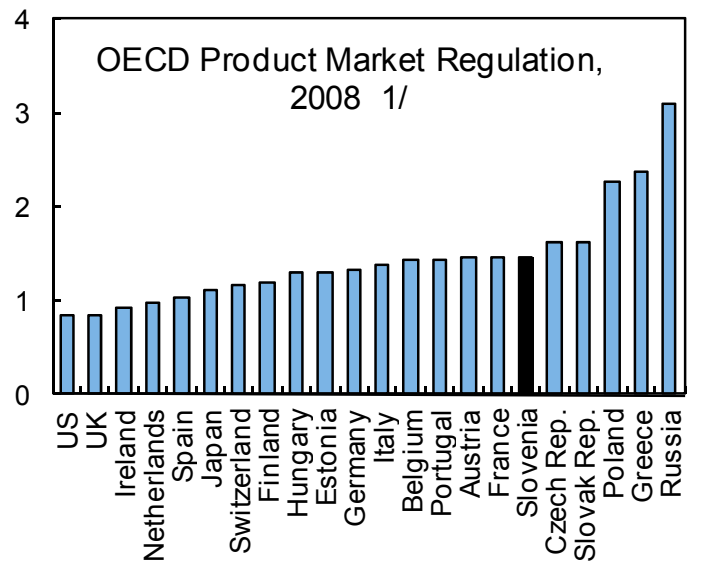

Slovenia also performs poorly on indicators of ease of doing business.

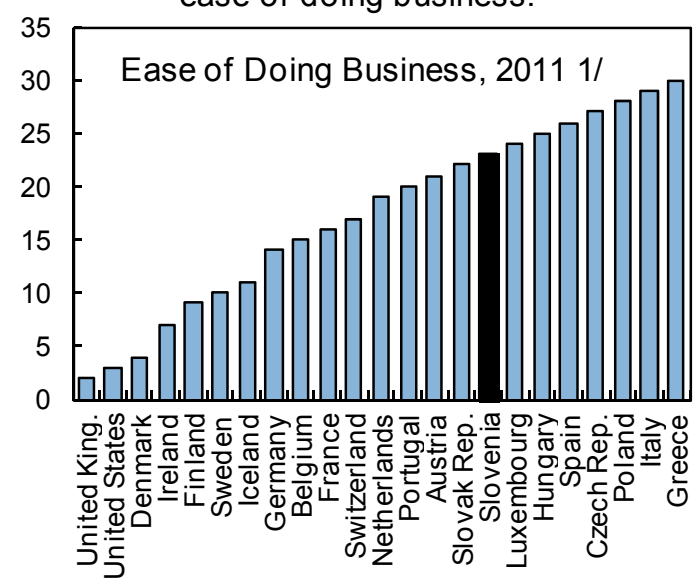

Innovation outcomes have fallen short of the relatively high investment in R\&D spending.

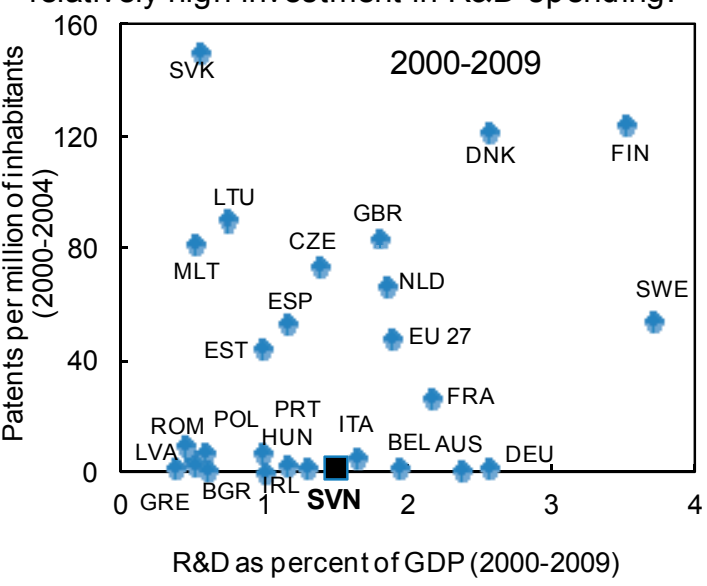

Sources: World Bank, Doing Business; World Economic Forum; European Commission, European Innovation Scoreboard. $1 /$ A lower value indicates a better performance. 
Table 1. Slovenia: Selected Economic Indicators, 2006-2013

(Annual percentage change, unless noted otherwise)

\begin{tabular}{|c|c|c|c|c|c|c|c|c|}
\hline & \multirow[b]{2}{*}{2006} & \multirow[b]{2}{*}{2007} & \multirow[b]{2}{*}{2008} & \multirow[b]{2}{*}{2009} & \multirow[b]{2}{*}{2010} & \multicolumn{3}{|c|}{ Projections } \\
\hline & & & & & & 2011 & 2012 & 2013 \\
\hline Real GDP & 5.9 & 6.9 & 3.7 & -8.1 & 1.2 & 2.0 & 2.4 & 2.5 \\
\hline Domestic demand & 5.7 & 8.9 & 4.1 & -10.1 & 0.4 & 1.0 & 2.2 & 2.6 \\
\hline Private consumption & 2.9 & 6.7 & 2.9 & -0.8 & 0.5 & 1.2 & 2.2 & 2.3 \\
\hline Public consumption & 4.0 & 0.7 & 6.2 & 3.0 & 0.8 & -2.4 & -1.0 & 0.7 \\
\hline Gross capital formation & 12.2 & 18.2 & 4.9 & -32.0 & 0.0 & 3.5 & 4.5 & 4.6 \\
\hline Net exports (contribution to growth) & 0.1 & -2.2 & -0.5 & 2.2 & 0.7 & 1.0 & 0.2 & -0.1 \\
\hline Exports of goods and services & 12.5 & 13.7 & 3.3 & -17.7 & 7.8 & 6.8 & 5.7 & 5.5 \\
\hline Imports of goods and services & 12.2 & 16.7 & 3.8 & -19.7 & 6.6 & 5.3 & 5.4 & 5.6 \\
\hline Output gap (in percent of potential GDP) & 2.5 & 6.8 & 8.3 & -2.4 & -3.0 & -2.6 & -2.0 & -1.1 \\
\hline \multicolumn{9}{|l|}{ Prices } \\
\hline GDP deflator & 2.0 & 4.2 & 4.0 & 3.2 & 0.7 & 0.7 & 2.7 & 2.4 \\
\hline Consumer prices (national definition, period average) & 2.5 & 3.6 & 5.7 & 0.9 & 1.8 & 2.2 & 3.1 & 2.3 \\
\hline HICP (period average) & 2.5 & 3.8 & 5.5 & 0.9 & 2.1 & 2.4 & 3.3 & 2.6 \\
\hline Differential with euro area average & 0.3 & 1.6 & 2.2 & 0.6 & 0.5 & $\ldots$ & $\ldots$ & $\ldots$ \\
\hline Core inflation (period average) $1 /$ & 1.3 & 2.7 & 3.8 & 1.7 & -0.4 & $\ldots$ & $\ldots$ & $\ldots$ \\
\hline \multicolumn{9}{|l|}{ Employment and wages } \\
\hline Unemployment rate (in percent, ILO definition) & 6.0 & 4.9 & 4.4 & 5.9 & 7.2 & 7.5 & 7.2 & 6.9 \\
\hline Unemployment rate (in percent, registered) & 9.4 & 7.7 & 6.7 & 9.2 & 10.7 & 11.1 & 10.6 & 10.2 \\
\hline Employment (Full employment basis, National accounts) & 1.5 & 3.0 & 2.8 & -1.9 & -2.2 & -0.3 & 0.4 & 0.6 \\
\hline Nominal wages (all sectors) & 4.8 & 5.9 & 8.3 & 3.5 & 3.9 & 3.9 & 4.3 & 3.6 \\
\hline Real wages (all sectors) & 2.3 & 2.2 & 2.5 & 2.6 & 2.0 & 2.3 & 1.9 & 1.9 \\
\hline Unit labor cost (all sectors) & 0.5 & 2.1 & 7.3 & 10.5 & 0.4 & 1.5 & 2.3 & 1.7 \\
\hline \multicolumn{9}{|l|}{ Public finance (percent of GDP) } \\
\hline General government balance 2/ & -0.8 & 0.3 & -0.3 & -5.5 & -5.2 & -4.8 & -4.3 & -3.5 \\
\hline Primary balance & 0.3 & 1.2 & 0.5 & -4.7 & -4.0 & -3.4 & -2.8 & -1.9 \\
\hline Structural balance & -1.9 & -2.4 & -3.6 & -4.5 & -4.0 & -3.7 & -3.4 & -3.0 \\
\hline General government debt & 26.7 & 23.4 & 22.5 & 35.4 & 37.2 & 42.3 & 44.9 & 46.7 \\
\hline \multicolumn{9}{|l|}{ Monetary and financial indicators } \\
\hline Credit to the private sector & 26.5 & 34.1 & 17.2 & 3.2 & 2.0 & $\ldots$ & $\ldots$ & $\ldots$ \\
\hline Lending rates $3 /$ & 5.4 & 5.2 & 6.2 & 5.3 & 4.9 & $\ldots$ & $\ldots$ & $\ldots$ \\
\hline Deposit rates $4 /$ & 3.0 & 3.4 & 4.3 & 2.5 & 1.8 & $\ldots$ & $\ldots$ & $\ldots$ \\
\hline Government bond yield (10-year, average) $5 /$ & 3.9 & 4.5 & 4.7 & 4.4 & 3.8 & $\ldots$ & $\ldots$ & $\ldots$ \\
\hline \multicolumn{9}{|l|}{ Balance of payments (percent of GDP) } \\
\hline Trade balance (goods) & -3.7 & -4.8 & -7.1 & -2.0 & -2.7 & -3.1 & -3.2 & -3.2 \\
\hline Current account balance & -2.5 & -4.8 & -6.7 & -1.5 & -1.2 & -2.0 & -2.1 & -2.1 \\
\hline Gross official reserves (EUR billions) & $5,418.5$ & 723.8 & 687.3 & 749.6 & 730.2 & $\ldots$ & $\ldots$ & $\ldots$ \\
\hline Gross external debt (percent of GDP, end-period) & 77.5 & 100.6 & 105.2 & 113.8 & 113.3 & 114.4 & 112.8 & 112.6 \\
\hline Nominal effective exchange rate $(2000=100)$ & 100.0 & 100.8 & 101.4 & 104.0 & 100.6 & $\ldots$ & $\ldots$ & $\ldots$ \\
\hline Real effective exchange rate $(2000=100, C P I$-based $)$ & 100.1 & 101.8 & 104.0 & 106.8 & 101.9 & $\ldots$ & $\ldots$ & $\ldots$ \\
\hline
\end{tabular}

Sources: Data provided by the Slovenian authorities; and IMF staff calculations and projections.

1/ HICP: Total excl Energy, Food, Alcohol, Tobacco (NSA, 2005=100), period average.

2/ The fiscal deficit could be higher by 0.7 percent of GDP in 2011 if Eurostat classifies the recently approved recapitalization of state banks as state aid for EDP compliance purposes.

3/ Floating or up to one year fixed rate for new loans to non-financial corporations over 1 million euros.

$4 /$ For household time deposits with maturity up to one year.

5/ Eurostat Data. 
Table 2. Slovenia: Consolidated General Government Operations (cash basis), 2007-2013 (Percent of GDP)

\begin{tabular}{|c|c|c|c|c|c|c|c|c|}
\hline & 2006 & 2007 & 2008 & $\begin{array}{l}2009 \\
\text { Outturn }\end{array}$ & $\begin{array}{l}2010 \\
\text { Preliminary } \\
\text { Estimate }\end{array}$ & $\begin{array}{c}2011 \\
\text { Staff } \\
\text { Projections 1/ }\end{array}$ & $\begin{array}{c}2012 \\
\text { Staff } \\
\text { Projections }\end{array}$ & $\begin{array}{c}2013 \\
\text { Staff } \\
\text { Projections }\end{array}$ \\
\hline Total revenues & 41.7 & 40.5 & 41.1 & 40.7 & 41.0 & 40.7 & 40.5 & 40.4 \\
\hline Tax revenues & 37.9 & 36.9 & 37.4 & 36.6 & 35.6 & 36.1 & 36.2 & 36.2 \\
\hline Personal income tax & 5.8 & 5.2 & 5.9 & 5.9 & 5.7 & 5.7 & 5.8 & 5.8 \\
\hline Corporate income tax & 3.0 & 3.2 & 3.4 & 2.0 & 1.2 & 1.4 & 1.4 & 1.4 \\
\hline Social security contributions & 13.6 & 13.3 & 13.7 & 14.6 & 14.5 & 14.7 & 14.8 & 14.8 \\
\hline Taxes on payroll and workforce & 1.5 & 1.2 & 0.7 & 0.1 & 0.1 & 0.1 & 0.1 & 0.1 \\
\hline Domestic taxes on goods and services & 13.1 & 13.0 & 12.9 & 13.2 & 13.3 & 13.3 & 13.3 & 13.3 \\
\hline VAT & 8.7 & 8.4 & 8.4 & 8.0 & 8.2 & 8.2 & 8.2 & 8.2 \\
\hline Excise taxes & 3.1 & 3.3 & 3.3 & 4.0 & 4.0 & 4.0 & 4.0 & 4.0 \\
\hline Other & 1.3 & 1.3 & 1.2 & 1.2 & 1.1 & 1.1 & 1.1 & 1.1 \\
\hline Taxes on international trade & 0.2 & 0.3 & 0.3 & 0.3 & 0.3 & 0.3 & 0.3 & 0.3 \\
\hline Taxes on property & 0.6 & 0.6 & 0.6 & 0.6 & 0.6 & 0.6 & 0.6 & 0.6 \\
\hline Other taxes & 0.0 & 0.0 & 0.0 & 0.0 & 0.0 & 0.0 & 0.0 & 0.0 \\
\hline Nontax revenues & 2.0 & 2.1 & 2.3 & 1.9 & 2.6 & 2.2 & 2.0 & 2.0 \\
\hline Capital revenues and grants & 0.7 & 0.6 & 0.5 & 0.5 & 0.8 & 0.5 & 0.4 & 0.4 \\
\hline Receipts from the EU budget & 1.1 & 1.0 & 1.0 & 1.7 & 2.0 & 2.0 & 1.9 & 1.9 \\
\hline Total expenditures & 42.5 & 40.3 & 41.4 & 46.3 & 46.2 & 45.5 & 44.8 & 43.9 \\
\hline Current expenditures & 38.3 & 36.0 & 36.8 & 41.2 & 41.5 & 41.5 & 40.9 & 39.8 \\
\hline Wages and social security contributions & 10.2 & 9.5 & 9.6 & 11.1 & 10.9 & 10.7 & 10.4 & 10.0 \\
\hline Central and local government & 3.6 & 3.4 & 3.5 & 4.0 & 3.9 & 3.9 & 3.8 & 3.6 \\
\hline Other public institutions & 6.6 & 6.1 & 6.1 & 7.1 & 6.9 & 6.8 & 6.6 & 6.4 \\
\hline Expenditure on goods and services & 6.7 & 6.4 & 6.8 & 7.1 & 7.0 & 6.6 & 6.4 & 6.5 \\
\hline Central and local government & 3.2 & 3.1 & 3.2 & 3.4 & 3.3 & 3.1 & 3.1 & 3.1 \\
\hline Other public institutions & 3.5 & 3.3 & 3.6 & 3.7 & 3.6 & 3.4 & 3.4 & 3.4 \\
\hline Interest payments & 1.2 & 1.0 & 0.9 & 0.9 & 1.4 & 1.4 & 1.6 & 1.7 \\
\hline Transfers to individuals and households & 5.5 & 5.0 & 5.2 & 6.1 & 6.3 & 6.5 & 6.2 & 5.8 \\
\hline Pensions & 10.2 & 9.7 & 9.9 & 10.9 & 11.1 & 11.4 & 11.2 & 11.1 \\
\hline Subsidies & 1.3 & 1.2 & 1.3 & 1.7 & 1.6 & 1.5 & 1.5 & 1.3 \\
\hline Other current transfers & 2.3 & 2.1 & 2.0 & 2.1 & 2.3 & 2.3 & 2.4 & 2.4 \\
\hline Capital expenditures and transfers & 4.2 & 4.2 & 4.6 & 5.1 & 4.7 & 4.0 & 3.9 & 4.1 \\
\hline Acquisition of capital assets & 2.9 & 3.3 & 3.4 & 3.7 & 3.6 & 3.3 & 3.3 & 3.5 \\
\hline Capital transfers & 1.3 & 1.0 & 1.2 & 1.4 & 1.1 & 0.7 & 0.6 & 0.6 \\
\hline Transfers to the EU budget & 0.9 & 1.0 & 1.1 & 1.2 & 1.1 & 1.1 & 1.1 & 1.0 \\
\hline General government balance & -0.8 & 0.3 & -0.3 & -5.5 & -5.2 & -4.8 & -4.3 & -3.5 \\
\hline Primary balance & 0.3 & 1.2 & 0.5 & -4.7 & -4.0 & -3.4 & -2.8 & -1.9 \\
\hline \multicolumn{9}{|l|}{ Memorandum items: } \\
\hline General government balance (ESA 95) & -1.2 & 0.5 & -0.7 & -6.0 & -5.6 & -5.1 & -4.6 & -3.8 \\
\hline Structural budget balance & -1.9 & -2.4 & -3.6 & -4.5 & -4.0 & -3.7 & -3.4 & -3.0 \\
\hline Structural primary balance & -0.8 & -1.5 & -2.8 & -3.6 & -2.7 & -2.3 & -1.9 & -1.4 \\
\hline General government debt & 26.7 & 23.4 & 22.5 & 35.4 & 37.2 & 42.3 & 44.9 & 46.7 \\
\hline Nominal GDP (millions of euro) & 31,050 & 34,568 & 37,305 & 35,384 & 36,061 & 37,037 & 38,944 & 40,859 \\
\hline
\end{tabular}

Sources: Ministry of Finance; and IMF staff calculations.

1/ The fiscal deficit could be higher by 0.7 percent of GDP in 2011 if Eurostat classifies the recapitalization of state banks as state aid. 
Table 3. Slovenia: Balance of Payments, 2006-2013

(Millions of euros, unless otherwise noted)

\begin{tabular}{|c|c|c|c|c|c|c|c|c|}
\hline & \multirow[b]{2}{*}{2006} & \multirow[b]{2}{*}{2007} & \multirow[b]{2}{*}{2008} & \multirow[b]{2}{*}{2009} & \multicolumn{4}{|c|}{ Projections } \\
\hline & & & & & 2010 & 2011 & 2012 & 2013 \\
\hline Current account & -771 & $-1,646$ & $-2,489$ & -526 & -419 & -741 & -817 & -857 \\
\hline Trade balance, goods and services & -158 & -619 & $-1,157$ & 415 & 91 & -86 & -123 & -116 \\
\hline Goods & $-1,151$ & $-1,666$ & $-2,650$ & -699 & -964 & $-1,166$ & $-1,257$ & $-1,305$ \\
\hline Exports f.o.b. & 17,028 & 19,799 & 20,048 & 16,167 & 18,362 & 20,487 & 22,452 & 24,353 \\
\hline Imports f.o.b. & $-18,179$ & $-21,464$ & $-22,699$ & $-16,866$ & $-19,326$ & $-21,653$ & $-23,708$ & $-25,658$ \\
\hline Services & 993 & 1,047 & 1,493 & 1,114 & 1,055 & 1,080 & 1,134 & 1,189 \\
\hline Exports & 3,572 & 4,145 & 5,043 & 4,301 & 4,352 & 4,696 & 4,958 & 5,200 \\
\hline Imports & $-2,580$ & $-3,098$ & $-3,549$ & $-3,187$ & $-3,297$ & $-3,617$ & $-3,824$ & $-4,011$ \\
\hline Income, net & -440 & -789 & $-1,030$ & -782 & -613 & -762 & -807 & -859 \\
\hline Current transfers, net & -173 & -239 & -302 & -159 & 104 & 107 & 113 & 118 \\
\hline Capital account & -132 & -52 & -25 & -9 & 11 & 0 & 0 & 0 \\
\hline Financial account, excl. reserves & -58 & 1,832 & 2,550 & 63 & 322 & 741 & 817 & 857 \\
\hline Direct investment, net & -174 & -210 & 381 & -539 & 516 & 333 & 389 & 409 \\
\hline In Slovenia & 513 & 1,106 & 1,330 & -419 & 630 & 593 & 857 & 981 \\
\hline Abroad & -687 & $-1,317$ & -949 & -121 & -114 & -259 & -467 & -572 \\
\hline Portfolio investment, net & $-1,443$ & $-2,255$ & 572 & 4,624 & 1,838 & 444 & 428 & -327 \\
\hline Financial derivatives & -13 & -21 & 6 & 6 & 0 & 0 & 0 & 0 \\
\hline Other investment, net & 1,571 & 4,313 & 1,551 & $-4,021$ & $-1,942$ & -37 & -1 & 775 \\
\hline Government & -115 & -43 & -29 & -22 & -3 & -37 & -39 & -41 \\
\hline Bank of Slovenia & -1 & -45 & -6 & -1 & 99 & 0 & 0 & 0 \\
\hline Commercial banks & 1,960 & 5,555 & 1,499 & $-3,957$ & $-1,075$ & 30 & 129 & 613 \\
\hline Nonbank private sector & -273 & -281 & -397 & -821 & -916 & -493 & -620 & -519 \\
\hline Loans & 479 & 341 & 576 & 45 & -242 & 78 & 81 & 284 \\
\hline Household currency and deposits & -805 & -655 & -685 & -947 & -840 & -467 & -545 & -631 \\
\hline Trade credits & 36 & 100 & -215 & -42 & 138 & -37 & -78 & -82 \\
\hline Other & 17 & -66 & -73 & 123 & 27 & -67 & -78 & -90 \\
\hline Net errors and omissions & -321 & -274 & -56 & 305 & 67 & 0 & 0 & 0 \\
\hline Overall balance & $-1,281$ & -140 & -21 & -167 & -19 & 0 & 0 & 0 \\
\hline Change in official reserves (-: increase) & 1,281 & 140 & 21 & 167 & 19 & 0 & 0 & 0 \\
\hline \multicolumn{9}{|l|}{ Memorandum items: } \\
\hline Current account balance (percent of GDP) & -2.5 & -4.8 & -6.7 & -1.5 & -1.2 & -2.0 & -2.1 & -2.1 \\
\hline Export of goods (percent change in value) & 16.6 & 16.3 & 1.3 & -19.4 & 13.6 & 11.6 & 9.6 & 8.5 \\
\hline Import of goods (percent change in value) & 16.4 & 18.1 & 5.7 & -25.6 & 14.6 & 11.8 & 9.5 & 8.2 \\
\hline Terms of trade (percent change) & -0.4 & 0.6 & -1.8 & 4.7 & -3.2 & -0.2 & 0.0 & 0.0 \\
\hline Gross external debt & 24,067 & 34,783 & 39,234 & 40,276 & 40,851 & 42,366 & 43,924 & 46,024 \\
\hline (percent of GDP) & 77.5 & 100.6 & 105.2 & 113.8 & 113.3 & 114.4 & 112.8 & 112.6 \\
\hline Net external debt (liabilities - assets) $1 /$ & 3394.0 & 6352.0 & 9976.0 & 10682.0 & 11332.0 & 11513.5 & 11747.8 & 11762.8 \\
\hline (percent of GDP) & 10.9 & 18.4 & 26.7 & 30.2 & 31.4 & 31.1 & 30.2 & 28.8 \\
\hline
\end{tabular}

1/ A negative number indicates net creditor position. 
Table 4. Slovenia: Macroeconomic Framework, 2006-2015

\begin{tabular}{|c|c|c|c|c|c|c|c|c|c|c|}
\hline & \multirow[b]{2}{*}{2006} & \multirow[b]{2}{*}{2007} & \multirow[b]{2}{*}{2008} & \multirow[b]{2}{*}{2009} & \multicolumn{6}{|c|}{ Projections } \\
\hline & & & & & 2010 & 2011 & 2012 & 2013 & 2014 & 2015 \\
\hline Real GDP (percent change) & 5.9 & 6.9 & 3.7 & -8.1 & 1.2 & 2.0 & 2.4 & 2.5 & 2.3 & 2.0 \\
\hline \multicolumn{11}{|l|}{ Contribution } \\
\hline Domestic demand & 5.8 & 9.0 & 4.2 & -10.5 & 0.4 & 1.0 & 2.2 & 2.6 & 2.4 & 2.1 \\
\hline Private consumption & 1.6 & 3.6 & 1.5 & -0.4 & 0.3 & 0.7 & 1.2 & 1.3 & 1.2 & 1.0 \\
\hline Government consumption & 0.7 & 0.1 & 1.1 & 0.5 & 0.2 & -0.5 & -0.2 & 0.1 & 0.1 & 0.1 \\
\hline Gross investment & 3.4 & 5.4 & 1.6 & -10.6 & 0.0 & 0.8 & 1.1 & 1.1 & 1.1 & 1.0 \\
\hline Net foreign demand & 0.1 & -2.2 & -0.5 & 2.2 & 0.7 & 1.0 & 0.2 & -0.1 & -0.1 & -0.1 \\
\hline Exports of goods and services & 8.2 & 9.6 & 2.5 & -13.1 & 5.1 & 4.8 & 4.2 & 4.2 & 4.2 & 4.4 \\
\hline Imports of goods and services & -8.1 & -11.8 & -3.0 & 15.3 & -4.5 & -3.8 & -4.0 & -4.2 & -4.3 & -4.4 \\
\hline Output gap (in percent of potential) & 2.5 & 6.8 & 8.3 & -2.4 & -3.0 & -2.6 & -2.0 & -1.1 & -0.5 & -0.1 \\
\hline \multicolumn{11}{|l|}{ Growth rates } \\
\hline Domestic demand & 5.7 & 8.9 & 4.1 & -10.1 & 0.4 & 1.0 & 2.2 & 2.6 & 2.5 & 2.1 \\
\hline Consumption & 3.2 & 5.1 & 3.7 & 0.2 & 0.6 & 0.2 & 1.4 & 1.9 & 1.8 & 1.5 \\
\hline Government & 4.0 & 0.7 & 6.2 & 3.0 & 0.8 & -2.4 & -1.0 & 0.7 & 0.4 & 0.5 \\
\hline Non-government & 2.9 & 6.7 & 2.9 & -0.8 & 0.5 & 1.2 & 2.2 & 2.3 & 2.2 & 1.8 \\
\hline Gross capital formation & 12.2 & 18.2 & 4.9 & -32.0 & 0.0 & 3.5 & 4.5 & 4.6 & 4.4 & 3.9 \\
\hline Fixed investment & 10.1 & 12.8 & 8.5 & -21.6 & -6.7 & 1.0 & 4.7 & 4.8 & 4.6 & 4.0 \\
\hline Change in stocks (contribution to GDP growth & 0.8 & 1.9 & -0.8 & -4.1 & 1.7 & 0.6 & 0.0 & 0.0 & 0.0 & 0.0 \\
\hline Exports of goods and services & 12.5 & 13.7 & 3.3 & -17.7 & 7.8 & 6.8 & 5.7 & 5.5 & 5.4 & 5.4 \\
\hline Imports of goods and services & 12.2 & 16.7 & 3.8 & -19.7 & 6.6 & 5.3 & 5.4 & 5.6 & 5.5 & 5.5 \\
\hline \multicolumn{11}{|l|}{ Savings and investment (percent of GDP) } \\
\hline National saving & 26.5 & 26.9 & 25.3 & 21.5 & 22.0 & 22.1 & 22.5 & 23.0 & 23.3 & 23.6 \\
\hline Government & 3.4 & 4.5 & 4.3 & -0.5 & -0.5 & -0.8 & -0.4 & 0.7 & 1.1 & 1.2 \\
\hline Non-government & 23.1 & 22.4 & 21.0 & 22.0 & 22.5 & 22.9 & 22.9 & 22.3 & 22.3 & 22.4 \\
\hline Gross capital formation & 28.9 & 31.7 & 31.9 & 23.0 & 23.1 & 24.1 & 24.6 & 25.1 & 25.5 & 26.0 \\
\hline Government 1/ & 2.9 & 3.3 & 3.4 & 3.7 & 3.6 & 3.3 & 3.3 & 3.5 & 3.5 & 3.5 \\
\hline Non-government & 26.0 & 28.4 & 28.6 & 19.4 & 19.5 & 20.8 & 21.4 & 21.6 & 22.0 & 22.5 \\
\hline Foreign saving & -2.5 & -4.8 & -6.7 & -1.5 & -1.2 & -2.0 & -2.1 & -2.1 & -2.2 & -2.4 \\
\hline \multicolumn{11}{|l|}{ Prices } \\
\hline Consumer price inflation & 2.5 & 3.6 & 5.7 & 0.9 & 1.8 & 2.2 & 3.1 & 2.3 & 2.3 & 2.4 \\
\hline GDP deflator & 2.0 & 4.2 & 4.0 & 3.2 & 0.7 & 0.7 & 2.7 & 2.4 & 2.5 & 2.3 \\
\hline Employment (percent change) & 1.5 & 3.0 & 2.8 & -1.9 & -2.2 & -0.3 & 0.4 & 0.6 & 0.6 & 0.5 \\
\hline Unemployment rate (ILO, percent) & 6.0 & 4.9 & 4.4 & 5.9 & 7.2 & 7.5 & 7.2 & 6.9 & 6.5 & 5.9 \\
\hline Real wages (percent change) & 2.3 & 2.2 & 2.5 & 2.6 & 2.0 & 2.3 & 1.9 & 1.9 & 1.7 & 1.5 \\
\hline \multicolumn{11}{|l|}{ Government budget (percent of GDP) } \\
\hline Revenue & 41.7 & 40.5 & 41.1 & 40.7 & 41.0 & 40.7 & 40.5 & 40.4 & 40.4 & 40.4 \\
\hline Expenditure & 42.5 & 40.3 & 41.4 & 46.3 & 46.2 & 45.5 & 44.8 & 43.9 & 43.4 & 43.3 \\
\hline General government balance & -0.8 & 0.3 & -0.3 & -5.5 & -5.2 & -4.8 & -4.3 & -3.5 & -3.1 & -2.9 \\
\hline Structural government balance & -1.9 & -2.4 & -3.6 & -4.5 & -4.0 & -3.7 & -3.4 & -3.0 & -2.9 & -2.9 \\
\hline General government debt & & 23.4 & 22.5 & 35.4 & 37.2 & 42.3 & 44.9 & 46.7 & 48.0 & 49.3 \\
\hline \multicolumn{11}{|l|}{ Merchandise trade (percent change) } \\
\hline Export volume & 13.4 & 13.9 & 0.6 & -18.1 & 10.2 & 7.6 & 6.3 & 6.0 & 5.8 & 5.8 \\
\hline Import volume & 12.7 & 16.2 & 3.1 & -20.9 & 7.6 & 4.9 & 6.0 & 6.1 & 6.0 & 5.9 \\
\hline Export value & 16.6 & 16.3 & 1.3 & -19.4 & 13.6 & 11.6 & 9.6 & 8.5 & 8.3 & 8.4 \\
\hline Import value & 16.3 & 18.1 & 5.7 & -25.6 & 14.6 & 11.8 & 9.5 & 8.2 & 7.9 & 8.5 \\
\hline \multicolumn{11}{|l|}{ External balances (in billions of euros) } \\
\hline Trade balance & -1.2 & -1.7 & -2.7 & -0.7 & -1.0 & -1.2 & -1.3 & -1.3 & -1.3 & -1.5 \\
\hline In percent of GDP & -3.7 & -4.8 & -7.1 & -2.0 & -2.7 & -3.1 & -3.2 & -3.2 & -3.1 & -3.3 \\
\hline Exports of goods & 17.0 & 19.8 & 20.0 & 16.2 & 18.4 & 20.5 & 22.5 & 24.4 & 26.4 & 28.6 \\
\hline Imports of goods & 18.2 & 21.5 & 22.7 & 16.9 & 19.3 & 21.7 & 23.7 & 25.7 & 27.7 & 30.0 \\
\hline Current account & -0.8 & -1.6 & -2.5 & -0.5 & -0.4 & -0.7 & -0.8 & -0.9 & -0.9 & -1.1 \\
\hline In percent of GDP & -2.5 & -4.8 & -6.7 & -1.5 & -1.2 & -2.0 & -2.1 & -2.1 & -2.2 & -2.4 \\
\hline
\end{tabular}

Sources: Data provided by the authorities; and IMF staff projections.

1/ Government capital transfers are not included in government investment. 
Table 5. Slovenia: External Debt Sustainability Framework, 2006-2016

(In percent of GDP, unless otherwise indicated)

\begin{tabular}{|c|c|c|c|c|c|c|c|c|c|c|c|c|}
\hline & \multicolumn{5}{|c|}{ Actual } & \multicolumn{7}{|c|}{ Projections } \\
\hline & 2006 & 2007 & 2008 & 2009 & 2010 & 2011 & 2012 & 2013 & 2014 & 2015 & 2016 & \multirow{2}{*}{$\begin{array}{c}\text { Debt-stabilizing } \\
\text { non-interest } \\
\text { current account } 6\end{array}$} \\
\hline & & & & & & & & & & & & \\
\hline Baseline: External debt & 81.6 & 107.0 & 97.3 & 119.3 & 112.9 & 118.3 & 116.5 & 116.4 & 116.4 & 117.2 & 118.3 & -4.1 \\
\hline Change in external debt & 13.7 & 25.5 & -9.7 & 22.0 & -6.5 & 5.4 & -1.7 & -0.2 & 0.0 & 0.8 & 1.1 & \\
\hline Identified external debt-creating flows $(4+8+9)$ & -3.0 & -9.6 & -1.5 & 8.2 & -2.9 & -1.2 & -1.6 & -1.7 & -1.4 & -0.9 & -0.5 & \\
\hline Current account deficit, excluding interest payments & 0.8 & 2.3 & 3.5 & -0.1 & 0.2 & 0.4 & 0.5 & 0.5 & 0.6 & 0.8 & 1.0 & \\
\hline Deficit in balance of goods and services & 0.5 & 1.8 & 3.1 & -1.2 & -0.3 & 0.2 & 0.3 & 0.3 & 0.2 & 0.4 & 0.5 & \\
\hline Exports & 66.3 & 69.3 & 67.3 & 57.8 & 63.0 & 70.3 & 73.0 & 75.0 & 77.0 & 79.6 & 82.4 & \\
\hline Imports & 66.9 & 71.1 & 70.4 & 56.7 & 62.7 & 70.6 & 73.3 & 75.3 & 77.2 & 80.0 & 82.9 & \\
\hline Automatic debt dynamics $1 /$ & -3.9 & -11.9 & -4.4 & 6.8 & -1.3 & -0.6 & -1.0 & -1.1 & -0.9 & -0.6 & -0.4 & \\
\hline Contribution from nominal interest rate & 1.7 & 2.5 & 3.2 & 1.6 & 1.0 & 1.7 & 1.6 & 1.7 & 1.7 & 1.7 & 1.8 & \\
\hline Contribution from real GDP growth & -3.6 & -4.6 & -3.5 & 8.8 & -1.5 & -2.2 & -2.7 & -2.8 & -2.6 & -2.3 & -2.2 & \\
\hline Contribution from price and exchange rate changes $2 /$ & -1.9 & -9.7 & -4.2 & -3.6 & -0.8 & $\ldots$ & $\ldots$ & $\ldots$ & $\ldots$ & $\ldots$ & $\ldots$ & \\
\hline Residual, incl. change in gross foreign assets (2-3) $3 /$ & 16.7 & 35.0 & -8.2 & 13.8 & -3.5 & 6.6 & -0.1 & 1.5 & 1.4 & 1.7 & 1.6 & \\
\hline External debt-to-exports ratio (in percent) & 122.9 & 154.5 & 144.7 & 206.3 & 179.2 & 168.2 & 159.7 & 155.1 & 151.1 & 147.2 & 143.5 & \\
\hline Gross external financing need (in billions of US dollars) $4 /$ & 10.2 & 14.1 & 26.0 & 23.8 & 22.4 & 20.3 & 22.9 & 23.5 & 24.3 & 25.2 & 26.2 & \\
\hline in percent of GDP & 26.1 & 29.7 & 47.4 & 48.4 & 46.9 & 41.5 & 44.8 & 44.1 & 43.9 & 44.0 & 44.2 & \\
\hline \multicolumn{13}{|l|}{ Key Macroeconomic Assumptions Underlying Baseline } \\
\hline Nominal GDP (US dollars) & 39.0 & 47.4 & 54.9 & 49.3 & 47.8 & 49.0 & 51.2 & 53.3 & 55.4 & 57.3 & 59.3 & \\
\hline Real GDP growth (in percent) & 5.9 & 6.9 & 3.7 & -8.1 & 1.2 & 2.0 & 2.4 & 2.5 & 2.3 & 2.0 & 1.9 & \\
\hline Exchange rate appreciation (US dollar value of local currency, char & 0.8 & 9.2 & 7.4 & -5.4 & -4.7 & -0.3 & -0.7 & -0.8 & -0.8 & -0.8 & -0.8 & \\
\hline GDP deflator (change in domestic currency) & 2.0 & 4.2 & 4.0 & 3.2 & 0.7 & 0.7 & 2.7 & 2.4 & 2.5 & 2.3 & 2.3 & \\
\hline GDP deflator in US dollars (change in percent) & 2.9 & 13.7 & 11.7 & -2.3 & -4.1 & 0.4 & 2.0 & 1.6 & 1.6 & 1.4 & 1.5 & \\
\hline Nominal external interest rate (in percent) & 2.7 & 3.7 & 3.5 & 1.4 & 0.8 & 1.5 & 1.4 & 1.5 & 1.5 & 1.5 & 1.5 & \\
\hline Growth of exports (US dollar terms, in percent) & 16.6 & 26.9 & 12.5 & -22.8 & 5.7 & 14.4 & 8.3 & 7.0 & 6.8 & 7.0 & 7.0 & \\
\hline Growth of imports (US dollar terms, in percent) & 16.8 & 29.2 & 14.7 & -27.7 & 7.5 & 15.2 & 8.4 & 6.9 & 6.7 & 7.2 & 7.2 & \\
\hline Current account balance, excluding interest payments & -0.8 & -2.3 & -3.5 & 0.1 & -0.2 & -0.4 & -0.5 & -0.5 & -0.6 & -0.8 & -1.0 & \\
\hline Net non-debt creating capital inflows & -0.1 & 0.0 & 0.5 & -1.5 & 1.8 & 1.0 & 1.1 & 1.1 & 1.1 & 1.1 & 1.1 & \\
\hline
\end{tabular}

$1 /$ Derived as $[r-g-\rho(1+g)+\alpha \alpha(1+r)](1+g+\rho+g \rho)$ times previous period debt stock, with $r=$ nominal effective interest rate on external debt; $\rho=$ change in domestic GDP deflator in US dollar terms, $g=$ real GDP growth rate,

$\varepsilon=$ nominal appreciation (increase in dollar value of domestic currency), and $\alpha=$ share of domestic-currency denominated debt in total external debt.

$2 /$ The contribution from price and exchange rate changes is defined as $[-\rho(1+g)+\varepsilon \alpha(1+r)] /(1+g+\rho+g \rho)$ times previous period debt stock. $\rho$ increases with an appreciating domestic currency $(\varepsilon>0)$ and rising inflation $($ based on GDP deflator) $3 /$ For projection, line includes the impact of price and exchange rate changes.

4/ Defined as current account deficit, plus amortization on medium- and long-term debt, plus short-term debt at end of previous period.

$5 /$ The key variables include real GDP growth; nominal interest rate; dollar deflator growth; and both non-interest current account and non-debt inflows in percent of GDP.

6/ Long-run, constant balance that stabilizes the debt ratio assuming that key variables (real GDP growth, nominal interest rate, dollar deflator growth, and non-debt inflows in percent of GDP) remain at their levels

of the last projection year. 
Table 6. Slovenia: Public Sector Debt Sustainability Framework, 2006-2016

(In percent of GDP, unless otherwise indicated)

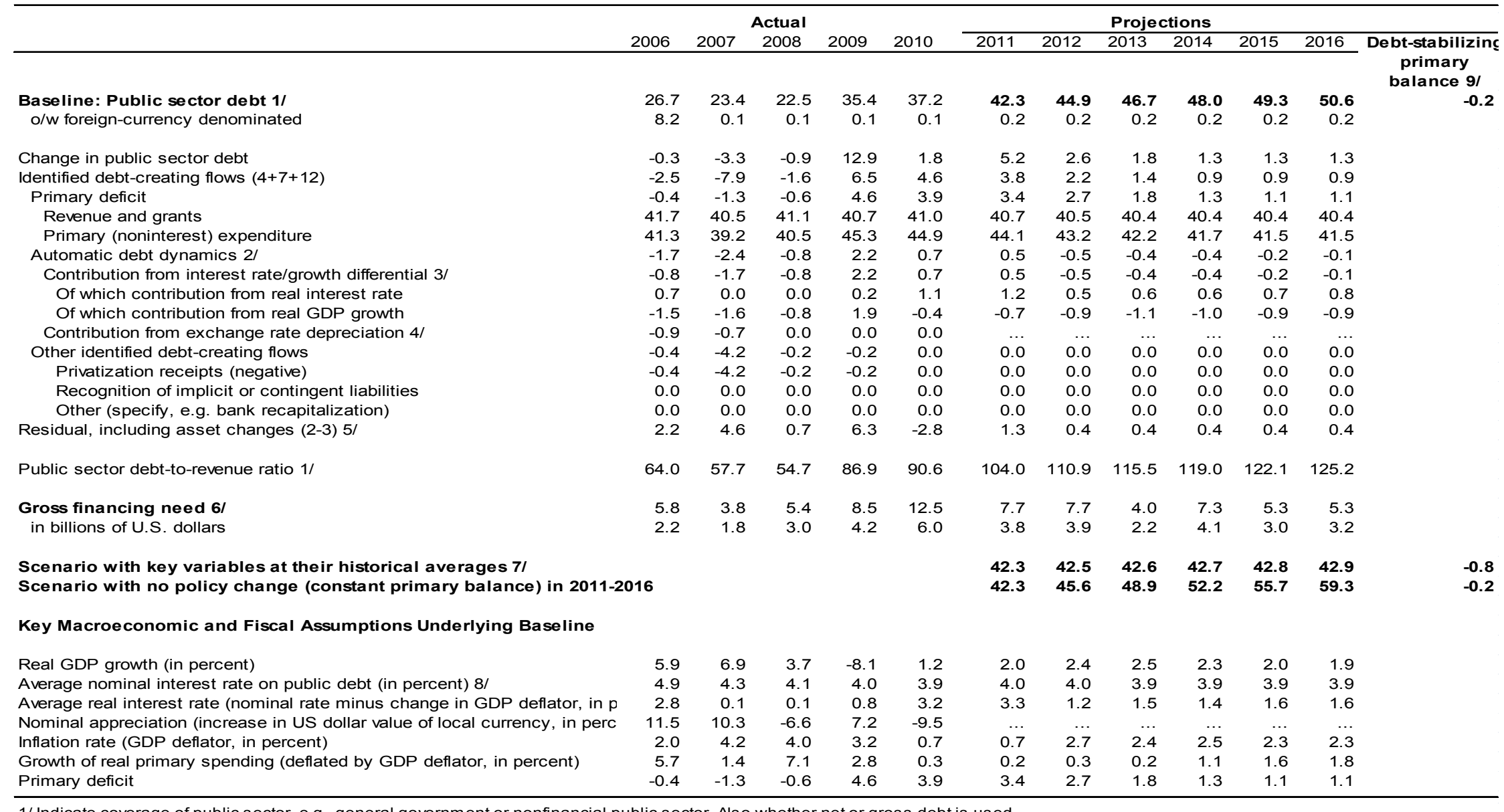

$1 /$ Indicate coverage of public sector, e.g., general government or nonfinancial public sector. Also whether net or gross debt is used.

$2 /$ Derived as $[(r-\pi(1+g)-g+\alpha \varepsilon(1+r)] /(1+g+\pi+g \pi))$ times previous period debt ratio, with $r=$ interest rate; $\pi=$ growth rate of GDP deflator; $g=$ real GDP growth rate; $\alpha=$ share of foreign-currency denominated debt; and $\varepsilon=$ nominal exchange rate depreciation (measured by increase in local currency value of U.S. dollar).

$3 /$ The real interest rate contribution is derived from the denominator in footnote $2 /$ as $r-\pi(1+g)$ and the real growth contribution as $-g$.

$4 /$ The exchange rate contribution is derived from the numerator in footnote $2 /$ as $\alpha \varepsilon(1+r)$.

$5 /$ For projections, this line includes exchange rate changes.

6/ Defined as public sector deficit, plus amortization of medium and long-term public sector debt, plus short-term debt at end of previous period.

7/ The key variables include real GDP growth; real interest rate; and primary balance in percent of GDP.

8/ Derived as nominal interest expenditure divided by previous period debt stock.

9/ Assumes that key variables (real GDP growth, real interest rate, and other identified debt-creating flows) remain at the level of the last projection year. 
Table 7. Banking Sector Soundness Indicators 1/

(Percent, end of period)

\begin{tabular}{|c|c|c|c|c|c|c|}
\hline & 2005 & 2006 & 2007 & 2008 & 2009 & 201021 \\
\hline \multicolumn{7}{|l|}{ Capital adequacy } \\
\hline Regulatory capital to risk-weighted assets & 10.5 & 11.1 & 11.2 & 11.7 & 11.6 & 11.5 \\
\hline Regulatory Tier 1 capital to risk-weighted assets & 8.9 & 9.4 & 8.9 & 9.2 & 9.3 & 9.3 \\
\hline Capital (net worth) to assets & 8.5 & 8.4 & 8.4 & 8.4 & 8.3 & 8.2 \\
\hline \multicolumn{7}{|l|}{ Asset quality } \\
\hline Non-performing loans to total assets & 2.9 & 2.5 & 1.8 & 1.8 & 2.3 & 3.6 \\
\hline Specific provisions to non-performing loans & 80.6 & 84.3 & 86.4 & 79.3 & 75.9 & 72.6 \\
\hline Large exposures to capital & 226.2 & 222.9 & 217.4 & 127.5 & 112.6 & 99.2 \\
\hline \multicolumn{7}{|l|}{ Earnings and profitability } \\
\hline Net interest margin on average interest bearing assets & 2.6 & 2.4 & 2.3 & 2.2 & 2.0 & 2.1 \\
\hline Operating expenses to average assets & 2.5 & 2.2 & 2.0 & 1.7 & 1.5 & 1.5 \\
\hline Return on average assets (before tax) & 1.0 & 1.3 & 1.4 & 0.7 & 0.3 & -0.2 \\
\hline Return on average equity (before tax) & 13.8 & 15.1 & 16.3 & 8.1 & 3.9 & -2.3 \\
\hline \multicolumn{7}{|l|}{ Liquidity } \\
\hline Average liquid assets to average total assets & 4.8 & 4.5 & 3.6 & 14.0 & 13.9 & 14.3 \\
\hline Average liquid assets to average short-term deposits & 9.51 & 9.72 & 8.4 & 34.6 & 36.1 & 42.9 \\
\hline \multicolumn{7}{|l|}{ Foreign exchange risk } \\
\hline Foreign currency-denominated loans to total loans & 48.7 & 55.9 & 6.0 & 6.1 & 5.1 & 4.7 \\
\hline Foreign currency-denominated liabilities to total liabilities & 49.4 & 53.3 & 4.9 & 4.8 & 3.4 & 3.6 \\
\hline Net open position in foreign exchange to capital & 58.8 & 7.7 & $\ldots$ & 0.2 & 0.9 & $\ldots$ \\
\hline \multicolumn{7}{|l|}{ Market risk } \\
\hline $\begin{array}{l}\text { Assets with maturity of more than } 1 \text { year } \\
\text { (percent of total loans to non-bank sector) }\end{array}$ & 32.3 & 33.4 & 35.1 & 37.6 & 31.7 & 27.1 \\
\hline Liabilities with maturity of less than 3 months & & & & & & \\
\hline (percent of total liabilities to non-bank sector) & 66.9 & 68.2 & 66.3 & 57.1 & 46.6 & 47.0 \\
\hline \multicolumn{7}{|l|}{ Memorandum item: } \\
\hline \multicolumn{7}{|l|}{ Ownership of banking sector (percent of equity capital) } \\
\hline Nonresidents & 34.9 & 37.7 & 37.7 & 38.2 & 36.6 & 37.1 \\
\hline Central government & 18.2 & 17.4 & 15.1 & 17.7 & 20.5 & 20.1 \\
\hline Other domestic entities & 46.9 & 44.6 & 47.2 & 44.1 & 43.0 & 42.9 \\
\hline
\end{tabular}

Source: Bank of Slovenia

1/ Indicators after 2007 are subject to change. Missing observations are expected to be obtained from the authorities during the mission.

2/ Latest month for which information was available 
Table 8. Slovenia: Vulnerability Indicators, 2005-2010

(Percent of GDP, unless otherwise indicated)

\begin{tabular}{|c|c|c|c|c|c|c|}
\hline & 2005 & 2006 & 2007 & 2008 & 2009 & $20103 /$ \\
\hline \multicolumn{7}{|l|}{ Financial Indicators (end of period) } \\
\hline General government debt & 27.0 & 26.7 & 23.4 & 22.5 & 35.4 & 37.2 \\
\hline Domestic Credit to Non Financial Institutions & 68.0 & 76.5 & 86.0 & 91.6 & 103.6 & 103.6 \\
\hline Private sector credit (percent change) $1 /$ & 23.4 & 23.8 & 32.5 & 17.2 & 2.8 & 3.2 \\
\hline Foreign exchange deposits (in billions of euros) $2 /$ & 5.3 & 5.7 & 0.5 & 0.4 & 0.4 & 0.4 \\
\hline Banks' nonperforming loans (percent of total gross loans) & 2.5 & 2.5 & 1.8 & 1.8 & 2.3 & 3.6 \\
\hline Capital adequacy ratio & 10.5 & 11.0 & 11.2 & 11.7 & 11.6 & 11.5 \\
\hline \multicolumn{7}{|l|}{ Financial Market Indicators (end of period) } \\
\hline Stock market index & 4,630 & 6,383 & 11,370 & 3,696 & 4,079 & 3281.4 \\
\hline Stock market index (Blue Chip Index) & 941 & 1,473 & 2,519 & 854 & 983 & 807.9 \\
\hline Stock market capitalization & 23.3 & 37.1 & 57.0 & 22.7 & 23.9 & 19.4 \\
\hline Sovereign Credit Rating (S\&P) & AA- & $\mathrm{AA}$ & $\mathrm{AA}$ & $\mathrm{AA}$ & AA & $\mathrm{AA}$ \\
\hline \multicolumn{7}{|l|}{ External Indicators } \\
\hline Exports of goods and services (percent change, value in euros) & 13.3 & 15.7 & 16.2 & 4.8 & -18.4 & 11.0 \\
\hline Imports of goods and services (percent change, value in euros) & 11.7 & 15.9 & 18.3 & 6.9 & -23.6 & 12.8 \\
\hline Current account balance & -1.7 & -2.5 & -4.8 & -6.7 & -1.5 & -1.2 \\
\hline Net foreign assets of commercial banks (in billions of euros) 2/ & -5.1 & -6.1 & -6.5 & -8.6 & -7.0 & -7.8 \\
\hline Short-term foreign assets of commercial banks (in billions of euros) & 1.8 & 2.0 & 4.2 & 3.5 & 4.4 & 3.8 \\
\hline Short-term foreign liabilities of commercial banks (in billions of euros) & 1.5 & 1.6 & 3.1 & 3.6 & 2.3 & 2.3 \\
\hline Foreign currency exposure of commercial banks (in billions of euros) $2 /$ & -13.9 & -16.8 & -16.7 & -18.3 & -17.1 & -17.0 \\
\hline Gross official reserves (in billions of euros) & 6.9 & 5.4 & 0.7 & 0.7 & 0.7 & 0.7 \\
\hline Gross official reserves (in months of imports of goods and services) & 4.6 & 3.1 & 0.4 & 0.3 & 0.4 & 0.4 \\
\hline Net international reserves (in billions of euros) & 5.3 & 4.9 & 0.7 & 0.6 & 0.7 & 0.7 \\
\hline Total external debt & 71.3 & 77.5 & 100.6 & 105.2 & 113.8 & 113.3 \\
\hline Of which: Public and publicly guaranteed & 13.2 & 14.0 & 23.4 & 24.5 & 39.5 & 47.4 \\
\hline Total external debt (in percent of exports of goods and services) & 115.1 & 116.8 & 145.3 & 156.4 & 196.8 & 179.9 \\
\hline Total external debt service payments (in percent of exports of goods and services) & 15.1 & 17.8 & 19.2 & 23.7 & 29.6 & 29.1 \\
\hline External interest payment (in percent of exports of goods and services) & 2.7 & 3.1 & 4.2 & 5.4 & 3.9 & 3.5 \\
\hline External amortization payments (in percent of exports of goods and services) & 12.5 & 14.7 & 15.0 & 18.2 & 25.7 & 25.6 \\
\hline REER (CPI-based, period-average basis, an increase indicates appreciation) & -0.9 & 0.1 & 2.1 & 2.5 & 1.2 & 0.5 \\
\hline
\end{tabular}

Sources: Data provided by the Slovene authorities; Bloomberg; and IMF staff calculations.

1/ Credit including loans and other claims. Series presents a structural break in 2007 due to entry in the Euro zone.

2/ Series present a structural break in 2007 due to the entry in the Euro Zone.

3/ Latest observations available. 


\section{INTERNATIONAL MONETARY FUND \\ REPUBLIC OF SLOVENIA}

\section{Staff Report for the 2011 Article IV Consultation-Informational Annex}

Prepared by the European Department

May 4, 2011

Contents

Pages

Appendices

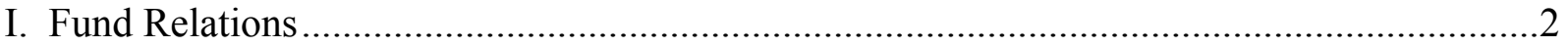

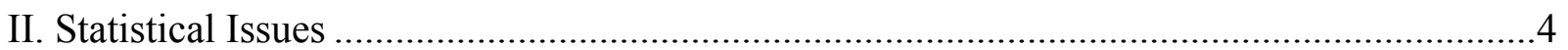




\section{APPENDIX I: REPUBLIC OF SLOVENIA: FUND RELATIONS}

(As of March 31, 2011)

I. Membership Status: Joined: 12/14/1992; Article VIII status as from

September 1, 2005.

$\begin{array}{lrr}\text { II. General Resources Account } & \text { SDR Million } & \text { \% Quota } \\ \text { Quota } & 275.00 & 100.00 \\ \text { Fund holdings of currency } & 198.37 & 72.14 \\ \text { Reserve Tranche position } & 76.65 & 27.86 \\ \text { Lending to the Fund } & 24.30 & \end{array}$

III. SDR Department

Net cumulative allocation $\quad 215.88 \quad 100.00$

$\begin{array}{lll}\text { Holdings } & 187.39 & 86.80\end{array}$

IV. Projected Payments to Fund ${ }^{4}$

(SDR Million; based on existing use of resources and present holdings of SDRs):

Forthcoming

\section{$\begin{array}{lllll}2011 & 2012 & 2013 & 2014 & 2015\end{array}$}

$\begin{array}{llllll}\text { Charges/Interest } & 0.09 & 0.14 & 0.14 & 0.14 & 0.14 \\ \text { Total } & 0.09 & 0.14 & 0.14 & 0.14 & 0.14\end{array}$

\section{Exchange Rate Arrangement}

Slovenia adopted the euro on January 1, 2007. Slovenia has accepted the obligations of Article VIII. Slovenia maintains an exchange system that is free of restrictions on the making of payments and transfers for current international transactions, with the exception of exchange restrictions maintained for security reasons, which have been notified to the Fund pursuant to Decision No. 144-(52/51).

\section{2011 Article IV Consultation}

Slovenia is on the 24-month Article IV consultation cycle. The 2011 mission visited Ljubljana during March 9-21, 2011 and held discussions with the Minister of Finance, the Governor of the Bank of Slovenia, and other key economic ministers, government officials and representatives of the Parliament, financial sector, labor, business and media. Mr. Kavčič

\footnotetext{
${ }^{4}$ When a member has overdue financial obligations outstanding for more than three months, the amount of such arrears will be shown in this section.
} 
(Advisor to the Executive Director) attended the meetings. Mr. Prader (Alternate Executive Director) attended the concluding meeting.

The mission comprised: Mr. Spilimbergo (Head), Ms. Mahieu, Mr. Simone (all EUR), and Mr. Blotevogel (MCD).

The mission held a press conference on the concluding statement. The authorities have agreed to the publication of the staff report.

\section{FSAP Participation and ROSCs}

An FSAP mission took place during November 6-20, 2000. A FSSA report (SM/01/129) was prepared on April 24, 2001 and published on September 18, 2001 (Country Report No. 01/161). An FSAP Update mission visited Ljubljana during November 10-21, 2003. An FSSA report (SM/04/152) was issued on April 26, 2004.

The fiscal transparency module of the fiscal ROSC was published in June 2002.

\section{Technical Assistance}

\begin{tabular}{lll}
\multicolumn{1}{c}{ Date } & Dept. & Subject/Identified Need \\
August 2001 & FAD & VAT. \\
November 2001 & FAD & Direct Tax Reform. \\
November 2003 & FAD & Expenditure Rationalization. \\
April-May 2004 & FAD & Performance Information to Support Better Budgeting. \\
November 2004 & STA & Recording Transactions in International Trade in Services \\
April 2006 & STA & Government Finance Statistics \\
December 2009 & MCM & Financial Supervisory Architecture
\end{tabular}




\section{APPENDIX II: REPUbLIC OF SLOVENIA: STATISTICAL ISSUES}

1. Data provision is adequate for surveillance purposes.

2. Special Data Dissemination Standard: Slovenia has subscribed to the Special Data Dissemination Standard (SDDS), meets SDDS specifications, and its metadata are posted on the Fund's Dissemination Standards Bulletin Board on the Internet. http://dsbb.imf.org/Applications/web/sddscountrycategorylist/?strcode=SVN

3. Real Sector Statistics: The Statistical Office of the Republic of Slovenia (SORS) follows the European System of Accounts 1995 (ESA95). Quarterly GDP estimates by industry and expenditure categories are compiled in both current and constant prices, and are published within 80 days after the reference quarter. In September 2005, the SORS changed the base year for compiling constant prices GDP from 2000 to the previous year's prices and started using the chain-link index methodology.

4. The SORS compiles the Harmonized Index of Consumer Prices (HICP) for monitoring compliance with the Maastricht inflation criterion. However, price collection is restricted to four cities and their surrounding rural areas. The weights are based on the threeyear average of expenditure data for consumer goods from continuous Household Budget Surveys for 2002, 2003, and 2004. It also compiles a retail price index (RPI), which differs from the consumer price index in weights only.

5. Government Finance Statistics: Slovenian fiscal statistics are timely and of a high quality. The ministry of finance publishes a comprehensive monthly Bulletin of Government Finance, which presents monthly data on the operations of the "state budget" (Budgetary Central Government), local governments, social security (Pension and Health funds), and the consolidated general government. The coverage of general government excludes the operations of extra-budgetary funds and own revenues of general government agencies (zavods). However, these operations are small in size. Monthly fiscal indicators are reported for publication in IFS on a timely basis and annual statistics covering general government operations, including the operations of the extra-budgetary funds are reported for publication in the Government Finance Statistic Yearbook (GFS Yearbook).

6. The data published in the Bulletin of Government Finance are on a cash basis and broadly use the analytical framework and classification system of the IMF's 1986 government finance statistics methodology. The data reported for publication in the GFS Yearbook are also on a cash basis but are recast in the analytical framework and classifications of the Manual on Government Finance Statistics 2001(GFSM 2001).

7. The Slovenian authorities adopted the GFSM 2001 methodology, which is used as a building block for the compilation of the ESA 95-based data jointly by the Ministry of Finance and the SORS for reporting to the European Commission. To assist the Ministry of Finance resolve several classification issues and develop a migration path, a STA technical assistance mission visited Ljubljana in April 2006. The introduction in 2008 of a new chart of 
accounts for all public entities based on accrual principles greatly facilitated the adoption of the new methodology.

8. Money and Banking Statistics: Monetary statistics are timely and of good quality.

9. Balance of Payments Statistics: Balance of payments data are comprehensive and of high quality. The data have been published in the Balance of Payments Statistics Yearbook since 1993 (with estimates of the international investment position published since 1994). In 2002, the Bank of Slovenia revised the balance of payments statistics going back to 1994; the most significant revisions were related to the income component of the current account and to the other investment component of the financial account.

10. External Debt Statistics: External debt statistics were revised and brought in line with the SDDS in August 2003. The main change comprised the inclusion of trade credits in the debt data. 
REPUblic Of SLOVENIA: TABLE OF COMMON INDICATORS REQUIRED FOR SURVEILLANCE As OF MARCH 31, 2011

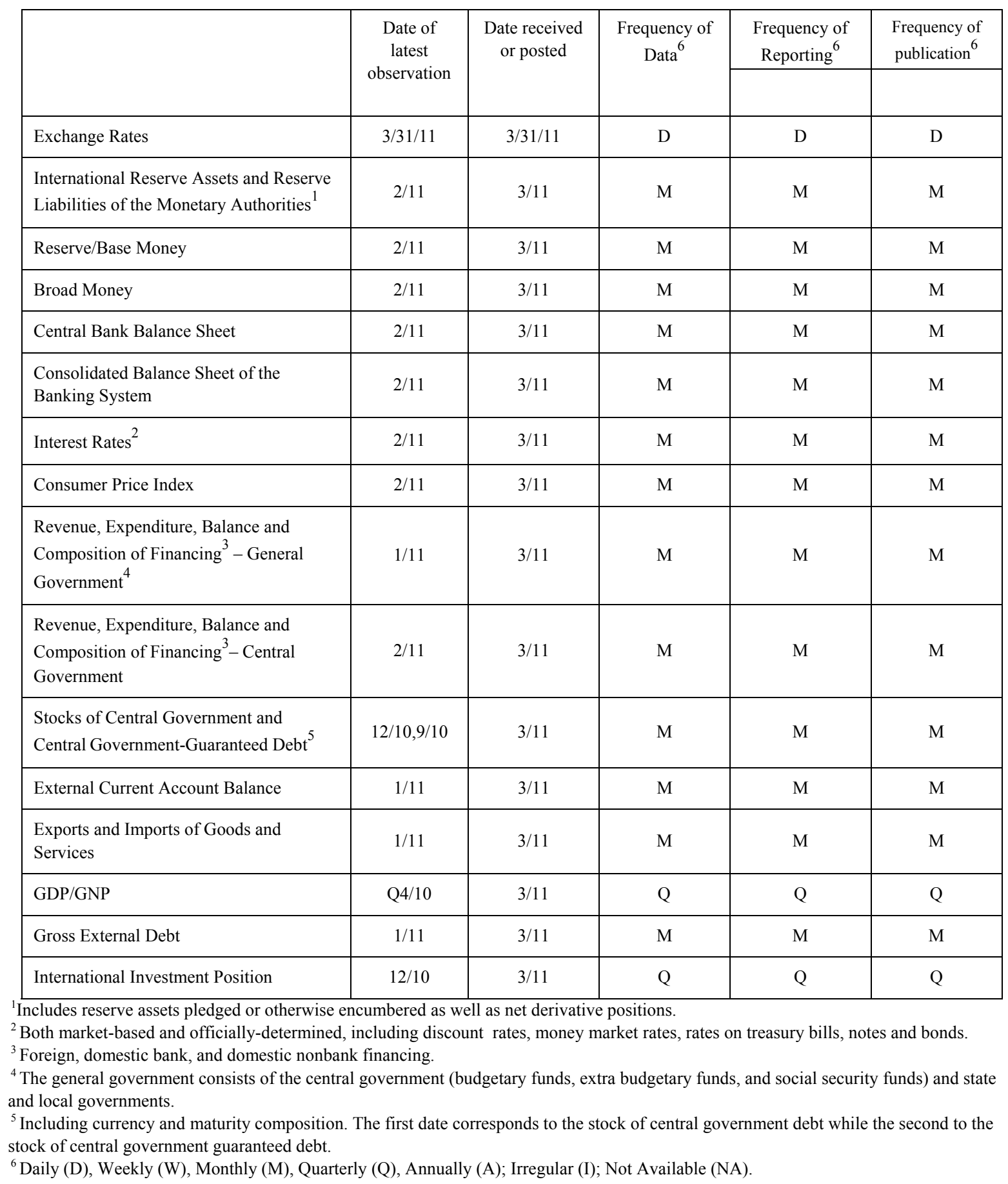




\section{INTERNATIONAL MONETARY FUND}

Public Information Notice

EXTERNAL RELATIONS DEPARTMENT
Public Information Notice (PIN) No. 11/66

FOR IMMEDIATE RELEASE

May 31, 2011
International Monetary Fund

$70019^{\text {th }}$ Street, NW

Washington, D. C. 20431 USA

\section{IMF Executive Board Concludes 2011 Article IV Consultation with the Republic of Slovenia}

On May 20, 2011, the Executive Board of the International Monetary Fund (IMF) concluded the Article IV consultation with the Republic of Slovenia. ${ }^{1}$

\section{Background}

Slovenia's economy is gradually recovering following one of the sharpest GDP declines in the euro area during the crisis. Real GDP declined over 10 percent from peak to trough owing to: a sharp decline in external demand; a significant tightening in external credit conditions forcing banks to curtail domestic credit supply; and an abrupt end of a construction and housing price boom. Real GDP growth reached 1.2 percent in 2010, led by rising exports. Weak domestic demand led to negative core inflation and greatly reduced the current account deficit. The current account deficit shrank from 6.7 percent of GDP in 2008 to 1.2 in 2010, reflecting mainly the end of the construction boom. Average CPI inflation was 1.8 percent in 2010, mainly because of rising fuel and energy prices. The average unemployment rate increased to 7.2 percent in 2010 up from 4.8 percent at end 2008.

GDP growth is projected at 2 percent in 2011. The pick-up in growth reflects mainly a recovery in the manufacturing sector and inventory rebuilding. However, investment will likely be low due to deleveraging in the highly indebted corporate sector. High unemployment and fiscal retrenchment will weigh on consumption growth. Average inflation is projected to gradually pick up on the back of high commodity prices. The current account deficit is expected to widen again

\footnotetext{
${ }^{1}$ Under Article IV of the IMF's Articles of Agreement, the IMF holds bilateral discussions with members, usually every year. A staff team visits the country, collects economic and financial information, and discusses with officials the country's economic developments and policies. On return to headquarters, the staff prepares a report, which forms the basis for discussion by the Executive Board. At the conclusion of the discussion, the Managing Director, as Chairman of the Board, summarizes the views of Executive Directors, and this summary is transmitted to the country's authorities. An explanation of any qualifiers used in summings up can be found here: http://www.imf.org/external/np/sec/misc/qualifiers.htm
} 
as the economy recovers, but not as much as in pre-crisis times. The main risks to the outlook are the near-term dependence of the recovery on external demand and significant contingent public liabilities from entitlement spending and banks. The postponement of pension and labor market reforms could also lead to further deterioration in competitiveness and potential output growth.

The general government fiscal deficit narrowed in 2010. After widening considerably during the crisis, the general government deficit declined to 5.2 percent in 2010. The main factors were one-off revenue gains, cuts in capital transfers, and containment of the wage bill. The deficit is expected to continue narrowing in 2011 primarily through further wage bill rationalizations, reduced indexation of pensions and other entitlements, and capital expenditure and capital transfer cuts. The authorities aim to reduce the fiscal deficit to below 3 percent by 2013. In the long term, pension expenditure poses a challenge to fiscal sustainability. Slovenia is projected to have one of the largest pension expenditures in the EU by 2050 if no reform is implemented. The authorities started addressing the challenge with the pension reform that will increase the effective retirement age and lower the replacement rate. But additional reforms will be needed to ensure sustainability of the system in the long run.

The crisis exposed vulnerabilities in the financial sector. The rapidly expanding credit growth financed with short-term external bank borrowing came to a sudden stop in 2008. Banks' profitability and asset quality deteriorated with aggregate profits turning negative in 2010 due to high loan losses to the highly indebted corporate sector. Total assets declined and corporate credit growth remained anemic. Slovenian banks are among the most thinly capitalized in the EU, particularly the systemic domestic banks. Publicly announced recapitalizations are sufficient to offset the accumulated losses of the last two years. But, given the thin capitalization at the eve of the crisis, they will not be sufficient to create new lending capacity.

\section{Executive Board Assessment}

Executive Directors noted that, inspite of the authorities' commendable policy response, Slovenia experienced one of the largest drops in output in the euro area. The domestic boom, fueled by easy external financing conditions and an expansionary fiscal policy, came abruptly to an end with the global financial crisis. While a gradual recovery is underway, important challenges remain. Directors emphasized the need to keep the recovery on track, safeguard the sustainability of public finances, enhance financial sector resilience, and strengthen competitiveness.

Directors supported the authorities' fiscal consolidation targets, but stressed the importance of specifying and implementing additional and durable consolidation measures. Social programs should be better targeted, and the planned reduction in public sector employment should be implemented. 
Directors emphasized the crucial role of pension reform. While the current reform is a step in the right direction, it will likely fall short in generating the needed savings in the long run. Directors considered that additional measures should include a more rapid increase in the effective retirement age and moving indexation gradually toward full-price indexation. Directors stressed the importance of a strengthened communication strategy to help build social consensus for reform. They also encouraged the authorities to prepare contingency measures in case of rejection of the pension reform.

Directors highlighted the risks associated with the thinly capitalized banking sector. The nearterm priority should be on further increasing banks' capital buffers, along with strengthened supervision. The recently completed recapitalizations for the systemic banks are a good start, but probably insufficient. Directors also encouraged further tightening of capital requirements to reinforce the recapitalizations. They considered expanding ownership to include private and foreign investors as a key measure to help address governance and risk management weaknesses, as well as to acquire additional capital. Directors encouraged the authorities to set out and implement clear divestment strategies for their ownership stakes in domestic banks.

Directors cautioned that lending activity should be monitored carefully, but not distorted with adhoc measures, such as the recently taken measure of taxing banks' balance sheets to incentivize borrowing by the over-indebted corporate sector. They encouraged the authorities to monitor housing price developments closely to prevent recent surges in mortgage lending from creating new imbalances. Directors welcomed the authorities' willingness to tighten prudential regulations if necessary.

To address the slowdown in the economy's growth potential and to boost competitiveness, Directors agreed that structural reforms in labor and product markets will play a crucial role. They viewed the loosening of labor market restrictions, phasing-out of wage indexation schemes, and eliminating of pay increases unrelated to productivity gains as key in helping reduce unemployment. Directors also encouraged the authorities to enhance competition in product and financial markets to foster foreign direct investment (FDI) inflows.

It is expected that the next Article IV consultation with Slovenia will be held on a 12-month cycle.

Public Information Notices (PINs) form part of the IMF's efforts to promote transparency of the IMF's views and analysis of economic developments and policies. With the consent of the country (or countries) concerned, PINs are issued after Executive Board discussions of Article IV consultations with member countries, of its surveillance of developments at the regional level, of post-program monitoring, and of ex post assessments of member countries with longer-term program engagements. PINs are also issued after Executive Board discussions of general policy matters, unless otherwise decided by the Executive Board in a particular case. The staff report (use the free Adobe Acrobat Reader to view this pdf file) for the 2011 Article IV Consultation with Slovenia is also available. 
Slovenia: Selected Economic Indicators, 2007-2012

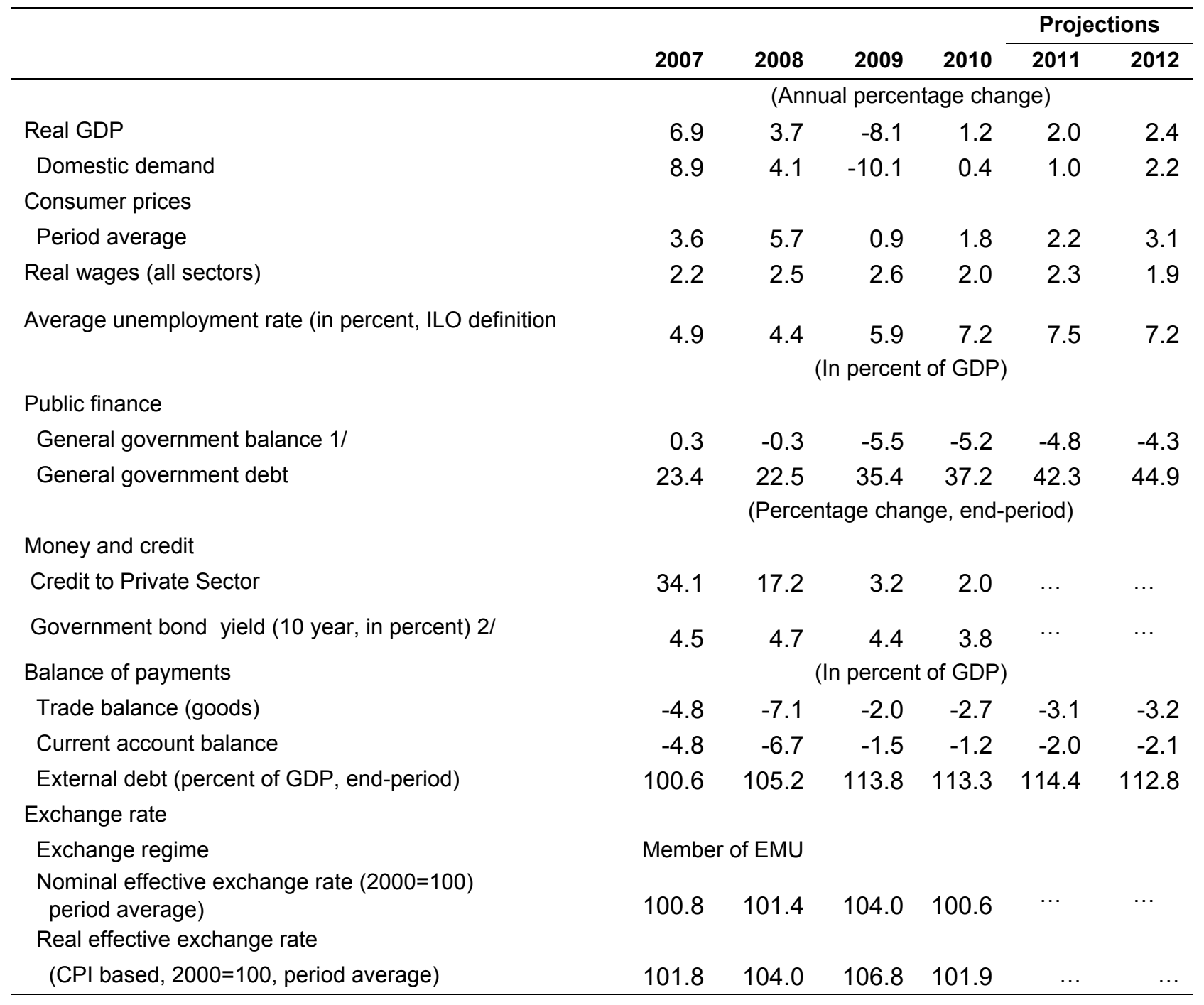

"Sources: Data provided by the Slovene authorities; and IMF staff calculations and projections" $1 /$ Revenue and expenditure exclude social security contributions paid for government employees. 2/ Eurostat data. 


\section{Statement by the IMF Staff Representative on Slovenia May 16, 2011}

1. This statement provides additional information on economic developments and policy action in Slovenia since the Article IV mission complementing the staff report (SM/11/92). The additional information does not change the thrust of the staff appraisal.

2. The announced state bank recapitalizations were completed. The government of Slovenia bought most of the 250 million euros in newly issued shares of Nova Ljubljanska Banka (NLB) at end March. The other large shareholder, KBC, bought less than 7 million euros. Similarly, Nova Kreditna Banka Maribor (NKBM), the second largest Slovenian bank, completed a capital increase of about 104 million euros at end April. The publicly owned electricity and postal companies bought 51 percent of the newly issued shares while the remainder was placed with private shareholders. After the recapitalizations, the overall governments' stake considering holdings by all publicly owned entities in NLB is estimated to have increased to 59 percent while the stake in NKBM remained unchanged at 51 percent.

\section{The recapitalizations will have a one off fiscal impact of about 0.7 percent of} GDP on the 2011 general government deficit. This fiscal impact is generated by the recapitalization of NLB. A decision from the European Commission adopted during April indicated that the funds used for NLB's recapitalization should be treated as state aid thus increasing the general government fiscal deficit for 2011. The authorities have already incorporated the 0.7 percent of GDP impact in their stability program, and given the one off nature, will not require offsetting measures. Unlike NLB's recapitalization, NKBM's recapitalization does not affect the general government deficit given that publicly owned companies not belonging to the general government purchased the shares.

4. The government approved a tax on bank assets. The government adopted in April a bill introducing a tax on total assets of banks. The tax was announced as a temporary measure. The need for the measure will be reassessed in 2013. Banks which are active in giving out loans to businesses will get certain incentives and could be exempt from the new tax. Those who are not exempt will have to pay tax in the amount of 0.1 percent of their total assets for the year. Given that the large state banks which dominate the banking system are likely going to benefit from the exemptions, the revenue yield from the tax is expected to be negligible.

5. The law on mini-jobs was overwhelmingly rejected in a referendum in early April and the referendum on the pension reform is scheduled for early June. The rejection by referendum will postpone the labor market reforms the mini jobs act was supposed to implement by at least one year given legal constraints to legislate again on the same topic before this time period. Current polls suggest that the pension reform is also likely to be rejected. 


\section{Statement by Johann Prader, Alternate Executive Director for Slovenia, and Andrej Kavcic, Advisor to the Executive Director for Slovenia \\ May 20, 2011}

We would like to thank staff for the fruitful and constructive dialogue during the 2011 Article IV mission to Slovenia. The Slovenian authorities broadly agree with staff's analysis and recommendations.

\section{Economic developments}

Even though Slovenia largely avoided the first wave of the financial crisis, it was severely hit when the crisis affected the real sector. As an export-dependent economy, Slovenia experienced a sharp GDP decline in 2009 (- 8.1 percent), which was aggravated by the concurrent phasing out of the national highway construction program. The sharp decline in external demand and curtailed credit supply weighed heavily on the highly leveraged corporate sector, particularly construction. Due to the relatively low debt-to-GDP ratio and solid household balance sheets Slovenia managed to avoid spillovers from the European sovereign debt crisis.

The crisis left a strong mark on the Slovenian economy. An export-led recovery is under way, but remains gradual. Whereas the export-oriented manufacturing sector is rebounding relatively fast, the recovery in other sectors is sluggish due to persistent high unemployment, a very low level of investment and weak domestic demand. The unemployment rate, which increased to 7.2 percent in 2010 , is expected to peak this year at 7.5 percent but is likely to start decreasing gradually in 2012 and thereafter. Against this background, GDP growth, which turned to a positive 1.2 percent in 2010, is estimated at 2.0 percent this year, although most international forecasters, including the OECD, the European Commission and staff tend to be somewhat more optimistic than the authorities' conservative approach. The relatively gradual economic recovery is heavily influenced by the continuous deleveraging in the construction sector, which was over-dimensioned before the crisis, and the relatively limited activity in the financial sector.

\section{Fiscal consolidation}

During the crisis fiscal policy turned countercyclical, with automatic stabilizers working and discretional stimulus measures amounting to 1.8 percent of GDP in 2009 and 0.2 percent in 2010, thereby increasing the deficit. After a moderate surplus in 2007 and a moderate deficit in 2008, the deficit widened to 5.5 percent of GDP in 2009 and 5.2 percent in 2010. The government has been continuing with the consolidation efforts in 2011 and targeted a reduction to 4.8 percent. However, the government's participation in the recapitalization of 
the systemic bank Nova Ljubljanska Banka (NLB) in the amount of EUR 243 million is increasing the deficit. The European Commission classified this participation as state aid (Commission Decision of March 8, 2011), thereby increasing the nominal deficit in 2011 by 0.7 percentage points higher (totaling 5.5 percent) than originally scheduled. Given that the measure is one-off, this move does not impact the underlying consolidation of the structural deficit.

The authorities are committed to bringing the fiscal deficit to below 3 percent of GDP by 2013. They find the staff scenario overly pessimistic, especially in view of Slovenia's proven track-record of better-than-budgeted outcomes. Under the government's exit strategy, all stimulus measures except subsidies for temporarily laid-off workers were phased out by the end of 2010. In line with the EU's Excessive Deficit Procedure (EDP), a program of gradually reducing the general government deficit to below 3 percent by 2013 was prepared. In light of the already relatively high tax burden, fiscal consolidation will be expenditurebased, primarily comprising measures in the area of wages, pensions and social benefits. Among the short-term measures, wage bill growth will be contained by the reduction in aggregate salary by 2.2 percent in nominal terms and non-indexation of wages to inflation in 2011 and 2012. The policy of reducing employment in the public sector by 1 percent annually will continue. To underpin the necessary fiscal consolidation an intervention act was passed for the 2011 budget implementation. The government is contemplating additional measures by means of a new intervention act to safeguard the deficit-reduction process.

To ensure sustainability of public finances in the long run, the government has embarked on fiscal structural reforms which include pension, health care and financial management reforms. The pension reform, which is crucial, was adopted by the Parliament in December 2010, and includes an increase in the minimum and full retirement ages (to 60 and 65, respectively), a gradual extension of the period for calculating the pension base from the 18 best consecutive years to 34 years, a change in the indexation of pension benefits and changes in the system of incentives. Unfortunately, the reform will be challenged in a referendum on June 5, 2011, and the outcome remains uncertain. Pending the outcome of the referendum, the government is designing contingency measures. One of the alternative measures is a temporary freeze of pensions and the immediate submission of a new proposal.

In the public financial management area, performance budgeting has been gradually introduced across all ministries. In addition, changes to the Public Finance Law are under way and are expected to be passed by the parliament not later than by the end of the year. They will introduce a medium-term budgetary framework (MTF), expenditure ceilings ("fiscal rule"), a debt ceiling of 45 percent of GDP, and a ceiling for all government guarantees. The new act will also further strengthen the responsibilities and accountability structure for the recently created fiscal council. 


\section{The financial system}

The global crisis exacerbated the weaknesses of the financial system characterized mainly by short-term external bank borrowing and over-indebted corporate sector. As a consequence, weakened banks are coping with declining profitability incurred by loan losses of the highly indebted non-financial corporate sector, especially construction and leveraged holding companies. Despite aggregate loan losses in 2009 and 2010, which were mainly due to very conservative provisioning, banks are expected to turn profitable (in aggregate) again in 2011.

The authorities are aware that Basel III will require higher capital ratios and concur with staff that strengthening capital buffers is necessary. In this context, the central bank has accelerated efforts to comply with Basel III. As the first step, the two largest banks, NLB and Nova kreditna Banka Maribor (NKBM) were recapitalized. The latest recapitalization of the systemically most important bank, NLB, will ensure a Tier 1 capital ratio of almost 8 percent, while the raising of additional capital will be explored as needed. In line with OECD recommendations and staff encouragement to ensure a greater role of private investors and to strengthen governance of the financial sector, the government adopted the Strategy for the Financial Sector Development in April 2011, as the first one in a series of sectoral strategies under preparation. The strategy advocates the creation of 3 financial pillars centered round the two largest banks (NLB and NKBM) and the largest insurance group, Triglav. While the state maintains shareholdings in all three financial groups, the Strategy envisages systematical divesting over time, whereby the state would limit its shareholding to 25 percent at the most. Following the OECD recommendations to delink state ownership in the companies from their management, an independent Capital Asset Management Agency was established. Besides managing the state assets in such companies and restructuring them for sale, the agency will prepare a recommendation on the disposal of non-strategic assets, based on sectoral strategies. In order to stimulate the credit activity of banks to the non-financial sector the government put forward a proposal for a tax on banks' assets, aimed at taxing all banks' assets while a tax allowance is introduced for banks which are expanding their credit activity. The draft legislation is currently discussed by the parliament with a view of enforcement by July 1, 2011.

\section{Structural issues}

The authorities agree with staff that maintaining competitiveness is crucial for Slovenia as a small and export dependent economy, especially due to the large share of labor-intensive products. In dialogue with the social partners, the government has been trying to introduce a greater level of flexible arrangements in the labor market and ensure prudent trends in the growth of unit labor costs. While consensus on increasing security can be quickly reached, 
increasing labor market flexibility has met with political resistance. As a consequence, the Mini-Jobs Act, regulating student work and aiming to contribute to increasing employment, was repealed in a referendum in April 2011. Reduction of regular workers' employment protection, in particular rapid reduction in notice periods and severance payments, recommended by staff, is being considered by the government along with other measures in the labor market. To enhance FDI attractiveness and boost productivity new initiatives are currently being considered to reduce and facilitate administrative procedures in starting new businesses, as well as to accelerate bankruptcy procedures, and potentially reduce social security contributions. 